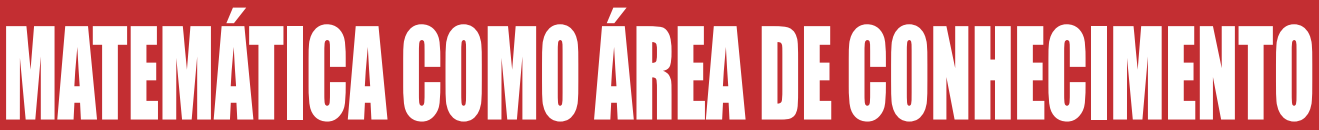

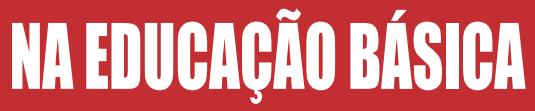

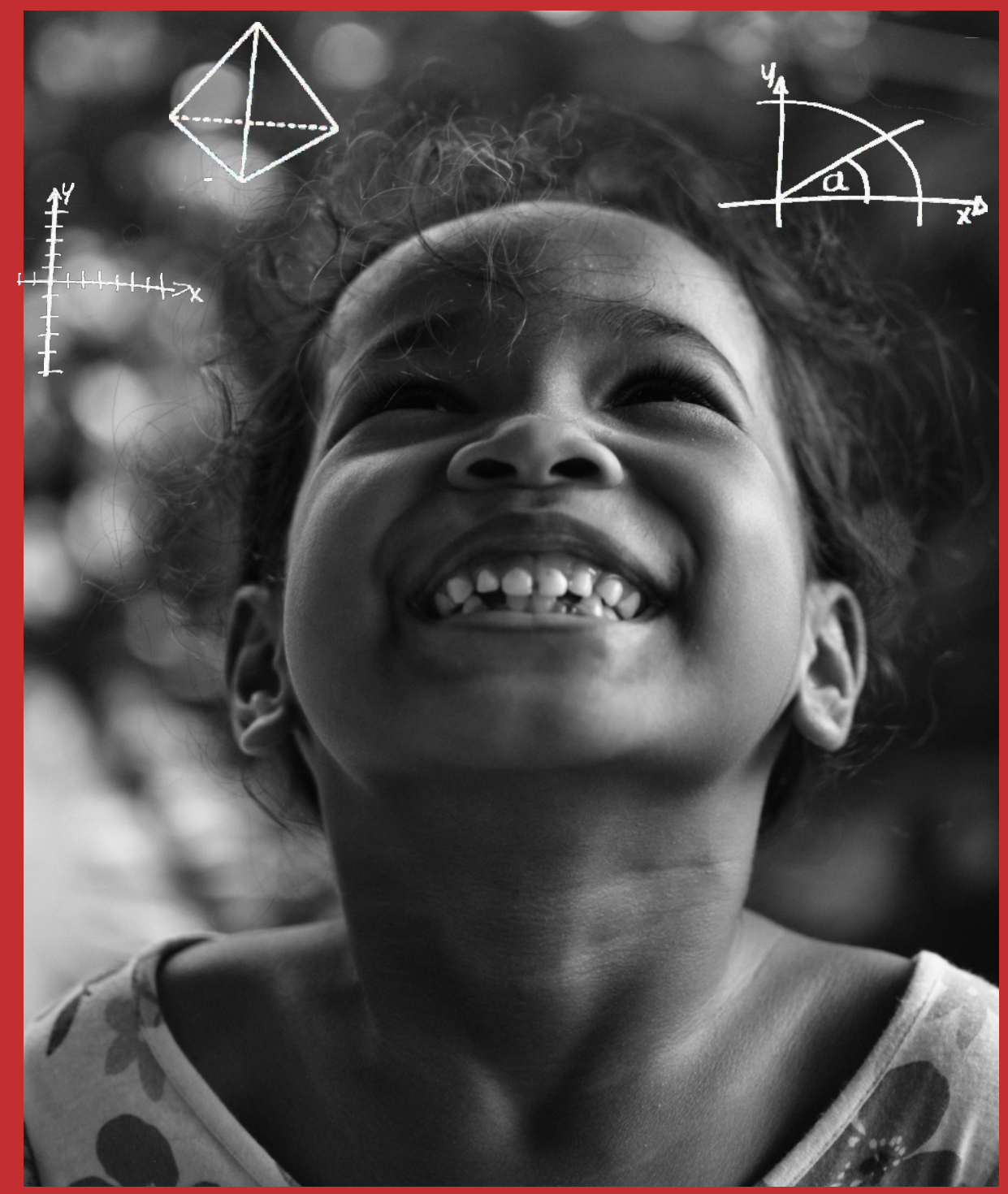

Adilison Dalhen [Org.]

Ana Lúcia Manniqure - Antônio Miguel - Gristina Gerri - Dario Fiorentini Luis Garlos de Menezes - Maria Helena de Souza - Migucel Rihloiro - Nillson José Machadio

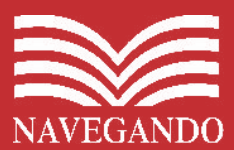





\section{MATEMÁTICA COMO ÁREA DE CONHECIMENTO NA EDUCAÇÃO BÁSICA}

$1^{\mathrm{a}}$ Edição Eletrônica 

Adilson Dalben

Organizador

\section{MATEMÁTICA COMO ÁREA DE CONHECIMENTO NA EDUCAÇÃO BÁSICA}

$1^{\text {a }}$ Edição Eletrônica

Uberlândia / Minas Gerais

Navegando Publicações

2019

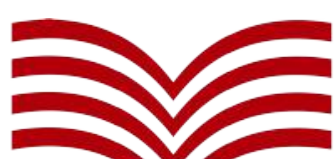

NAVEGANDO 


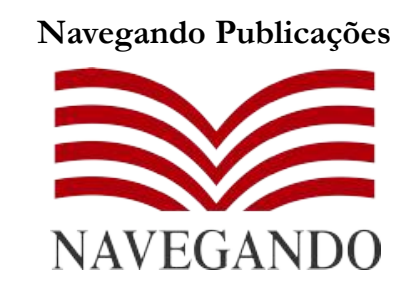

www.editoranavegando.com editoranavegando@gmail.com Uberlândia - MG, Brasil

Copyright (C) by autor, 2019.

M4254 - Dalben, Adilson. (Org.) Matemática como área de conhecimento na educação básica. Uberlândia: Navegando Publicações, 2019.

ISBN: 978-85-53111-95-4

do: $10.29388 / 978-85-53111-95-4-0$

1. Matemática 2. Educação Básica I. Adilson Dalben. II. Navegando Publicações. Título.

$$
\begin{array}{r}
\text { CDD }-370 \\
\text { CDU }-37
\end{array}
$$

Diagramação: Lurdes Lucena

Capa: Alberto Ponte Preta

Imagem da Capa: Imagem de dara nilrothanak por Pixabay

\section{Índice para catálogo sistemático}

Educação

370

Matemática

510 
Navegando Publicações

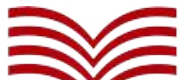

NAVEGANDO www.editoranavegando com editoranavegando@gmail.co

$\underline{\mathrm{m}}$

Uberlândia - MG Brasil

Pesquisadores Nacionais

Afrânio Mendes Catani - USP, Brasil

Anselmo Alencar Colares - UFOPA, Brasil

Carlos Lucena - UFU, Brasil

Carlos Henrique de Carvalho - UFU, Brasil

Cílson César Fagiani - Uniube, Brasil

Dermeval Saviani - Unicamp, Brasil

Elmiro Santos Resende - UFU, Brasil

Fabiane Santana Previtali - UFU, Brasil

Gilberto Luiz Alves - UFMS, Brasil

João dos Reis Silva Júnior - UFSCar, Brasil

José Carlos de Souza Araújo - Uniube/UFU, Brasil

José Claudinei Lombardi - Unicamp, Brasil

José Luis Sanfelice - Unicamp, Brasil

Lívia Diana Rocha Magalhães - UESB, Brasil

Mara Regina Martins Jacomeli - Unicamp, Brasil

Newton Antonio Paciulli Bryan - Unicamp, Brasil

Paulino José Orso - Unioeste - Brasil

Ricardo Antunes - Unicamp, Brasil

Robson Luiz de França - UFU, Brasil

Valdemar Sguissardi - UFSCar - (Apos.), Brasil

\section{Editores}

Carlos Lucena - UFU, Brasil

osé Claudinei Lombardi - Unicamp, Brasil

sé Carlos de Souza Araújo - Uniube/UFU, Brasil 



\section{SUMÁRIO}

APRESENTAÇÃO

Adilson Dalben

PARTE I - ELEMENTOS INICIAIS PARA ANÁLISE

ÁREAS DE CONHECIMENTO E FORMAÇÃO DE 9

PROFESSORES

Luis Carlos de Menezes

DISCIPLINAS OU ÁREAS DE CONHECIMENTO PARA QUÊ? POR

UMA FORMAÇÃO TERAPÊUTICO INDISCIPLINAR DE HUMANOS

PARA A VIDA E PARA SUAS FORMAS DE VIDA

Antonio Miguel

MATEMÁTICA, ÁREA DE CONHECIMENTO E EDUCAÇÃO

Maria Helena Soares de Souza

QUAL É O LUGAR DA MATEMÁTICA?

Cristina Cerri

A MATEMÁTICA COMO UMA ÁREA DO CONHECIMENTO

Nílson José Machado

ELEMENTOS CONSTITUINTES PARA UMA DISCUSSÃO SOBRE A

ÁREA DE CONHECIMENTO ENSINO DE MATEMÁTICA NA FORMAÇÃO DE PROFESSORES

Ana Lúcia Manrique

ESPECIFICIDADES DO CONHECIMENTO DO PROFESSOR COMO VEÍCULO QUE PERMITE TRANSCENDER AS FRONTEIRAS DA DISCIPLINA ESCOLAR ATÉ A ÁREA DE CONHECIMENTO Miguel Ribeiro

PARTE II - ELEMENTOS EM DEBATE PARA ANÁLISE

DESAFIOS PARA TRATAR O ENSINO DA MATEMÁTICA COMO

ÁREA DE CONHECIMENTO NA EDUCAÇÃO BÁSICA

DÚVIDAS, RESPOSTAS E DESAFIOS PARA A FORMAÇÃO DE 



\section{APRESENTAÇÃO*}

Adilson Dalben

Todo o material presente neste livro foi produzido para um evento realizado na Faculdade SESI-SP de Educação (FASESP) em outubro de 2016 e que teve por objetivo discutir as implicações e olhar para a Matemática como uma área de conhecimento na Educação Básica, tal como é a área de Linguagens, Ciências Humanas e Ciências da Natureza, extrapolando assim, a percepção de um componente curricular.

Com os resultados dessa discussão, esperou minimamente levantar novas questões que podem orientar o aprimoramento da organização curricular não só da Educação Básica, mas também, senão principalmente, de cursos de Licenciatura.

Em alguma medida, a proposição de uma organização curricular por áreas de Conhecimento está presente na Base Nacional Comum Curricular e no novo Currículo Paulista, no entanto, já está presente de longa data.

A Faculdade SESI-SP de Educação (FASESP) é uma instituição de ensino superior com a vocação de oferecer cursos de formação inicial e continuada de professores. Seus cursos de licenciatura têm algumas características distintivas, dentre as quais está o programa de Residência Educacional na qual o licenciando se insere desde o primeiro semestre de formação, a prática de ensino dentro dos componentes curriculares (além da prática de ensino "como componente curricular") ao longo dos quatro anos de duração do curso e a formação por área de conhecimento.

Nela são oferecidos quatro cursos de licenciatura: em Ciências da $\mathrm{Na}-$ tureza, em Ciências Humanas, em Linguagens e em Matemática. A escolha dessas áreas foi bastante influenciada pela divisão curricular presente na Educação Básica no período compreendido entre concepção da faculdade, em 2010, e o início de suas atividades que ocorreu com cursos de pós-graduação Lato Sensu em 2016 e graduação em 2017.

Essa divisão curricular está especificada no Art. $8^{\circ}$ das Diretrizes Curriculares Nacionais para o Ensino Médio (Resolução CNE/CEB 02/2012), quando é estabelecido que o currículo deveria ser organizado pelas seguintes áreas de conhecimento: Linguagens, Matemática; Ciências da Natureza e Ciências Humanas (BRASIL, 2012). Essas áreas tornam-se mais concretas em dois importantes avaliações de larga escala, o Exame Nacional do Ensino Médio (ENEM) e o Exame Nacional para Certificação de Competências de Jovens e Adultos (ENCCJA).

*DOI - 10.29388/978-85-53111-95-4-0-f.1-6 
Tal proposta de organização curricular é também assumida na rede de escolas da Educação Básica mantidas pelo SESI-SP, como estabelecido em seu Referencial Curricular,

A formação integral do estudante dentro dos paradigmas da contemporaneidade requer que as áreas de conhecimento (Ciências Humanas, Ciências da Natureza, Linguagens e Matemática) e os componentes curriculares a elas relacionados sejam trabalhados de forma articulada, complementar e convergente, estabelecendo necessárias interconexões entre os saberes de forma a romper com a fragmentação do conhecimento. É comum que os componentes curriculares, como tradicionalmente organizados na escola, forneçam visões parciais da realidade (SESI-SP, 2015, p. 36).

A princípio, a temática de uma organização curricular por áreas de conhecimento e a consequente proposta formativa parece ser inerente às áreas de Ciências da Natureza, Ciências Humanas e Linguagem, dada a lógica de agrupamento de diferentes componentes curriculares da Educação Básica, sendo, portanto, entendida como a constituição de um conjunto de componentes curriculares, com suas devidas articulações e especificidades. Na rede de escolas do SESI-SP, essa proposição pode ser percebida no seguinte verbete sobre interdisciplinaridade contido em seus Referenciais Curriculares.

Interdisciplinaridade - eixo básico da organização curricular, a abordagem interdisciplinar propõe a articulação entre as áreas de conhecimento e os componentes curriculares a elas relacionados. Não excluindo as especificidades dos componentes curriculares, estabelece conexões entre os saberes de forma a romper com a fragmentação do conhecimento, levando à consolidação de práticas, posturas e atitudes que se predisponham a olhar por diferentes perspectivas uma mesma questão. (SESI-SP, 2015, p. 235).

Essa ideia está presente também no âmbito nacional como consta do Parecer CNE/CEB no 11/2010.

Os conteúdos sistematizados que fazem parte do currículo são denominados componentes curriculares, os quais, por sua vez, se articulam às áreas de conhecimento, a saber: Linguagens, Matemática, Ciências da Natureza e Ciências Humanas. As áreas de conhecimento favorecem a comunicação entre os conhecimentos e saberes dos diferentes componentes curriculares, mas permitem que os referenciais próprios de cada componente curricular sejam preservados (BRASIL, 2010).

Mais recentemente, essa ideia toma forma na Base Nacional Comum Curricular para o Ensino Fundamental, ainda que de maneira muito sutil. 
Nas áreas que abrigam mais de um componente curricular (Linguagens e Ciências Humanas), também são definidas competências específicas do componente (Língua Portuguesa, Arte, Educação Física, Língua Inglesa, Geografia e História) a ser desenvolvidas pelos alunos ao longo dessa etapa de escolarização. (BRASIL, 2017, p. 28).

Como pode ser percebido, na Educação Básica, é vigente a ideia de ter a Matemática como um componente curricular, mas nesse contexto é apresentada como uma área de conhecimento.

Enfim, há implicações nessa mudança de categoria curricular? Se sim, quais são elas? Se não, por quê? Independentemente da reposta afirmativa ou negativa a essa pergunta, a formação de professores de Matemática deve estar conectada aos elementos que fundamentam a essas perguntas. Por isso, a Matemática como uma das áreas de conhecimento na organização curricular da Educação Básica é o tema abordado nesse livro.

Esses questionamentos foram trazidos para serem analisados no primeiro curso de pós-graduação Lato Sensu voltado para o ensino da Matemática desenvolvido na Faculdade SESI-SP de Educação e representados pela seguinte questão central: "Quais são as implicações no ensino ao se reconhecer a Matemática como área de conhecimento, ultrapassando os limites de uma disciplina escolar?".

Apesar ser recorrente há décadas o uso no Brasil do termo “áreas de conhecimento", nota-se ainda, a falta de maior clareza em sua conceituação.

Para fundamentar as possíveis respostas a essa questão, uma das estratégias usadas foi a realização no dia 29 de outubro de 2016 uma adaptação da dinâmica denominada Grupo de Observação e Grupo de Verbalização (GOGV) que contou com a participação de 6 professores-pesquisadores do ensino da matemática para o debate.

Nesta dinâmica, é constituído um grupo de verbalizadores (GV) que forma um círculo no interior do outro grupo (GO) que apenas observará e registrará o debate. $\mathrm{O}$ debate é fomentado por questões postas por um mediador que compõe o grupo de verbalizadores.

Nessa dinâmica, o grupo de verbalizadores foi composto pelos professores Dr. Nilson José Machado - USP, Dr. Antônio Miguel - UNICAMP, Dra. Cristina Cerri - USP, Dr. Miguel Ribeiro - UNICAMP, Dra. Maria Helena de Souza - PMSP e Dra. Ana Lúcia Manrique - PUCSP, que compuseram o grupo de verbalizadores e foram mediados pelo Prof. Dr. Adilson Dalben - FASESP.

O grupo de observadores foi composto pelos alunos e alunas dos cursos de pós-graduação Lato Sensu da Faculdade SESI-SP de Educação, seus professores e pelos elaboradores da primeira versão do Projeto de Curso de Licenciatura em Matemática. Participou também do grupo de observação, o prof. Dr. Dario Fiorentini - UNICAMP, como convidado especial para elaborar uma síntese final do encontro. 
Visando uma melhor fundamentação para a participação de todos na dinâmica, cada um dos seis professores-pesquisadores do grupo de verbalização elaborou um texto abordando elementos considerados relevantes à temática proposta e orientados pela questão central. Esses textos foram previamente distribuídos a todos os participantes da dinâmica.

O desenvolvimento do debate foi dividido em duas partes.

$\mathrm{Na}$ primeira delas, cada um dos membros do grupo de verbalização respondeu a duas perguntas elaboradas pelos alunos do curso de especialização no "Ensino da Matemática nos anos finais do Ensino Fundamental e no Ensino Médio". Essas questões foram também previamente enviadas aos professores pesquisadores. As perguntas foram:

1) Para o professor Miguel Ribeiro:

a) Quais são os conhecimentos especializados do professor de Matemática necessários para que o trabalho escolar transcenda as fronteiras da disciplina escolar? Como isso pode acontecer?

b) A necessidade de perseguir objetivos a médio e longo prazo, sustenta também a necessidade de que a formação de professores (inicial e continuada) que ensinam(rão) matemática (desde a Educação Infantil) tenha como foco o desenvolvimento desse conhecimento especializado. Como pode acontecer a formação ou "re-formação" dos profissionais da educação?

2) Para a Profa. Maria Helena de Souza:

a) Atualmente, está mais evidente que os direitos das crianças não estão sendo garantidos, dada a não aprendizagem frequentemente constatada, inclusive nas salas de aula. Essa afirmação permite inferir que alguém não está cumprindo o seu dever e que, certamente, não é a escolas e nem o professor. Afinal, ambos não têm, em geral, as condições para garantir as aprendizagens de seus alunos. Se a matemática enquanto disciplina já não está sendo garantida, uma proposta de enfoque como área de conhecimento, que aumenta a complexidade e a necessidade de recursos irá garantir?

b) Como problematizar ideias, conectá-las com a história da humanidade, sem reduzi-la a um tema transversal? Quais aspectos diferenciam a matemática desenvolvida na área do conhecimento da matemática desenvolvida como tema transversal?

3) Para a Profa. Cristina Cerri:

a) Reformas de programas de ensino e materiais para subsidiar os trabalhos dos professores "atravancam" o desenvolvimento da matemática como área do conhecimento. Como devem ser pensa- 
dos e elaborados os programas de ensino e materiais para que matemática seja desenvolvida como área do conhecimento e não recaia novamente na escolarização?

b) A avaliação é tema de grande discussão e de tabu nas escolas, sendo ainda, em sua maioria, classificatória e excludente (principalmente nos exames vestibulares). Como deve ser avaliação nas escolas ao se trabalhar com área de conhecimento? Nesse contexto, como ficariam os exames vestibulares, inclusive o ENEM? Essas avaliações poderiam ser um meio de força a adoção da matemática como área de conhecimento?

4) Para a Prof. ${ }^{a}$ Ana Lúcia Manrique:

a) Como organizar o trabalho nas escolas de Educação Básica para que ela realmente para que ela possa ser considerada uma área de conhecimento?

b) Essa organização do Ensino da Matemática a descaracterizaria como uma disciplina escolar? Um trabalho interdisciplinar na disciplina de matemática, não poderia ser considerado um ensino por área de conhecimento?

5) Para o Prof. Nilson José Machado:

a) É fato que a excessiva fragmentação e a falta de articulação entre os conteúdos em nossas escolas e sistemas de ensino. De que maneira desenvolver projetos, considerando a matemática como área do conhecimento, atendendo interesses dos alunos, atingindo expectativas de ensino e aprendizagem, sem instrumentalizá-la, sem empobrecer o uso corrente da língua e desconstruindo a fragmentação?

b) De todo o exposto e tratado nos textos, objetivamente, quais são os elementos que permitiriam classificar "algo" como "área de conhecimento"?

6) Para o Prof. Antônio Miguel:

a) Suas reflexões apontam para uma organização não disciplinar para a construção do Conhecimento. Em que medida o senhor acha exequível essa proposta considerando o atual contexto educacional (constituído historicamente)?

b) Um exercício de inversão de papéis: Se o senhor fosse atualmente responsável pela elaboração curricular de uma escola, de um município, de um estado ou do Brasil, qual seria a crítica que faria a seu texto? 
Na segunda parte, cada um dos verbalizadores pode fazer suas considerações finais, porém considerando a seguinte provocação metafórica, proposta pelo Prof. Dr. Luis Carlos de Menezes, para colocar um olhar para a formação de professores: "Se imaginarmos que cada uma das faces de um tetraedro representasse uma das áreas de conhecimento (Ciências da Natureza, Ciências Humanas, Linguagem e Matemática), cujo núcleo seria preenchido por cultura e práticas sociais, este sólido seria uma boa representação da proposta de formação dos profissionais da educação da Faculdade SESI-SP de Educação?”.

O trabalho do dia foi concluído com uma síntese feita pelo Prof. Dario Fiorentini.

Este livro é composto inicialmente por sete textos. No primeiro deles, do prof. Dr. Luis Carlos de Menezes que traz um panorama da organização curricular por Área de Conhecimento e pelos seis textos produzidos pelos professores-pesquisadores que participaram do grupo de verbalização.

Em seguida se encontra a transcrição das duas partes do debate, sendo que ao final da há fechamento feito pelo prof. Dr. Dario Fiorentini.

Enfim, é esperado que esta produção possa colaborar para a melhor formação de professores, para a melhor elaboração de tarefas de ensino e que os elementos conceituais aqui presentes possam iluminar a elaboração dos documentos curriculares.

\section{Referências:}

BRASIL. Ministério da Educação. Conselho Nacional de Educação. Câmara da Educação Básica. Resolução $\mathrm{CNE} / \mathrm{CEB} n^{\circ}$ 2, de 30 de janeiro de 2012. Institui as Diretrizes Curriculares Nacionais para o Ensino Médio. Diário Oficial da União, Brasília, DF, 31 jan. 2012

Ministério da Educação. Conselho Nacional de Educação. Parecer CNE/CEB n. 11/2010, de 7 de julho de 2010. Sobre as Diretrizes Curriculares Nacionais para o Ensino Fundamental de 9 anos. Brasília, DF: CNE/CEB, 2010.

.Ministério da Educação. Secretaria da Educação Básica. Base nacional comum curricular. Brasília, DF, 2017.

SESI-SP. Serviço Social da Indústria. Referencial Curricular: Ensino Fundamental / Serviço Social da Indústria (SESI-SP). -- 1.ed. -- São Paulo: SESISP Editora, 2015. 


\section{PARTE I \\ ELEMENTOS INICIAIS PARA ANÁLISE}





\title{
ÁREAS DE CONHECIMENTO E FORMAÇÃO DE PROFESSORES
}

\author{
Luis Carlos de Menezes
}

Como uma formação em áreas de conhecimento pode preparar melhor professores para cada componente curricular da Educação Básica?

\section{As áreas de conhecimento}

As Áreas de Conhecimento na Educação Básica, tanto quanto a correspondente formação de professores, tem tido um longo histórico, em que a afirmação de sua necessidade tem sido contraditada ou postergada, seja por cautela da academia, seja pela tradição escolar de componentes disciplinares estanques. Há quase meio século, propostas de formação docente combinada, como "Estudos Sociais" e licenciaturas afins, foram combatidas pelas universidades por temor de que levasse a precarização formativa. E mesmo quando, há duas décadas, os Parâmetros Curriculares Nacionais reuniram os componentes curriculares em áreas, estas não foram realmente efetivadas na organização curricular da maior parte das escolas brasileiras.

De fato, as áreas da educação escolar não têm correspondência clara no âmbito acadêmico, onde se distinguem ciências da natureza de ciências humanas, mas filosofia e matemática usualmente não se identificam como ciências, e onde as línguas e literaturas correspondem a "Letras", e nem Arte nem Educação Física se identificam com uma Área de Linguagens. Por isso, as quatro Áreas do Conhecimento, hoje estabelecidas na Educação Básica, precisam ser compreendidas em seu contexto e sua defesa como recurso de estruturação formativa não pode ignorar os percalços já experimentados.

No Ensino Fundamental, História e Geografia são as ciências humanas, as Ciências Naturais e Matemática se aprendem em componentes únicos, e as linguagens envolvem Português, Arte e Educação Física, nos primeiros anos, e também Língua Estrangeira Moderna, nos anos finais. Há ainda o Ensino Religioso que, não sendo confessional, poderia ser tomado como parte das ciências humanas.

No Ensino Médio, a organização tem mais componentes e, pelo menos formalmente, as Áreas de Conhecimento já se apresentam: a Biologia, a Física e a Química compõem a Área de Ciências Naturais; a Área de Linguagens é composta por Português, Língua Estrangeira Moderna, Arte e Educação Física; à Área de Ciências Humanas, além de História e Geografia, acrescenta-se Socio-

${ }^{*}$ DOI - 10.29388/978-85-53111-95-4-0-f.9-14 
logia e Filosofia; a Matemática é Área autônoma, como no Ensino Fundamental.

O que dá sentido à Área de Linguagens é reunir as diferentes acepções das formas de expressão: idiomas, artes, linguagens corporais e esportes, ou seja, algo como as "linguagens da mente e do corpo". Sua constituição em "Área" é um recurso importante para organizar e estruturar a aprendizagem escolar, mesmo considerando que outros componentes, como a Matemática, igualmente possuem caráter ou dimensões de linguagem.

Vale a pena também ilustrar como a Matemática, tradicionalmente identificada como componente, veio a tornar-se Área. Quando, com base no antigo Exame Nacional do Ensino Médio (ENEM), foi elaborado o Exame Nacional de Certificação da Educação de Jovens e Adultos (ENCEJA), a Matemática surgiu neste como área autônoma. E essa autonomia se consolidou quando, por sua vez, um novo ENEM foi organizado com base no antigo ENCEJA. Tal status da Matemática é bem-vindo dado seu peso formativo, sendo que seus ramos, como cálculo, geometria, álgebra e probabilidades, podem ser tomados como seus componentes.

Foram assim estabelecidas, para a Educação Básica, as áreas de Ciências da Natureza, Ciências Humanas, Linguagens e Matemática, que poderiam ser visualizadas como as quatro faces de um tetraedro, em cujo interior estariam a cultura e as práticas sociais desenvolvidas na escola, e cada uma das faces seriam as "janelas" ou "lentes" através das quais a escola observa e se relaciona com o mundo. A Base Nacional Curricular Comum está sendo organizada nessas quatro áreas, em toda a Educação Básica, sendo de se esperar que tal organização se mantenha na sua terceira versão, em elaboração e a ser referendada pelo Conselho Nacional de Educação, a quem cabe estabelecê-las como norma nacional.

A organização em Áreas é, portanto, um recurso da educação básica em que a reunião e articulação de componentes não significa sua fusão. Há países de bom desempenho educacional, como a Finlândia, que projetam organizar toda a educação básica em Áreas do Conhecimento, diminuindo o número de componentes curriculares e integrando as disciplinas sem dissolvê-las. No Brasil, essa organização talvez não se apresente como orientação geral em curto prazo. Mas nada impede que venha a ser adotada por sistemas escolares que disponham de professores com formação por área. Levando em conta a condição brasileira, uma formação de professores em uma Área de Conhecimento deve prepará-los para conduzir o ensino do conjunto e de cada um dos seus componentes, dando-lhes mais significado em sua articulação conceitual.

\section{Porque e como formar professores em áreas de conhecimento}

No Ensino Fundamental, são oito os componentes curriculares regulares, e no Ensino Médio são treze, vários deles só dispondo de duas horas de 
aula por semana, e alguns só de uma. Há professores que conduzem um único componente, e só completam sua carga horária semanal atendendo duas dezenas de turmas, com muitas centenas de alunos cujas características não chegam a conhecer e, se trabalharem em várias escolas, sacrificam horas se deslocando entre elas. Se conduzissem três ou quatro componentes de uma área, passariam a conhecer melhor seus estudantes, em número três ou quatro vezes menor, trabalhariam em uma única escola, cujo projeto pedagógico efetivamente viveriam, e reduziriam seu tempo diário de deslocamento.

Só isso justificaria uma formação por área, múltipla e articulada. Mas essa só uma das suas vantagens e talvez não a mais expressiva: professores com formação numa Área de Conhecimento podem ser educadores mais amplamente preparados para conduzir cada um dos componentes, e habilitados para lecioná-los. Professores preparados para todos os componentes de uma área serão capazes de fazer correlações essenciais que enriquecem a aprendizagem de cada um deles. A energética celular seria mais amplamente compreendida numa aula de Biologia, se explicitadas as transformações físicas e químicas envolvidas. Gêneros musicais, teatrais e de artes visuais seriam mais eficazmente caracterizados em Arte, se tratados em contextos sociais e conjuntamente com períodos literários, ligando-os ao aprendizado de Português e de uma Língua Estrangeira. A Matemática vivida como área eliminaria o confinamento entre seus componentes e destes com as demais áreas para as quais são, ao mesmo tempo, linguagem e instrumental. Mudanças sociais na Europa, quando da transição da produção artesanal para a industrial, são temas que podem interligar aulas de História e Sociologia, dando contexto para a Geografia econômica mostrar por que razões semelhantes a América do Sul, hoje exportadora de commodities, foi antes colonizada. E isso tudo seria ingrediente para um filosofar sobre a condição humana no mundo globalizado da sociedade pós-industrial.

Resta mostrar, então, como é possível formar professores em Áreas de Conhecimento, sem aligeirar sua formação e sem precisar mantê-los toda uma década na faculdade, ou seja, sem multiplicar por três (ou por quatro) as típicas 3.200 horas demandadas para a formação em cada componente. O que permite reunir em uma Área seus vários componentes é exatamente o que esses têm em comum, como a investigação e quantificação nas Ciências da Natureza, a variedade de formas de expressão nas Linguagens, a evolução social e econômica nas Ciências Humanas, ou as relações entre funções, modelagens e probabilidades na Matemática. Precisamente esses traços comuns entre os componentes permitem associá-los em uma formação conjunta, ampliando sim os tempos formativos, mas sem precisar multiplicá-los.

Os aspectos afins dos componentes de cada área poderão ser apreendidos vantajosamente em conjunto, como princípios e conceitos gerais, objetos de conhecimento, métodos de investigação, recursos instrumentais materiais e virtuais, critérios de verificação, assim como aspectos históricos e filosóficos dos componentes e de seu ensino: a sucessão de períodos na literatura e nas ar- 
tes em geral; a história e a epistemologia das ciências da natureza e, em todas essas, a conservação e as transformações da energia; os aspectos sociológicos e filosóficos da ocupação e exploração de territórios e recursos naturais ao longo das etapas históricas. Quanto à Matemática, pensá-la como Área amplia sua responsabilidade de interlocução com as demais Áreas como modelagem ou linguagem, assim como atribui maior ênfase a cada um dos seus componentes.

Mas há muitos outros ganhos, ao combinar a economia de tempo com o ganho de qualidade, quando levamos em conta a formação pedagógica dos professores de cada área. Há aspectos que são praticamente universais, que naturalmente serão comuns não somente a uma Área, mas também a todas as Áreas, como didática geral, cultura e organização escolar, psicologia dos estudantes de cada faixa etária, história da educação no Brasil e no mundo. Acrescente-se a isso que as didáticas específicas também são muito próximas no interior de cada Área, de maneira que a formação para didática das Ciências Naturais, das Linguagens, das Ciências Humanas e da Matemática, pode sem conduzida em cada Área, sem sacrificar a qualidade ou até mesmo a ampliando.

Nada poderia justificar, no entanto, a ausência de uma formação específica e mais aprofundada em cada componente da Área, mas nem por isso precisam ser "multiplicadas" a preparação pedagógica geral, a preparação pedagógica específica de Área e parte da formação conceitual partilhada entre os componentes de cada Área. Consideradas essas dimensões comuns, as três mil e duzentas horas estipuladas para a formação de cada componente na faculdade deverão dar lugar a quatro mil e tantas horas na formação em Área, correspondendo há cerca de quatrocentas horas suplementares para cada novo componente agregado.

É preciso ressaltar, no entanto, serem inegociáveis a qualidade e a extensão dos estágios formativos, ou de "residência escolar", em que os licenciandos entrarão em contato com a cultura escolar e, especificamente, com a aprendizagem escolar de cada um dos componentes para os quais eles serão habilitados. Esse aspecto não comporta simplificação e será preciso sim multiplicar as horas: tantas vezes o número de horas prescritas de estágio ou residência quantos sejam os componentes contemplados na Área. Noutras palavras, os estágios devem garantir intimidade no trabalho disciplinar de cada componente, com vivência em classes de cada um deles, além da vivência escolar em sentido amplo, para o que será essencial uma articulação orgânica entre centros formadores e sistemas escolares.

Toda essa argumentação pretende valer para qualquer modalidade de Educação Básica. No entanto, tendo-se em vista a hoje discutida diversificação do Ensino Médio, para além da modalidade propedêutica reforçada pela designação "Médio", é interessante cogitar que outro sentido poderia ter a formação em Áreas nas modalidades voltadas à preparação para o trabalho. Nessas outras versões do Ensino Médio, hoje pode chegar a cerca de duas dezenas o número de componentes curriculares, pelo acréscimo daqueles que qualificam para o 
exercício profissional. Isso recomendaria um número menor de componentes disciplinares, circunstância que leva a pensar em componentes de caráter realmente múltiplo, para os quais os professores formados por Área estariam igualmente qualificados.

\section{Onde formar professores em áreas de conhecimento}

Uma questão que decorre do conjunto das opções conceituais e metodológicas sinalizadas ao longo deste texto tem a ver com quais instituições poderiam e se disporiam a formar professores em Áreas de Conhecimento. Universidades conceituadas têm a formação de licenciados de cada componente em paralelo ou em sequência à de bacharéis e suas Unidades de Educação ou de Pedagogia usualmente dão sua contribuição em separado das demais Unidades. Seria demandado um esforço considerável nessas instituições, envolvendo várias Unidades com sua relativa autonomia universitária, para promover uma formação múltipla e integrada. Considerando que nessas Unidades a maior parte dos formadores de professores para cada componente é de pesquisadores de uma temática específica seria essencial orientação e apoio para seu envolvimento educacional interdisciplinar. Também por isso, seria recomendável uma mobilização institucional e eventual aporte de recursos para promover tal esforço.

Há universidades particulares e faculdades isoladas, com maior flexibilidade na organização de novos cursos, mas nas quais as dificuldades a serem enfrentadas são de outra natureza. É compreensível que, atualmente, elas privilegiem certas licenciaturas e não outras, em função de demanda de mercado ou de custo formativo. Mas como são elas as responsáveis pela formação de boa parte dos professores em muitas regiões do Brasil, seu condicionamento ao mercado contribui para a carência de professores de certas especialidades. O envolvimento dessas instituições em formação por área deve ser apoiado, estimulado e também monitorado, fomentando e mesmo subsidiando a formação em Áreas, que responda às necessidades dos sistemas escolares em cada região. Contudo, cuidados devem ser tomados para evitar que venham a aligeirar essa formação, em função de custos, acenando para falsas vantagens de uma certificação múltipla, desprovida da efetiva qualificação.

Por isso tudo, será preciso promover e fomentar instituições públicas e privadas, que enfrentem o desafio de conceber e pôr em prática a Formação de Professores em Áreas, com qualidade acadêmica, esmero pedagógico e de forma articulada com as escolas de educação básica de seu entorno regional. Tratase de estabelecer políticas públicas coordenadas para esse propósito, o que envolve regulamentação legal, ampla difusão das novas modalidades, assim como mobilização de recursos materiais, humanos e institucionais. Vale enfatizar que a defesa que o presente texto faz da formação de professores em Áreas de Conhecimento converge com a demanda por uma regulamentação de formações 
interdisciplinares, expressa nas Diretrizes Curriculares Nacionais de Formação de Professores. 


\section{DISCIPLINAS OU ÁREAS DE CONHECIMENTO PARA QUÊ? POR UMA FORMAÇÃO TERAPÊUTICO INDISCIPLINAR DE HUMANOS PARA A VIDA E PARA SUAS FORMAS DE VIDA*}

Antonio Miguel

O foco temático da discussão que realizo neste texto tem como pano de fundo a preocupação que vem se manifestando entre professores e gestores dos cursos de graduação e pós-graduação Lato Sensu da Faculdade de Educação SESI-SP, sobretudo em torno da questão relativa às implicações, no ensino, do reconhecimento da Matemática como uma área autônoma de conhecimento, ultrapassando, porém, os limites de uma disciplina escolar. Dado, entretanto, que esta referida instituição educativa iniciou suas atividades de graduação, em 2017, com a oferta de quatro cursos de licenciatura organizados por "áreas de conhecimento" - Ciências da Natureza, Ciências Humanas, Linguagens e Matemática -, optei por ampliar o foco temático desta discussão situando-o no interior de um debate acadêmico mais amplo que vem se processando, já há algum tempo, em torno da pertinência política, epistemológica e pedagógica de se continuar investindo em políticas educativas e formativas de natureza estritamente epistemológica, em que "o conhecimento" se mostre compartimentado em disciplinas ou áreas autônomas diferenciadas. Mas, falar assim "do" conhecimento, como uma categoria supostamente autônoma, universal, abstrata e manejável, já não seria um efeito impertinente de uma incurável doença epistemológica?

Em uma das vezes em que me envolvi em um debate semelhante a este foi no ano de 2006, em uma fala numa das seções coordenadas da 29a Reunião Anual da ANPEd ${ }^{1}$. Tal fala, posteriormente publicada sob o título Áreas e subáreas do conbecimento, vinculos epistemológicos: o GT de Educação Matemática da ANPEd (MIGUEL, 2008), havia sido produzida sob o pano de fundo do questionamento ${ }^{2}$, por parte dos integrantes do Grupo de Trabalho de Educação Matemática, do "lugar epistemológico" no qual este GT havia sido alocado na estrutura científico- epistemológica organizacional da ANPEd, baseada em um alegado critério de "afinidades epistemológicas" entre áreas e subáreas de conhecimento, então em funcionamento, para se dar conta da avaliação, emissão de pareceres

\footnotetext{
*DOI - 10.29388/978-85-53111-95-4-0-f.15-42

1 Associação Nacional de Pós-graduação e Pesquisa em Educação.

2 Tal questionamento baseava-se no argumento dos frágeis laços de "afinidade epistemológica" entre os GTs da ANPEd que, naquela ocasião, integravam a subárea na qual também se inseria o GT de Educação Matemática, quais sejam: o GT de Educação e Sexualidade Humana, o GT de Educação e Afrodescendentes e o GT de Educação e Comunicação.
} 
circunstanciados, julgamento e seleção de trabalhos submetidos aos eventos científicos da Associação.

Por julgá-lo pertinente à discussão que vamos aqui desenvolver, quero retomar aqui, daquela minha fala, um aspecto da polêmica que o filósofo pragmático estadunidense Richard Rorty travou com o cientista também estadunidense Edward O. Wilson, o pioneiro dos estudos em sociobiologia e biodiversidade, em uma resenha publicada por Rorty, em 1998, sobre um livro de Wilson intitulado Consiliência: a unidade do conbecimento, no qual o biólogo defendia a tese de que seria:

[...] um erro pensar que existem inúmeros tipos de explicação apropriadas às perspectivas das disciplinas individuais, pois existe, intrinsecamente, apenas uma classe de explicação que atravessa as escalas de tempo e de complexidade para unir os fatos díspares das diferentes disciplinas por meio da concordância, da percep̧cão de uma rede inconsútil de causas e efeitos (WILSON, 1999, p. 257, itálicos nossos).

Recusando-se a estabelecer uma relação especular entre a defesa da segmentação disciplinar do conhecimento e a crença de que todos os fenômenos "naturais" e "culturais" estariam organizados em uma rede inconsútil - isto é, sem costura, sem emendas, feita de uma só peça - de causas e efeitos, cuja explicação poderia ser reduzida a um pequeno número de leis naturais fundamentais - Rorty argumentou do seguinte modo contra a tese da consiliência de Wilson:

Por que uma rede inconsútil de causas e efeitos acarretaria a possibilidade ou a desejabilidade de uma rede explicativa também inconsútil? Para nós, pragmatistas, pode e deve haver milhares de formas de descrever as coisas e as pessoas - tantas quantos forem os propósitos que tivermos em relação às coisas e às pessoas. Mas essa pluralidade não é problemática, não suscita problemas filosóficos e nem fragmenta o conhecimento. As disciplinas acadêmicas não são e nem devem ser reflexos do mundo real. Devem, sim, propiciar as maneiras de fazer as coisas no mundo real, de tecer a grande rede inconsútil das causas, de modo que os objetivos humanos sejam alcançados. A realidade é uma, mas as descrições dela são incontáveis [...], porque os seres humanos têm e devem ter objetivos diversos. Não devemos arrancar os cabelos por nossa infortunada cultura desunida. Não devemos eliminar as barreiras entre as disciplinas. Aliás, duvido da existência dessas barreiras (RORTY, 1998, p. 7-8, itálicos nossos).

Como se nota, embora Rorty defenda que a nossa "cultura acadêmica disciplinar desunida" deva colaborar para se "tecer a grande rede inconsútil das causas no mundo real", tal cultura disciplinar não é e nem deveria ser vista como o reflexo dessa rede inconsútil. Mas ainda que, por um lado, possamos discordar de Wilson acerca da possibilidade de se fornecer uma explicação cien- 
tífico-naturalista unitária, redutora e fundamentalista do modo como se tece tal suposta rede inconsútil - ou, até mesmo, discordar do suposto caráter unitário dessa própria rede que preexistiria antes e independentemente de suas próprias descrições humanas -, e ainda que, por outro lado, possamos concordar com Rorty acerca da possibilidade de uma diversidade incontável de descrições disciplinares não especulares dessa suposta rede, em função da variabilidade dos propósitos humanos orientadores dessas descrições, é possível também questionar a ambos sobre a manutenção da doença dualista explicativa ou descritiva que opõe, de um lado, uma "natureza" - quer una quer múltipla - passível de ser explicada ou descrita por humanos que não se veem parte dessa natureza e, de outro, uma "cultura científica" - disciplinarmente organizada ou não - que se supõe dotada do poder imperialista de fornecer descrições ou explicações unilaterais de uma "natureza" vista como "não humana", unicamente com base em propósitos ditos "humanos". Se decidi aqui dar destaque a um tal tipo de crítica, dentre outras que poderiam ser remetidas tanto ao ponto de vista de Wilson quanto ao de Rorty, é porque, contemporaneamente, a discussão do problema acerca da pertinência ou não de políticas de configuração disciplinar ou interdisciplinar do conhecimento - quer ao nível das investigações científico-acadêmicas, quer ao nível da formação escolar básica ou superior - vem se processando no quadro mais abrangente do debate ainda estritamente acadêmico relativo às relações entre "natureza" e "cultura". Vamos, então, dar a palavra a um dos destacados protagonistas desse debate mais abrangente, no cenário internacional atual, o antropólogo, sociólogo e filósofo da ciência francês, Bruno Latour ${ }^{3}$ :

Na página quatro do jornal, leio que as campanhas de medidas sobre a Antártida vão mal este ano: o buraco na camada de ozônio aumentou perigosamente. Lendo um pouco mais adiante, passo dos químicos que lidam com a alta atmosfera para os executivos da Atochem e Monsanto, que estão modificando suas linhas de produção para substituir os inocentes clorofluorcarbonetos, acusados de crime contra a ecosfera. Alguns parágrafos à frente, é a vez dos chefes de Estado dos grandes países in dustrializados se meterem com química, refrigeradores, aerossóis e gases inertes. Contudo, na parte de baixo da coluna, vejo que os meteorologistas não concordam mais com os químicos e falam de variações cíclicas. Subitamente, os industriais não sabem o que fazer. Será preciso esperar?

\footnotetext{
${ }^{3}$ Bruno Latour é professor do Instituto de Estudos Políticos de Paris. Foi um dos fundadores do campo de investigação denominado Estudos Sociais da Ciência e Tecnologia (ESCT) e um dos coautores da denominada Teoria-do-Ator-Rede ou Actor-Network-Theory (ANT). Foi intencional, por parte de Latour, abreviar o nome de tal teoria pela sigla ANT que, em inglês, forma a palavra significativa "formiga". Na nota dedicatória aos estudantes de doutorado que aparece em seu livro originalmente intitulado Reassembling the Social: An Introduction to Actor-Network-Theory (Latour, 2008), ele coloca dois quadrinhos. No primeiro desses quadrinhos, uma das personagens, dirigindo-se à outra, diz: "No capítulo sexto do Livro dos Provérbios se diz: "Vá até a formiga, preguiçoso! Observe as suas andanças e você se tornará sábio!”. No segundo quadrinho, a outra personagem responde à primeira: "Eu já fui. Mas ela também não sabia a resposta".
} 
Já é tarde demais? Mais abaixo, os países do Terceiro Mundo e os ecologistas metem sua colher e falam de tratados internacionais, direito das gerações futuras, direito ao desenvolvimento e moratórias. O mesmo artigo mistura, assim, reações químicas e reações políticas. Um mesmo fio conecta a mais esotérica das ciências e a mais baixa política, o céu mais longínquo e uma certa usina no subúrbio de Lyon, o perigo mais global e as próximas eleições ou o próximo conselho administrativo. As proporções, as questões, as durações, os atores não são comparáveis e, no entanto, estão todos envolvidos na mesma história. [...] Contudo, ninguém parece estar preocupado. As páginas de Economia, Política, Ciências, Livros, Cultura, Religião e Generalidades dividem o layout como se nada acontecesse. O menor vírus da AIDS nos faz passar do sexo ao inconsciente, à África, às culturas de células, ao DNA, a São Francisco; mas os analistas, os pensadores, os jornalistas e todos os que tomam decisões irão cortar a fina rede desenhada pelo vírus em pequenos compartimentos especificos, onde encontraremos apenas ciência, apenas economia, apenas representaçôes sociais, apenas generalidades, apenas piedade, apenas sexo. Aperte o mais inocente dos aerossóis e você será levado à Antártida, e de lá à universidade da Califórnia, em Irvine, às linhas de montagem de Lyon, à química dos gases nobres, e daí, talvez, até a ONU, mas este fio frágil será cortado em tantos segmentos quantas forem as disciplinas puras: não misturemos o conbecimento, o interesse, a justiça, o poder. Não misturemos o céu e a terra, o global e o local, o bumano e o inumano. "Mas estas confusões criam a mistura - você dirá -, elas tecem nosso mundo?" - "Que sejam como se não existissem", respondem os analistas, que romperam o nó górdio com uma espada bem afiada. O navio está sem rumo: à esquerda o conhecimento das coisas, à direita o interesse, o poder e a política dos homens (LATOUR, 2013, p. 7-8, itálicos nossos).

Quando olhamos para as dicotomias correlacionadas entre, por um lado, "natureza versus cultura" e, por outro, entre "humanos versus não humanos", sob o aspecto de uma suposta possibilidade de existência independente ou autônoma de formas "culturais" de vida humana relativamente a outras formas "naturais" de vida, o "construcionismo" latouriano - pós-moderno e pós-antropocêntrico, porque ciente da razoabilidade da perspectiva animista que caracteriza o "pensamento selvagem" dos povos indígenas, tal como lhe foi sugerida pela seguinte passagem da obra de Lévi-Strauss - também nos aparece como legítimo e sustentável:

Um observador exótico julgaria, sem dúvida, que a circulação automobilística no centro de uma grande cidade ou em uma rodovia ultrapassa as faculdades humanas; e de fato é assim, uma vez que esta circulação não coloca face a face nem homens nem leis naturais, mas sim sistemas de forças naturais bumanizadas pela intenção dos motoristas, e homens transformados em forças naturais pela energia física da qual eles se tornam os mediadores. Não se trata mais da operação de um agente sobre um objeto inerte, nem da reação de um objeto, promovido ao papel de agente, sobre um sujeito que se te- 
ria despossuído em favor do objeto sem nada pedir-lhe em retorno, ou seja, situações envolvendo, de um lado ou do outro, uma certa dose de passividade: os seres em presença se defrontam ao mesmo tempo enquanto sujeitos e objetos; e, no código usado por eles, uma simples variação na distância que os separa tem a força de um exorcismo mudo (LEVI-STRAUSS, 1962, p. 294, apud LATOUR, 2013, p. 54-55, itálicos nossos).

É na razoabilidade da "perspectiva antropológica selvagem", na qual se situa este humano "observador exótico" pré-antropocêntrico de Levi-Strauss, que Latour "inventa" ou "constrói” a sua ontologia de "seres híbridos" de "natureza" e "cultura" que habitam um "terceiro mundo metafísico" que não se situa, porém, para além da physis, mas que já "nasce" - como todo "embrião humano", como todo "embrião de leão" - indissociavelmente enxertado como physis humanizada em uma physis humanizada:

Talvez o quadro moderno houvesse conseguido se manter por algum tempo caso seu próprio desenvolvimento não houvesse estabelecido um curto-circuito entre a natureza, de um lado, e as massas humanas, de outro. Enquanto a natureza permaneceu longínqua e dominada, ainda se parecia vagamente com o polo constitutucional da tradição. Parecia reservada, transcendental, inesgotável, longínqua. Mas como classificar o buraco de ozônio, o aquecimento global do planeta? Onde colocar estes híbridos? Eles são humanos? Sim, humanos pois são nossa obra. São naturais? Sim, naturais porque não foram feitos por nós. São locais ou globais? Os dois. As massas humanas que as virtudes e os vícios da medicina e da economia multiplicaram também não são fáceis de mapear. Em que mundo abrigar estas multidões? Estamos no campo da biologia, da sociologia, da história natural, da sociobiologia? É nossa obra e, no entanto, as leis da demografia e da economia os ultrapassam infinitamente. A bomba demográfica é global ou local? Os dois. Portanto, tanto do lado da natureza quanto do lado do social, não podemos mais reconhecer as duas garantias constitucionais dos modernos: as leis universais das coisas, os direitos imprescritíveis dos sujeitos. O destino das multidões famintas, assim como o de nosso pobre planeta, encontram-se ligados no mesmo nó górdio que mais nenhum Alexandre virá cortar. Digamos, então, que os modernos quebraram. Sua Constituição podia absorver alguns contraexemplos, algumas exceções, até mesmo alimentava-se disto: mas tornase impotente quando as exceções proliferam, quando o terceiro estado das coisas e o terceiro mundo se misturam para invadir em massa todas as suas assembleias. Como Michel Serres, chamo estes híbridos de quase-objetos, porque não ocupam nem a posição de objetos que a Constituição prevê para eles, nem a de sujeitos, e porque é impossível encurralar todos eles na posição mediana que os tornaria uma simples mistura de coisa natural e símbolo social [o que mostra] o quanto o pensamento selvagem nos é próximo (LATOUR, 2013, p. 54, itálicos nossos). 
Colocando-se sob uma perspectiva antropológica pós-estrutural, o antropólogo brasileiro Eduardo Viveiros de Castro, em seu livro recentemente publicado sob o título Metafísicas canibais: elementos para uma antropologia pós-estrutural, desenvolve, esclarecendo-o, um ponto de vista semelhante ao de Latour:

O perspectivismo ameríndio conhece no mito um lugar geométrico onde a diferença entre os pontos de vista é ao mesmo tempo anulada e exacerbada. Nesse discurso absoluto, cada espécie de ser aparece aos outros seres como aparece para si mesma - como bumana -, e entretanto age como se já manifestando sua natureza distintiva e definitiva de animal, planta ou espírito. Ponto de fuga universal do perspectivismo, o mito fala de um estado do ser onde os corpos e os nomes, as almas e as ações, o eu e o outro se interpenetram, mergulhados em um mesmo meio pré-subjetivo e pré-objetivo. A finalidade da mitologia é precisamente a de contar o "fim" desse "meio": dito de outro modo, de descrever a "passagem da Natureza à Cultura", tema ao qual Lévi-Strauss atribui um papel central na mitologia ameríndia. [...] A passagem não é um processo de diferenciacão do bumano a partir do animal, como na vulgata evolucionista ocidental. A condição original comum aos bumanos e animais não é a animalidade, mas a bumanidade. A grande divisão mítica mostra menos a cultura se distinguindo da natureza do que a natureza se afastando da cultura: os mitos contam como os animais perderam atributos herdados ou mantidos pelos humanos. Os não bumanos são ex-bumanos, e não os bumanos os ex-não bumanos. Assim, se nossa antropologia popular vê a humanidade como erguida sobre alicerces animais normalmente ocultos pela cultura - tendo outrora sido "completamente" animais, permanecemos, "no fundo", animais -, o pensamento indígena conclui ao contrário que, tendo outrora sido humanos, os animais e outros existentes cósmicos continuam a sê-lo, mesmo que de uma maneira não evidente para nós (CASTRO, 2015, p. 59-60, itálicos nossos).

Então, com base nesse esclarecimento de Viveiros de Castro, poderíamos dizer que, sob a perspectiva antropológico-construcionista "selvagem" latouriana, a "construção cultural" do "mundo natural" não é propriamente feita através da inserção completamente distintiva e distinguível de um "terceiro mundo" de seres híbridos de natureza e cultura entre o mundo passivo e não humano da natureza e o mundo humano ativo da cultura. Esse "construcionismo" latouriano se manifesta, de um modo mais operacional, na sua "teoria ator(actante)-rede", na qual os "entes" produzidos pelos cientistas - porque indiretamente inferíveis de suas inves tigações laboratoriais -, bem como os artefatos tecnológicos, ao serem dotados de "vida própria", se tornam "bio-artefatos" híbridos de natureza e cultura. E daí, devido ao estatuto ontológico hibridamente difuso desses "bio-artefatos híbridos", o discurso requerido para se identificar, descrever e caracterizar os papéis e os efeitos que eles exercem sobre a natureza, desde o início e sempre constituída de "humanos", situa-se entre o discurso natural-empírico-factual das ciências da natureza modernamente visto como "não humano" e o discurso sócio-político-jurídico-constitucional das ciências sociais, modernamente visto como aquele que diria unicamente res- 
peito ao mundo dos "humanos". Tais "híbridos" são vistos por Latour como "construções" simultaneamente culturais e naturais, uma vez que se mostram ativos e têm o poder de interferir tanto no mundo natural quanto no humano, de modo que a natureza está sempre sendo humanamente reconstruída, redescoberta.

Penso que o "construcionismo" de Latour não poderia ser visto como um novo tipo de idealismo filosófico, dado que o "terceiro mundo" que ele "constrói" não é um mundo que estaria fora da natureza ou da cultura e nem rivaliza com elas. Melhor seria vê-lo como uma "construção cultural" simultaneamente humana e não humana que "produz" um mundo humano de actantes ${ }^{4}$ híbridos que podem agir e interagir com humanos e como humanos. Tais "actantes" podem associar-se entre si - não simultaneamente e nem da mesma forma, em função de propósitos contextuais humanos diversos e de meios técnicos para se atingi-los - mediante a constituição de uma diversidade de elos ou nós de trabalho entre actantes diversos, cujo fluxo associativo invisível, que em nada se assemelha fisicamente a uma rede, pode ser metodicamente descrito pela teoria-do-ator-rede (LATOUR, 2008, p. 207).

Entretanto, esse modo latouriano, pós-estrutural e pós-humanista, de desconstruir a dicotomia "natureza versus cultura", mediante o recurso de hibridização ou extensão do atributo de "humanidade" à natureza e aos artefatos culturais produzidos por humanos, parece ver a prática da análise político-cultural como um movimento unilateral que parte do "mundo do conhecimento" para os das diferentes organizações sociais e restrita à consideração de controvérsias de natureza sociotecnológicas e de seus efeitos globais. Ainda que pertinente, penso que a incorporação de híbridos ao "mundo do conhecimento" consegue, no máximo, antropologizar a epistemologia, sem sair da epistemologia, sem que se chegue a desconstruí-la enquanto uma teoria autônoma do conhecimento. E isso parece ocorrer porque os híbridos, ainda que passem a ser vistos como "actantes" tão "agentes" quanto os humanos, continuam sendo vistos como "sujeitos do conhecimento", eles próprios, independentes da linguagem vista como jogos de linguagem; mas também, porque sendo a "cultura" onto e epistemologicamente por ele vista como um mundo habitado por "seres actantes" "produzido" simultaneamente por humanos e não humanos, o significado atribuído à palavra cultura é o de "mundo produzido" e não o de mundo compartilhado no qual humanos e não humanos hibridizados simultaneamente se produzem.

Na sequência, vamos considerar uma outra proposta de desconstrução da dicotomia "natureza versus cultura". Simultaneamente orientado pelos pensamentos de Ludwig Wittgenstein e John Dewey, a desconstrução operada por Rupert $\operatorname{Read}^{5} \mathrm{da}$ dicotomia que se estabelece entre "natureza" e "cultura" é feita com o

\footnotetext{
${ }^{4} \mathrm{Na}$ teoria ator-rede, o termo "ator" é substituído pela palavra "actante", quer para se destacar o fato de actantes não serem, necessariamente, humanos - mas também, híbridos, tais como: computadores, sofwares, animais, objetos ou instituições quaisquer -, quer ainda para se pôr em evidência o papel igualmente ativo de actantes humanos ou híbridos, na constituição de redes.

${ }^{5}$ Rupert Read é professor de filosofia da University of East Anglia, em Norwich, no Reino Unido, onde desenvolve pesquisas em filosofia da linguagem, filosofia da ciência e filosofia ambien tal. É também político filiado ao Green Party da Inglaterra. Tal como Richard Rorty (1931-2007), as suas investigações filosóficas acadêmicas são orientadas pela perspectiva wittgensteiniana, bem como também inspiradas pelos trabalhos de John Dewey. Entretanto, Read se situa do lado
} 
propósito de se prevenir, educar e instrumentalizar humanos na luta organizada contra "eco-efeitos" políticos, econômicos e sociais conservadores e elitistas gerados pela perpetuação da dicotomia "natureza versus cultura", quer quando ela se manifesta no discurso de cientistas, de pensadores acadêmicos, de ambientalistas, quer quando ecoa no discurso legal das políticas ambientais contemporâneas.

Read focaliza, particularmente, os efeitos de dois "maus" usos acadêmicos da linguagem no modo de se considerar (tentando-se desconstruí-la, mas sem desconstruí-la, de fato) tal dicotomia: o primeiro que pensa poder desconstruí-la, assimilando um dos polos dessa dicotomia ao outro. Em outras palavras, ele afirma que um tipo de discurso (o "construcionista"), proveniente sobretudo do âmbito dos estudos culturais, do modo como têm sido realizados por integrantes da comunidade de críticos literários, ao transformar tudo em "texto", acaba defendendo o ponto de vista de que a natureza seria uma construção cultural humana. Read critica, nos seguintes termos, o que ele denomina "tese culturalista/construcionista", nos dois diferentes usos que os seus defensores fazem da palavra "construção", quer quando usada com o significado de "re-construção" biotecnológica da natureza, quer quando usada com um "novo" significado filosófico-idealista metafísico, segundo o qual é feita uma ampliação artificial e arbitrária ilimitada do termo "cultura" de modo a abarcar "literalmente" toda a natureza:

[...] é preciso considerar uma ambiguidade sistemática no termo "construir" [...]. Ou seja, o termo contempla que, hoje em dia, a Civilização (re)constrói de maneira ilimitada a natureza fisicamente/materialmente, por meio de nosso ganancioso poder biotecnológico? Ou será que se trata de um sentido mais fundamental de construção "metafísica" por meio de categorias representacionais ou categorias do pensamento? No primeiro sentido, é completamente claro que, pelo menos, alguns elementos da natureza continuarão impérvios ou anteriores à construção humana. Isto é, os seres humanos não podem, literalmente, criar ou construir todos os fenômenos (ou até mesmo a maioria deles) que temos a intenção de chamar de "naturais", mesmo que seja possível alterar ou destruir - reconstruir, talvez - muitos deles. Quanto ao último sentido puramente metafísico de "construir": se tudo é construído culturalmente, se tudo pode ser colocado dentro da categoria "cultural", então nada é explicado pelo simples evocar da "construção social/cultural". Dizer que a natureza é totalmente construída de forma cultural, nesse sentido, na verdade, é não dizer nada. O mesmo acontece se pensarmos [...] na construção cultural em questão como desempenhada por meio de uma cultura científica. Afinal, tal construção só pode ser reconstrução de algumas coisas; caso se suponha que ela se estende a tudo, então, estamos apenas expressando a nossa determinação de não permitir que nada seja descrito em termos que não sejam científicos. Continuamos sem dizer nada nesses (ou em quaisquer outros) termos. Em suma, qualquer plausibilidade presente em uma tese

oposto àquele no qual se situava Rorty na segmentação feita por este dos seguidores de Wittgens tein, na atualidade, em duas categorias: os wittgensteinianos pragmáticos, com os quais se identificava Rorty e os wittgensteinianos terapêuticos, dentre os quais Read se inclui. 
culturalista/construcionista evapora-se, uma vez que seja revelada sua ambiguidade intrínseca, quando percebemos que tal tese é falsa (se tomada no sentido material) ou vazia (se tomada no sentido metafísico) (READ, 2009, p. 18, itálicos do autor).

Um movimento no sentido contrário é também feito por Read, a fim de explicitar uma ambiguidade análoga manifesta em usos do termo "natureza" por biocentistas e ambientalistas. Em um desses usos, a natureza é vista como uma totalidade universal à qual tudo está inevitavelmente submetido e subordinado. Em outro, ela é vista como não podendo ser dominada pelos humanos, porém, potencialmente separável da cultura humana. Sem, é claro, tentar inibir os usos dos termos "natureza" e "cultura", a desconstrução terminológica da dicotomia "natureza versus cultura" feita por Read sugere deixarmos de lado os debates teóricos ou teorizantes referentes a essa dicotomia e passarmos a nos envolver tão somente em debates e embates políticos situacionais e efetivos, abandonando os usos dessas palavras e substituindo-as pela palavra "ecossistemas":

A natureza não pode ser "naturalizada" (isto é, tomada como referência de alguma entidade realmente existente, seja pela redução ou por algum outro meio teórico), nem proveitosamente evocada no discurso ético. Se encararmos a nós mesmos desde já como parte da maioria dos ambientes que descrevemos, o termo ambiente pode nos ajudar a ter sucesso onde os termos dualísticos falharam. Se entendermos ambiente não como um sinônimo próximo de natureza, falar sobre o ambiente do sujeito não precisa ser uma tentativa de diferenciar entre primeira natureza, segunda natureza e não natureza. [...] Contudo, um problema simples, porém crucial, permanece ainda é muito fácil perceber o ambiente do sujeito como algo externo a ele. Há um termo que contorna essa dificuldade, enquanto preserva todas as vantagens do termo ambiente detalhadas acima e continua fiel aos insights de Wittgenstein e de pensadores afins: ecossistema. [...] Focar no(s) ecossistema(s) (inclusive nós) como um conjunto, uma totalidade para a qual possamos (e inevitavelmente iremos) fazer uma diferença, pode ser fortalecedor e promissor. Especificamente, uma vez que sejamos não antropocêntricos ao ponto de dizer que "o valor dos processos e objetos naturais não é redutível às preferências ou aos interesses humanos", nem ao "valor da experiência humana ou a formas de consciência incitadas por elas", então, a Ética ambiental será, inegavelmente, centrada no ser humano [somente] de modo a obscurecer a distinção entre valores puramente 'humanos' e puramente 'ambientais'. Qualquer esforço mais "radical" de teorizar e praticar um sistema de valores "independente" dos humanos incorre na noção incoerente de animais humanos que julgam e agem por meio de critérios totalmente independentes de si próprios, como se, por encanto, tivessem sido escritos em algum lugar ou ditados por um dirigente incorpóreo (READ, 2009, p. 23-24, itálicos do autor). 
É preciso destacar o fato de que essa "eco-ética" anti-teórica e "póshumanista" - porque, embora estabelecida e praticada por humanos, não se centra exclusivamente nos humanos e nos interesses humanos, mas sim, nos ecossistemas - defendida por Rupert não pode ser vista como politicamente neutra:

Deveríamos, portanto, ir além das defesas românticas ou "profundas" da natureza, com seus correspondentes perigos estruturais de se valorizar "a norma" ao mesmo tempo em que se afirma "o ambiente natural" (compare-se: "sexo" heterossexual e reprodução é natural, é normal) e, sem dúvidas, irmos simultaneamente além da imagem reversa (para a defesa da natureza), a exploração e dominação da natureza. Não pode haver nenhum pré-conceito nem contra nem a favor das intervenções técnico-científicas no(s) ecossistema(s): cada caso deve ser julgado de acordo com seus méritos, pragmaticamente. [...] Os disfarces [de que tais intervenções seriam livres de valores] de fato devem ser questionados, particularmente no que se refere à cumplicidade oculta de ideologia de "livre mercado" com os agravamentos e ameaças feitas a muitos de nossos ecossistemas (READ, 2009, p. 25).

O que se percebe, no modo como Read (2009) retoma e caracteriza esse debate no qual se envolvem tanto defensores quanto críticos da tese construcionista/culturalista, é que o termo "cultura" acaba sendo mobilizado com o mesmo significado de "aquilo que é produzido por humanos". Em outras palavras, o debate da dicotomia que se estabelece entre "natureza" e "cultura" acaba sendo sub-repticiamente - e indevidamente - "traduzido" ou "convertido" num outro relativo à dicotomia que se estabelece entre "humanos e não humanos" ou, mais propriamente, à dicotomia que se estabelece entre o que poderia "ser produzido por humanos" e o que, supostamente, poderia ser ou não produzido por "não humanos".

Penso, então, que para além de uma polêmica em torno de uma "ambiguidade" no uso da palavra "construção" - como o constata Read -, a íntima conexão que se manifesta entre essas duas dicotomias correlacionadas se deve, também, não propriamente a uma "ambiguidade", mas a modos legitimamente diferenciados - e sempre com efeitos político-ideológicos conflitantes - de se mobilizar, sobretudo, a palavra "cultura" em nossos discursos. Embora este meu ponto de vista me leve a concordar com a maior parte da argumentação de Read em relação ao seu modo wittgensteiniano de desconstruir a dicotomia "natureza" versus "cultura", não vemos, entretanto - como o vê Read na defesa que faz do uso do termo "ecossistema" -, a necessidade de se ir além dos dois "quase-conceitos" - jogos de linguagem e formas de vida - já mobilizados por Wittgenstein em seus escritos, para se proceder a essa desconstrução.

Isso porque, se nos parecer legítimo usar a palavra "vida" para significar o surgimento de novos "seres naturais" resultantes de determinados tipos 
de interação que se estabelece entre diferentes "seres naturais", então, todos os seres que habitam o planeta - inclusive os que denominamos "humanos" - podem ser vistos como seres indissociavelmente "híbridos", isto é, simultaneamente humanos e não-humanos. E se nos parecer igualmente legítimo usar a palavra "cultura" não para se distinguir, mas exclusivamente para se classificar essa diversidade irredutível e sempre em expansão de "híbridos" com base no critério bumano da diversidade de atividades que eles podem constituir e compartilhar em função de diferentes propósitos humanos a serem atingidos -, então, as diversas e ilimitadas formas compartilhadas de atividade geradas por essa classificação podem ser denominadas formas culturais de vida.

Nesse sentido, os próprios maus usos que nós, "humanos" - seres híbridos constituídos por "natureza" e "cultura" -, para nos distinguirmos e nos destacarmos ilegitimamente da "natureza", costumamos fazer do adjetivo "humano" em nossos jogos "culturais" de linguagem, produzem, concomitantemente, maus usos "culturais" da palavra "natureza". Por sua vez, esses maus usos da palavra "natureza", por ocultarem o seu caráter também híbrido, acabam subtraindo do seu âmbito e do seu poder os próprios "humanos", bem como os demais seres híbridos, materiais ou imateriais, tangíveis ou intangíveis, produzidos por "humanos", tais como: cestos, casas, túneis, estradas, vinho, plantas cultiváveis, animais domesticáveis, máquinas mecânicas, máquinas eletrônicas, técnicas de navegação, deuses, danças, rituais, obras de arte, energia, ondas eletromagnéticas, átomos, moléculas, consciência, eu, mente, inconsciente, sistemas numéricos, leis naturais, comunidades de prática, linguagens orais, linguagens escritas, linguagens simbólicas, quaisquer outros jogos de linguagem, teorias, cosmogonias, práticas de navegação, quaisquer outras práticas etc.

Há que se reconhecer, portanto, que "humanos", "não humanos", "natureza", "cultura" e as dicotomias entre "humano" e "não humano", por um lado, e entre "natureza" e "cultura", por outro, são tão somente alguns dos "seres" genéricos e dicotômicos produzidos por nossos jogos lógico-culturais de linguagem. Urge, portanto, desconstruir essas generalizações e dicotomias, bem como o debate que em nome delas vem se travando há séculos, dado que os efeitos ideológicos por eles gerados vêm, cada vez mais, empoderando ilegitimamente certos híbridos em relação a outros, bem como produzindo antagonismos, desentendimentos, conflitos, lutas de poder, dominação e exploração entre híbridos, ameaçando o equilíbrio biopolítico da biodiversidade de atividades culturais híbridas - isto é, de formas de vida - de nosso planeta e, por extensão, o justo direito à co-vivência e convivência dignas e negociadas de todas as formas de vida, com base na urgente constituição de uma ética biopolítica global reguladora das atividades dessas diferentes formas de vida. Apenas um tal tipo de ética poderá ressignificar ou mesmo evitar os usos dessas e de outras palavras "carregadas" de conflito, ainda que uma tal ressignificação não possa assegurar, é claro, a dissolução permanente de conflitos e lutas de poder que se estabelecem no interior de e entre as diferentes formas de vida. Quero com isso dizer, parafrase- 
ando, de certo modo, o Foucault do A ordem do discurso (FOUCAULT, 2004, p. 10), que a luta global de poder que se estabelece no interior de e entre diferentes formas de vida - por serem os híbridos que as integram coparticipantes de jogos de linguagem entretecidos nessas formas de vida - é também uma luta que se trava em, com, entre e através de jogos de linguagem e pela conquista do poder da linguagem ${ }^{6}$.

Penso, então, que, numa perspectiva wittgensteiniana, o uso da palavra "culturas" poderia conectar-se intimamente, porém, sem ser identificado - ao uso que Wittgenstein faz, no plural, da expressão "formas de vida". O cuidado que temos tido, em nossos trabalhos, em não identificar "formas de vida" com "culturas" talvez esteja pautado em um cuidado semelhante demonstrado pelo próprio Wittgenstein em não fazer essa identificação. Nas poucas vezes em que ele mobiliza tais expressões linguísticas em seus escritos, ele demonstra o cuidado em não trazê-las juntas ou identificá-las, ainda que possamos acusar semelhanças de familia entre tais usos.

Nesse sentido, se a palavra "vida" em "formas de vida" não for exclusiva e restritamente significada como "vida humana", então, poderia ter sido proposital, por parte de Wittgenstein, manter a ambiguidade da expressão "formas de vida", de modo a se permitir também usá-la no sentido mais restrito de "formas de vida humana". Por outro lado, nas poucas vezes em que Wittgenstein faz uso da palavra "cultura", tais usos parecem estar restritamente conectados a "formas humanas de vida". Entretanto, tal uso restrito da palavra "cultura" não nos permite inferir, apressadamente, que formas "culturais" de vida humana pudessem se constituir independentemente de formas "naturais" de vida, dado que, uma "cultura", isto é, uma forma "cultural" de vida humana, não pode se constituir - e muito menos subsistir - fora do tempo e do "espaço" e independentemente da interação com outras formas "naturais" de vida que coabitam conosco, humanos, o mesmo "espaço físico vital". Assim, a expressão "formas culturais de vida", numa perspectiva wittgensteiniana, em vez de necessariamente acusar uma identificação pleonástica entre os usos das expressões "cultura" e "cultura humana", poderia também estar sugerindo a inútil e desnecessária - porque indecidivel - tentativa de se estabelecer, com base em quaisquer critérios supostamente considerados "legítimos" ou "racionais" (sob a perspectiva dos humanos), uma rígida distinção entre o que pertenceria, por um lado, ao "domínio cultural" dos humanos e, por outro lado, ao "domínio supostamente não cultural" dos "não humanos". Não podemos nos esquecer de que vem de Wittgenstein o sutil aforismo "em favor" dos não humanos: "Se o leão pudesse

\footnotetext{
${ }^{6}$ Foucault disse algo semelhante a isso do seguinte modo: "Por mais que o discurso seja aparentemente bem pouca coisa, as interdições que o atingem revelam, logo rapidamente, sua ligação com o desejo e com o poder. Nisto não há nada de espantoso, visto que o discurso - como a psicanálise nos mostrou - não é simplesmente aquilo que manifesta (ou oculta) o desejo; é também, aquilo que é o desejo do desejo; e visto que - isto a história não cessa de nos ensinar - o discurso não é simplesmente aquilo que traduz as lutas ou os sistemas de dominação, mas aquilo por que, pelo que se luta, o poder do qual nos queremos apoderar" (Foucault, 2004, p. 10).
} 
falar, nós [humanos] não entenderíamos" (WITTGENSTEIN, 1979, IF - Parte II, seção XI, p. 216).

Assim, soa-me plenamente legítimo e não ambíguo denominar "formas culturais de vida" ou, simplesmente, "formas de vida", tanto os modos como as abelhas ou as formigas organizam as suas vidas e constroem literalmente artefatos culturais híbridos, tais como colmeias e formigueiros (no sentido em que tais "híbridos" são produtos da interação de uma ou mais formas de vida), como também os modos como humanos, necessariamente interagindo com não humanos, intencionalmente organizam as suas vidas em campos de atividade, tais como: o da construção civil; os da navegação marítima, aérea ou ciberespacial; o campo petrolífero, o campo familiar, o campo educativo escolar, o campo de pesquisa acadêmica, o campo de gestão política de um Estado-Nação etc.

Adjetivar tais formas de vida, isto é, tais formas de organizar a vida, como mais ou menos "intencionais", "racionais", "culturais", "naturais", "inteligentes", "complexas" etc. é completamente dispensável ou inútil, porque isso significa fazer um mau uso (humano) da linguagem verbal (também ela um "híbrido") de nossas formas de vida para se atribuir indecidiveis a outras formas de vida, por mais que nós, humanos, tenhamos o desejo de humanizar as formas de vida com as quais não podemos compartilhar ou negociar uma linguagem comum.

Penso, então, que "vida", e, por extensão, a expressão wittgensteiniana "formas de vida", vistas como quase-conceitos expressando um conjunto ilimitado e dinâmico de práticas interativas que se estabelecem entre diferentes formas de vida, são as únicas expressões que podem desconstruir consequentemente a dicotomia "natureza versus cultura" e substituir termos ambíguos geradores de efeitos ideológicos indesejáveis. Portanto, é sempre com base em uma bioética politica bumana, normativa e situada - e, portanto, também relativa e retificável constituída através de um diálogo democrático-praxiológico mudo, porém, sensível, politicamente atento e negociado - que podemos e devemos praticar a biodiversidade, o que significa, por extensão, inibir ou impedir a realização de práticas que ameacem ou atentem contra a manutenção da vida digna e sustentável de todas as formas de vida pautadas nessa bioética política.

É esta biopolítica bíbrida, vista como uma prática normativa para além de sua mera constituição jurídica, que nunca poderá estar completa e definitivamente negociada e escrita, que deve, porém, orientar a realização de práticas performativas - vistas, com base em Wittgenstein, como jogos de linguagem ou encenações simbólico-corporais regradas de signos socialmente compartilhados na forma de vida em que tais jogos são encenados e com as quais se entretecem - e performáticas. E são tais práticas que produzem novas práticas mobilizadoras de novos saberes, conhecimentos, artefatos tecnológicos etc. os quais, por sua vez e por esta razão, não podem ser, em nome de outros propósitos, desconectados dessas práticas sob pena de ou serem descaracterizados ou de passarem a ser praticados de outras maneiras. 
Assim, não há saber que não seja um saber fazer num jogo de linguagem (ou prática) entretecido numa forma de vida, de modo que "saber"; "fazer, "praticar" ou "jogar com uma linguagem" em uma "forma de vida" formam um "trio semântico" indissociável que só pode adquirir uma significação objetiva compartilhada quando este "saber" for, necessariamente, um "saber-fazer" num "jogo de linguagem" entretecido numa "forma de vida". Desligado desse "trio semântico", um saber pode adquirir outras e novas significações desde que se conecte significativamente a outros trios semânticos. Na sequência, vamos fornecer alguns exemplos.

Saber orientar-se no espaço não constitui nem um "saber em si" e nem uma "competência em si" cuja aprendizagem pudesse ser objetivamente avaliada ou verificada. Entretanto, "saber orientar-se no espaço" pode constituir diferentes práticas, isto é, diferentes modos de "saber-fazer", com diferentes significados social e objetivamente compartilhados e compartilháveis, quando esse "saber em si" "indeterminado" ou "não referenciado" é "alocado" em diferentes "trios semânticos" constitutivos de diferentes práticas, tais como:

- saber orientar espacialmente o deslocamento de um navio no mar, utilizando-se de técnicas e artefatos tecnológicos de navegação significa realizar uma prática de deslocamento espacial, na forma de vida da navegação maritima, sabendo usar as linguagens especificas que acionam adequadamente outras formas hibridas de vida - "artefatos tecnológicos", tais como: o próprio navio a ser conduzido, GPS, computadores, mapas, cartas náuticas, instrumentos meteorológicos, instrumentos de medição diversos etc.; "técnicas de navegação" tais como: técnicas de orientação marítima, de condução do navio no mar, de desvio e correção de rotas etc. - que compartilham com os humanos que participam da forma de vida da navegação marítima a realização bem ou mal sucedida da prática de se conduzir um navio de um porto a outro.

- saber orientar espacialmente o deslocamento de um avião de um aeroporto a outro, utilizando-se de técnicas e artefatos tecnológicos da navegação aérea significa realizar uma prática de deslocamento espacial, na forma de vida da navegação aérea, sabendo usar as linguagens específicas que acionam adequadamente outras formas bibridas de vida - "artefatos tecnológicos" tais como: o próprio avião; GPS; computadores; mapas; instrumentos meteorológicos; instrumentos de medição diversos, tais como altímetros, termômetros, barômetros etc.; instrumentos de comunicação e acesso de informações a distância; mapas de rotas de navegação aérea etc.; "técnicas de navegação aérea" diversas, tais como: técnicas de desvio e de correção de rotas, técnicas de decolagem e aterrisagem, técnicas de comunicação a distância etc. - que compartilham com os humanos que participam da forma de vida da navegação aérea a realização 
bem ou mal sucedida da prática de se conduzir um avião de um aeroporto a outro.

- saber orientar-se espacialmente de um local a outro de uma cidade grande e movimentada, conduzindo um automóvel, sem que se conheça o trajeto a ser seguido, significa realizar uma prática de deslocamento espacial, na forma de vida do tráfego rodoviário urbano, sabendo usar as linguagens especificas que acionam adequadamente outras formas bibridas de vida - "artefatos tecnológicos", tais como: o próprio automóvel que se dirige; as leis do trânsito rodoviário urbano, GPS, mapas rodoviários urbanos etc.; "técnicas de condução de automóveis", tais como: técnicas de direção, técnicas de marcha à ré, técnicas de baliza e estacionamento do veículo etc. - que compartilham com os humanos que participam da forma de vida do tráfego rodoviário urbano a realização bem ou mal sucedida da prática de se conduzir um automóvel de um local a outro de uma cidade.

Mas, se são sempre biopolíticas situadas específicas - explícitas ou não - que orientam normativamente a produção e a reprodução de formas sustentáveis de vida em todas as formas humanas de vida, são também elas que estão na base de todas as práticas educativas diretas - intencionais ou não - que devem necessariamente ser realizadas em cada uma dessas formas humanas de vida, para que elas possam continuar contemplando os propósitos humanos com base nos quais elas se constituíram e continuam a reproduzir a vida de forma bem sucedida, no seu interior. Por exemplo: a bioética que orienta normativamente a produção e a reprodução de formas de vida granjeiras, em nosso país, é constituída não apenas por leis específicas expedidas pelo Ministério da Agricultura, Pecuária e Abastecimento, como também, por leis trabalhistas expedidas pelo Ministério do Trabalho, por regras que regulam a comercialização, o transporte e o armazenamento dos produtos da granja, por códigos de boa conduta que regulam as relações humanas no interior dessas formas de vida etc. Atentemo-nos para alguns dos parágrafos da Portaria número 1, de 21 de fevereiro de 1990, expedida pela Secretaria de Inspeção de Produto Animal, que define normas de inspeção de ovos e derivados:

- "Ovo" - pela designação "ovo" entende-se o ovo de galinha em casca, sendo os demais acompanhados da indicação da espécie de que procedem.

- "Ovo Fresco" - entende-se o ovo em casca que não foi conservado por qualquer processo e se enquadre na classificação estabelecida. Este ovo perderá sua denominação de fresco se for submetido intencionalmente a temperaturas inferiores a $8^{\circ} \mathrm{C}$, visto que a temperatura recomendada para armazenamento do ovo fresco está entre $8^{\circ} \mathrm{C}$ e $15^{\circ} \mathrm{C}$ com uma umidade relativa do ar entre $70 \%-90 \%$. 
- "Ovo Frigorificado" - entende-se o ovo em casca conservado pelo frio industrial nas especificações do Art. 725 da RIISPOA.

- "Conserva de Ovos" - entende-se o produto resultante do tratamento do ovo sem casca ou partes do ovo que tenham sido congelados, salgados, pasteurizados, desidratados ou qualquer outro processo devidamente aprovado pela SIPA.

- "Ovo Integral" - entende-se o ovo em natureza desprovido de casca e que conserva as proporções naturais da gema e clara. Quando misturados, resultam em uma substância homogênea.

- "Gema" - entende-se o produto obtido do ovo desprovido da casca e separado da clara ou albumina.

- "Clara" - entende-se o produto obtido do ovo desprovido da casca e separado da gema.

Todas as práticas realizadas em formas de vida granjeiras, em nosso país, devem ser realizadas em conformidade a uma biopolitica granjeira - isto é, em conformidade às aqui referidas e a outras regras que orientam normativamente todas as práticas envolvendo humanos e não humanos entre si, de modo que, nas formas de vida de granjas, nem um "ovo" e nem uma "galinha" que o bota são objetos comestíveis como o são, por exemplo, os ovos de galinha e as próprias galinhas que compramos em supermercados para consumirmos; ovos e galinhas não são objetos que se comem, mas que se selecionam, que se higienizam, que se rotulam, que se contam e se embalam, que se comercializam e se transportam, que se vendem e se trocam. Além disso, nas formas de vida das granjas, um ovo "de" uma galinha não é mais dessa galinha, não é mais propriedade dela e, talvez, essa galinha nunca tivesse visto o seu próprio ovo como uma propriedade sua, nem o tivesse visto como um direito adquirido e nunca tivesse vivenciado nada semelhante a um sentimento de posse. Nas granjas, tanto galinhas quanto os seus ovos são propriedades do dono da granja e são vistos por ele dessa maneira, como algo que ele possui, como um direito adquirido, como bens dotados de valor de troca. Nesse mundo, um "ovo" não é o que nos acostumamos a chamar de "ovo" em outras formas de vida; não é, por exemplo, um "ovo" de Páscoa; além disso, nas granjas, um "ovo" nem sempre é igual a outro "ovo". No mundo das granjas, "ovos", "galinhas" e "humanos" são objetos normativos que devem manipular e/ou ser manipulados normativamente, isto é, com base em normas que devem ser vistas como um dado (MIGUEL, 2014).

Quaisquer semelhanças de familia que possam ser acusadas entre o texto legal "granjeiro" acima referido - ou outro texto legal qualquer produzido na forma de vida da jurisprudência e do poder judiciário de um Estado-Nação, isto é, no modo como a vida se organiza nessa forma de vida - e o texto dos Elementos de Euclides (com as suas definições, postulados, axiomas e teoremas), ou um texto matemático produzido na forma de vida científico-acadêmica do mundo contemporâneo, não são meras coincidências. Tratam-se, todos, de textos normativos ou 
bio-ético-políticos - "híbridos" carregados de poder -, produzidos em determinadas formas de vida, com o propósito de orientar normativamente as ações e interações vitais entre humanos e não humanos em outras formas de vida.

Textos normativos ou bio-ético-políticos não são textos empíricos, descritivos ou narrativos; não descrevem ou narram, com base em observações ou inserções empírico-etnográficas, o modo como a vida, de fato, se processa e transcorre em outras formas de vida; não narram ou descrevem como a vida é numa forma de vida, mas sim, como ela deve ser para se ajustar a um desejado modelo pré-estabelecido de funcionamento, para se ajustar a uma fôrma, a uma forma; ajustar-se não propriamente à vida, mas a uma forma de vida. "O aceito, o dado - poder-se-ia dizer - são formas de vida", diz Wittgenstein (IF- Parte II, p. 218 , itálicos do autor).

São, portanto, em diferentes formas humanas de vida, constituídas para se atingir propósitos sociais diversos, que humanos, interagindo entre si e com outras formas de vida, produzem "saberes" que são sempre, saberes-em-trio, isto é, amálgamas indissociáveis entre um saber-fazer com o corpo (isto é, uma prática) e com um jogo de linguagem entretecido na bio-ético-política constitutiva de numa forma de vida. Assim, um saber-fazer com o corpo é sempre uma prática que só pode adquirir significações objetivas compartilhadas quando esta prática estiver conectada em um trio semântico (prática; linguagem; forma de vida). Desligado ou abstraído desse trio, um saber-fazer, uma prática, ou se destrói como saber ou se reconecta a outro trio semântico, adquirindo novas significações. Isso acontece com todas as práticas e, portanto, também, com as práticas que costumamos denominar "matemáticas".

$\mathrm{Na}$ segunda metade do século X, circulou na cidade de Damasco um texto de Aritmética manuscrito por al-Uqlīdisī (SAIDAN, 1975) - digamos, um "híbrido" produzido na forma de vida do islamismo, intimamente acoplada à forma astrológico astronômica de vida das investigações dos fenômenos celestes - com o propósito de divulgar, entre os árabes medievais, a prática do ábaco, do modo como tal prática já vinha sendo, há anos, praticada entre os hindus, também e sobretudo, no interior da forma de vida hinduista, então acoplada à forma de vida das investigações dos fenômenos celestes.

Quando lemos o prefácio dessa Aritmética, escrito pelo próprio alUqlīdisī, salta aos olhos o valor desigual que era atribuído à prática do ábaco, bem como a maior ou menor resistência à sua aceitação, por diferentes bumanos envolvidos em diferentes formas de vida humana que conviviam na mesma cidade de Damasco. Com base na natureza da argumentação favorável à adoção da prática bindu do ábaco apresentada por al-Uqlīdisī, é possível inferir ter-se manifestado, no processo de sua recepção por parte de alguns humanos que viviam em Damasco, uma dupla resistência de natureza preconceituosa. Um primeiro preconceito teria se manifestado em relação aos astrólogos pobres que tentavam "ganhar a vida" nas ruas e nos mercados de Damasco fazendo prognósticos, horóscopos e mapas astrais das vidas dos transeuntes que os procuravam e os pagavam para a 
realização desse trabalho, para o que, tais astrólogos recorriam à prática hindu do ábaco. Dado que al- Uqlīdisī, no prefácio, argumenta no sentido de desconectar a prática "estritamente operatória" do ábaco da prática realizada pelos astrólogos pobres de prognosticar o futuro, mal vista por outros bumanos abastados integrantes de outras formas de vida - a dos comerciantes, a dos navegadores, a dos astrônomos-investigadores dos fenômenos celestes para fins religiosos, a dos escribas palacianos calculadores de impostos etc. -, então, o preconceito à forma de vida dos astrólogos - que, talvez, menos por serem astrólogos e mais por serem pobres - se transmitia também para a própria prática do ábaco ao modo hindu (SAIDAN, 1975; SOUZA, 2004).

Nesse processo de recepção, um segundo preconceito se manifestou em relação aos próprios bindus, ou melhor, à forma de vida binduista dos astrônomos bindus que praticavam a prática do ábaco, razão pela qual al-Uqlīdisī se esforça, no prefácio de sua aritmética, para tentar convencer os seus leitores de que seria possível apropriar-se tão somente da prática "estritamente operatória" do ábaco hindu desconectando-a de sua própria origem hindu. Os árabes já faziam os seus cálculos aritméticos através de um jogo de linguagem que os levava a utilizarem-se, exclusivamente, dos dedos das mãos, não necessitando, portanto, para realizarem seus cálculos, recorrer a qualquer tipo de artefato mediador concreto, tal como ocorria com a prática do ábaco do modo como praticada pelos hindus, que requeria o uso de uma placa de areia, na qual eram traçados e realizados, com os dedos, os algoritmos das operações aritméticas. O ábaco hindu era, portanto, diferente dos ábacos gregos e romanos, não apenas porque as contas de pedra ou outro material eram substituídas por areia e dedos, mas, sobretudo, porque os cálculos aritméticos eram diretamente realizados com os símbolos dos algarismos do sistema numérico posicional hindu, mediante as regras de um jogo de linguagem que já, entre eles, orientava o modo de se registrar quantidades com base nesse sistema.

Então, para apagar a memória da origem hindu da prática hindu do ábaco, al- Uqlīdisī sugeria a seus leitores que substituíssem o mal visto ábaco de areia hindu por pena, tinta e papel, não apenas porque o uso desses novos intermediários do cálculo aritmético evitava que o calculador sujasse os seus dedos com areia, bem como que se apagasse os símbolos impressos na areia, mas também - $e$ sobretudo -, porque pena, tinta e papel eram produtos que, na época, provinham da cidade de Bizâncio. E dado que os povos islâmicos mantinham uma boa relação com os bizantinos - uma vez, no século X, os muçulmanos ainda ocupavam parte do Império Bizantino -, o mesmo não acontecendo com os hindus, povo com tradição religiosa hinduísta, uma tal substituição dos elementos mediadores do cálculo escrito poderia não só impedir que os cálculos escritos com tinta no papel se apagassem, mas também, que se apagasse a memória da própria origem hindu da prática do ábaco.

Este, dentre outros inúmeros exemplos que poderiam ser aqui trazidos, nos sugere como um saber-fazer com o corpo e com um jogo de linguagem en- 
tretecido numa determinada forma de vida humana, ao adentrar outras formas de vida - e para nelas se ajustar e poder contemplar os novos propósitos sociais que lhe estão reservados - precisa, sempre, se desconectar do seu trio semântico "original" e conectar-se a outros trios semânticos dessas outras formas de vida adentradas. Assim, em seu trânsito complexo e descontínuo de desconexões e reconexões semânticas, uma prática (um saber-fazer), ao mesmo tempo em que é iterada ou repetida, é também performada, transformando, no seu transitar, não só os suportes mediadores concretos, as regras, os valores, os afetos, as crenças, os poderes e as memórias que possibilitam as diferentes mobilizações dessa prática, mas também, e portanto, o próprio saber-fazer por ela mobilizado.

De fato, como vimos, no trânsito da prática do ábaco de formas de vida constituídas em território geográfico hindu para outras constituídas em território da Síria medieval, tudo se modifica. Do cálculo hindu, participavam os híbridos areia, placa, inscrições na areia em conformidade aos sinais do sistema numérico hindu, aos quais se agregavam valores religiosos e sagrados da tradição religiosa hinduísta, dentre outros. Já do cálculo hindu transfigurado pelos árabes participavam tinta, pena, papel, inscrições no papel em conformidade aos sinais do sistema numérico arábico, aos quais se agregavam valores, tais como: mascaramento da origem hindu da prática; falsa atribuição da origem bizantina da prática; limpeza, rapidez, precisão e durabilidade dos registros na realização de cálculos aritméticos, dentre outros.

Algo análogo ocorreu no trânsito da prática do ábaco de formas de vida instituídas no mundo árabe para outras formas de vida (de comerciantes, de financistas, de guarda-livros ou contabilistas, de navegadores, dentre outros) da Europa cristã, no início da Idade Moderna. Não vamos contar aqui esta his tória; basta apenas registrar o fato de que o primeiro livro impresso de Aritmética na Europa moderna - a intitulada Aritmética de Treviso, porque escrita na cidade italiana de Treviso - é um livro anônimo, de modo que a prática do ábaco hindu que havia sido transmitida pelos árabes aos europeus não era mais nem hindu e nem árabe, mas simplesmente "de Treviso" (SWETZ, 1989). Mas, para além de todas as suas transfigurações materiais e valorativas, a prática do ábaco dos hindus - mesmo sob o anonimato das marcas anônimas da prensa de tipos móveis de Gutenberg - continuou, no discurso anônimo do anônimo de Treviso, a ser vista simplesmente como uma prática... anônima.

Este trânsito de uma prática social específica, do modo como nós o descrevemos com base em quase-conceitos wittgensteinianos e derridianos - iterabilidade, performatividade, jogos de linguagem, formas de vida, semelhanças de familia -, em nada se assemelha visualmente a uma rede de pesca inconsútil, tal como nos sugere a proposta de unidade do saber de Wilson, baseada em um tipo de consiliência disciplinar de natureza cientifico-explicativa. Não se assemelha visualmente também a uma worknet, isto é, a uma rede de trabalho, significação esta que Latour gostaria de ver associada à infeliz palavra network da sua Actor-Network- Theory, geradora de tantas significações visuais por ele mesmo consideradas impróprias. 
Mas o exemplo que demos do trânsito histórico da prática do ábaco por diferentes formas de vida nos sugere também que os nossos currículos escolares de matemática, justamente por serem organizados por "conteúdos", "conhecimentos" ou "saberes-em-si" desconectados das práticas que os mobilizaram em diferentes formas de vida humana, de certo modo, já "optaram" por eliminar da escola toda uma desejável investigação e problematização ético-biopolítica em torno dos valores, das resistências, das relações de força e poder que permeiam todas as práticas - sejam elas consideradas ou não "matemáticas" - em seus trânsitos históricos descontínuos por diferentes formas de vida. Em outras palavras, os nossos currículos escolares centrados em "conteúdos" sem práticas, sem corpo, sem humanos, sem não humanos, sem híbridos, sem propósitos, sem interesses, sem conflitos, sem valores e sem forma abstraíram das formas de vida exatamente as vidas, mantendo-lhes tão somente as formas, subtraindo da escola a possibilidade de, nela, se dialogar com as vidas, com as formas de vida.

Após todos esses "arbitrários expurgos vitais", as práticas sociais, ao adentrarem os muros escolares sem terem deixado quaisquer rastros ou "sinais de vida", adquirem a enganosa aparência fisionômica de "saberes-em-si": verdadeiros, universais, objetivos, bons e livre de valores. Mas, ao adentrarem os muros escolares, tais práticas não são apenas transfiguradas em conteúdos-em-si; elas também se agregam a outros conteúdos-em-si, desconectados de outras práticas e de outras formas de vida, bem como a outros valores, de modo a constituírem o que, desde o final do século 19, tem sido denominado uma "disciplina escolar".

De fato, no processo de constituição da Aritmética como uma disciplina escolar, na Inglaterra do século XVIII, é possível acusar o tipo de transfiguração abstracionista e reducionista por que passaram certas práticas sociais que eram valorizadas em outras formas de vida - tais como as dos comerciantes e outras que valorizavam e se envolviam com práticas de quantificação - quando atravessavam os muros da escola e se conformavam aos propósitos sociais da forma de vida da escola:

O ensino de aritmética foi introduzido nas escolas elementares britânicas, por volta de 1750 , e trazido para dentro da escola a partir do mercado. O currículo consistia no que Cohen chama "matemática concreta" sistemas de pesos, medidas e seus equivalentes, para diferentes ramos do comércio. O comércio fornecia os meios de estruturação para o currículo escolar, organizando atividades cotidianas de professores e crianças. [...] Por volta de 1820, o currículo de matemática nos Estados Unidos já não se parecia tanto com um levantamento das práticas quantitativas do mundo dos ofícios e do comércio, e começou a assumir uma estrutura institucionalizada própria (lições de matemática sobre adição, depois subtração, multiplicação e regra de três). O currículo já não era mais organizado especificamente em termos mercantis, embora ainda estivesse sujei- 
to a controvérsias devido às suas conexões comerciais (LAVE, 2003, p. 99).

Entretanto, talvez fazendo uma leitura bastante diferenciada da história em relação a que aqui fizemos, foi com base no estabelecimento de uma persuasiva analogia ecológica entre, por um lado, as relações mútuas que os seres vivos estabelecem entre si e com os diferentes ecossistemas em que vivem e sobreviverem e, por outro lado, os diferentes modos como os "organismos" matemáticos se organizam, interagem e sobrevivem em três diferentes "ecossistemas" - o sistema de ensino; o mundo da esfera sábia, erudita ou acadêmica; e a "noosfera" ou mundo dos que praticam ou organizam o ensino e/ou o tomam como objeto de reflexão e investigação - , que o educador matemático francês Yves Chevallard produziu a sua dinâmica "teoria da transposição didática", apresentando-a em sua influente obra intitulada La transposition didactique: $d u$ savoir savant au savoir enseigné, originalmente publicada em 1985 (CHEVALLARD, 1991).

A despeito, porém, do uso de uma terminologia inovadora e contemporânea para basear a sua explicação do fluxo "migratório" de um "saber matemático" do "ecossistema" sábio, erudito ou científico para a esfera do ensino bem como das transformações (deformações, restrições, adaptações didáticas etc.) pelas quais passa o "saber sábio" a fim de se tornar um "saber a ser ensinado" ou transmitido na escola -, a teoria da transposição didática de Chevallard logo passou a receber inúmeras críticas.

Na polêmica que o eminente pesquisador francês Andre Chervel estabeleceu com as ideias defendidas por Chevallard, ele defendeu o ponto de vista de que as disciplinas escolares - e, portanto, também a disciplina escolar "matemática" - não poderiam ser vistas como reflexos, vulgarizações ou meras adaptações de saberes produzidos no domínio dito "científico" das ciências de referência. Num breve texto intitulado "L'école, lieu de production d' une culture" (CHERVEL, 1992), Chervel se confronta explicitamente com as ideias de Chevallard (1992, p. 197):

Meu ponto de partida é bem diferente do de Chevallard, o que explica, talvez, uma parte de nossas divergências. Ele é um matemático, preocupado com a didática da matemática. Eu sou um investigador da língua francesa, ou melhor, um gramático, e tenho trabalhado, há quinze ou vinte anos, não com a didática de minha disciplina, mas com sua história: há, portanto, entre nós uma dupla diferença. [...] Minhas pesquisas não confirmam em nada a existência de um grupo social independente da escola, cuja função seria a de transformar o saber erudito em saber ensinável. Ao contrário, elas me levam a ver na escola (em sentido amplo) um lugar de produção de cultura, de uma cultura escolar, de conteúdos de ensino, de "disciplinas". É preciso, portanto, apresentar um outro quadro teórico no qual se possa conceber a escola como criadora de "conte- 
údos culturais". Mas é preciso, antes de mais nada, delimitar o domínio: aquele em que os ensinamentos são "disciplinas", isto é, conteúdos direcionados às crianças ou aos adolescentes em um processo que não é somente um processo de instrução, mas também de educação.

Como se nota, à noção ainda que dinâmica e ecologicamente situada de "saber" mobilizada por Chevallard, a qual se mantém, porém, ideologicamente neutra ao longo de sua trajetória migratória, Chervel contrapõe a noção disciplinar e disciplinadora de "conteúdos culturais", os quais são política e valorativamente transfigurados ao longo de suas apropriações ideológicas pela cultura escolar. Chervel (1992) nos fornece um exemplo do modo como a cultura escolar opera um tal tipo de transfiguração ideológica:

Os colégios clássicos do Antigo Regime transformaram Cícero e a literatura romana pagã nos precursores do monoteísmo cristão. Assim, a primeira frase, tomada de empréstimo a Cícero, do Selectae e profanis scriptoribus ("Selecionados entre os escritores pagãos" - manual elaborado para a sexta série pelo professor Heuzet, em 1726, e ainda utilizada durante todo o século XIX) é a seguinte: Animal nullum est, praeter hominem, quod habeat notitiam aliquam Dei ("Não existe animal algum, com exceção do homem, que tenha a menor noção de Deus"). Cícero tinha, evidentemente, escrito e pensado "dei" ("de um deus"). Ao mesmo tempo em que se aprende o latim de Cícero, aprende-se também que Cícero é um monoteísta! Trata-se, incontestavelmente, de um ensino; mas se trata de um "saber"?

A palavra disciplina, como afirma Chervel, só recentemente tem sido objeto de consideração e reflexão mais aprofundada:

Demasiado vagas ou demasiado restritas, as definições que dela são dadas de fato não estão de acordo a não ser sobre a necessidade de encobrir o uso banal do termo, o qual não é distinguido de seus "sinônimos", como "matérias" ou "conteúdos" de ensino. A disciplina é aquilo que se ensina e ponto final. [...] A história da palavra 'disciplina' (escolar) e as condições nas quais ela se impôs após a Primeira Guerra Mundial colocam contudo em plena luz a importância deste conceito, e não permitem confundi-lo com os termos vizinhos. No seu uso escolar, o termo "disciplina" e a expressão "disciplina escolar" não designam, até o fim do século XIX, mais do que a vigilância dos estabelecimentos, a repressão das condutas prejudiciais à sua boa ordem e aquela parte da educação dos alunos que contribui para isso. No sentido que nos interessa aqui, de "conteúdos do ensino", o termo está ausente de todos os dicionários do século XIX, e mesmo do Dictionnaire de l'Academie de 1932 (CHERVEL, 1990, p. 177).

No seu já clássico texto intitulado História das disciplinas escolares: reflexões sobre um campo de pesquisa, do qual extraímos a consideração acima sobre a pala- 
vra 'disciplina', Chervel esclarece ainda mais o uso que faz desta palavra que, para ele, define a identidade e a singularidade da cultura escolar em relação à cultura produzida em outros contextos institucionais:

Os conteúdos de ensino não são vulgarizações ou adaptações. Uma disciplina é, para nós, um modo de disciplinar o espirito, de lhe dar os métodos e as regras para abordar os diferentes domínios do pensamento, do conhecimento e da arte. Uma disciplina escolar comporta não somente as práticas docentes da aula, mas também as grandes finalidades que presidiram sua constituição e o fenômeno de aculturação de massa que ela determina. [...] O sistema escolar desempenha um duplo papel criativo na sociedade: ele forma não somente os indivíduos, mas também, uma cultura que vem por sua vez penetrar, moldar, modificar a cultura da sociedade global. [...] $A$ escola tem uma função educativa. Apenas em parte ela se obriga a dar uma instrução. Essa instrução está inteiramente subordinada à função educativa, ou ao ramo estudado. As disciplinas escolares estão no centro desse dispositivo. Sua função consiste, em cada caso, em colocar um conteúdo de instrução a serviço de uma finalidade educativa (CHERVEL, 1990, p. 184).

Nessa polêmica, penso que Chervel tem razão quando insiste no fato de que uma disciplina escolar não se constitui e nem se institui como o foco da política curricular dos processos modernos de escolarização de massas através do modo como a teoria da transposição didática de Chervel descreve a constituição e instituição de tais processos, isto é, meramente para se contemplar ajustes transpositivos de saberes ditos "científicos" de modo a torná-los didaticamente adaptados para serem ensinados. Ainda que a forma de vida escolar tivesse, sim, realizado ajustes didáticos dessa natureza, penso não terem sido apenas tais ajustes que, historicamente, estiveram na base da transfiguração disciplinar reducionista, abstracionista e conteudista por que passaram as práticas sociais encenadas por jogos de linguagem em diferentes formas de vida quando "transpuseram" os muros da escola.

Mas, se é através de transfigurações reducionistas, abstracionistas e conteudistas das práticas, e da posterior reorganização das mesmas em rótulos disciplinares diferentes que as demais formas humanas de vida se produzem e se reproduzem, devemos, então, nos perguntar: em que espaços ou lugares, em que campos de atividade humana, em que "ambientes", "ecossistemas" ou "formas de vida" o conhecimento reivindica ver-se organizado - ou, de fato, se organiza - em disciplinas ou áreas de conhecimento? Devemos também nos perguntar, ainda mais radicalmente: onde estão os "conhecimentos em si", os "saberes em si", desligados dos problemas que os constituem, das comunidades que os instituem como saberes legítimos ou pertinentes para o enfrentamento de tais problemas e das práticas sociais que os mobilizam nos diferentes campos de atividade humana nos quais tais problemas emergem? A resposta é uma só: "conhecimentos" ou "saberes em si" - conformados em disciplinas ou áreas 
distintas de conhecimento - só são mesmo mobilizados desse modo em uma única forma de vida humana, qual seja, a instituição escolar em todos os seus níveis, incluindo o superior. E por que apenas na escola os saberes necessitariam mostrar-se compartimentados, ordenados, hierarquizados?

A primeira opção política que esteve na base da organização da escolarização moderna foi a de instituir uma educação pública intencional, sistemática, separada e independente de quaisquer outras formas humanas de vida que também educam os sujeitos de um modo não intencional e assistemático, tais como o fazem, por exemplo: as instituições familiares, religiosas, midiáticas, sindicais, os partidos políticos, dentre outras. Tal opção se mostrou ideológica em relação ao problema da educação e da formação do cidadão. Isso porque, a opção de apartar radicalmente a forma de vida da escola das demais formas de vida veio acompanhada da promessa ilusória de que a escola prepararia simultaneamente os indivíduos para a sua inserção no processo civilizatório, para o trabalho em diferentes campos de atividade humana, para o exercício da cidadania e para a sua realização pessoal. Em suma, a forma de vida escolar moderna se constituiu orientada pelo propósito de se preparar "humanos" para a inserção socialmente qualificada em todas as esferas em que se organiza a "vida humana".

Mas uma outra opção política - também de natureza ideológica ainda mais visível - acompanhou o advento de nossos sistemas modernos de escolarização, qual seja, a de se constituir e instituir uma forma de vida escolar com base em uma ética biopolítica que transfigurou um direito político do cidadão à educação pública e gratuita em um tipo de obrigação em envolver-se com (ou contra) os demais cidadãos - constituídos com o mesmo direito - numa luta individualista, etapista, seriada, uniformizadora, concorrencial, meritocrática, seletiva, propedêutica e excludente.

Assim, desde o início, a ética biopolítica de cunho liberal-meritocrático - e, mais recentemente, de cunho neoliberal-meritocrático - vem normatizando, invariavelmente, a formação escolar do cidadão, colocando-o compulsoriamente a serviço de formas capitalistas de organização da vida do e no trabalho e do trabalho na vida. Entretanto, tal ética biopolítica que normatiza a forma de vida de humanos na escola conflita diretamente com a ética biopolítica de formas democráticas de vida, pois estamos aqui mobilizando a palavra "democracia" num sentido amplo que a entende não só como uma reivindicação de democracia política, social e econômica nas relações que se estabelecem entre os indivíduos e a forma de vida Estado-Nação à qual eles pertencem, como também, nas relações que se estabelecem entre humanos e não humanos em todas as forma de vida, bem como nas relações interativas que se estabelecem entre formas de vida diversas.

Mas uma terceira opção - agora de natureza político-epistemológica que acompanhou o advento de nossos sistemas modernos de escolarização foi a implantação de políticas curriculares baseadas em uma concepção de conheci- 
mento que o vê como um conjunto cumulativo de conteúdos tidos como científicos, universais, objetivos, verdadeiros, neutros ou não polêmicos e desligados das práticas e das formas de vida nas quais eles são mobilizados. Além disso, esse modo cientificista de se conceber o conhecimento levou tais políticas curriculares a conceberem e a organizarem o ensino e a aprendizagem segundo uma matriz disciplinar, desenvolvimentista, etapista, psicologizante, estritamente cognitivista e conceitual. Tudo isso com base na crença retrógrada de existência de uma suposta correspondência objetiva entre a distribuição temporalmente seriada de conteúdos disciplinares, habilidades e competências e supostas etapas do desenvolvimento mental dos humanos.

Desse modo, a modernidade inventou não só a epistemologia - isto é, a possibilidade de se falar em conhecimento humano autônomo e independente tanto da natureza, quanto da linguagem e, por extensão, a possibilidade de se teorizar sobre o conhecimento assim autonomizado -, como também recortou, inicialmente, o estudo do conhecimento em um sem número de campos disciplinares especializados - igualmente separados e autônomos -, voltando, posteriormente, a conectar tais disciplinas em um número suficientemente conveniente de "áreas de conhecimento", vistas como "interdisciplinares", a ponto de não ameaçarem a conveniência da manutenção do contrato constitucional unilateral que instaurava, por um lado, os direitos políticos de "humanos culturalmente ativos" transformados em cidadãos nacionalizados em territórios geograficamente delimitados e inesgotavelmente exploráveis e, por outro lado, os "deveres" apolíticos e apartidários de "nãohumanos- objetos naturais culturalmente passivos", vistos como pedaços planetários da mãe-Terra eternamente fértil, dócil e colonizável.

Tendo, adicionalmente, como "suporte científico" a então emergente teoria da evolução de Darwin, da qual, indevida e imprudentemente, se inferiu que as transformações concorrenciais acidentais entre as diferentes "espécies naturais" se punham, todas, a serviço dos "humanos" privilegiadamente concebidos como o seu melhor "desejo estético de acabamento", não é, portanto, de se surpreender que todos os sistemas modernos de escolarização pública que se alastraram pelo mundo ocidental, sobretudo a partir do século XIX, tivessem metaforicamente se inspirado no modelo da "escada sem apoio na terra ou no céu" para organizarem os seus sistemas nacionais de educação pública.

Rorty tinha, sim, razão quando, em sua polêmica com Wilson, disse que as disciplinas acadêmicas - como também as escolares, acrescentaríamos nós - não são reflexos do mundo, isto é, dos modos como a vida diversamente se constitui, se organiza e se transcorre em uma multiplicidade de formas de vida que interagem diversamente entre si, com ritmos e intensidades diferenciados e com base em diferentes interesses propósitos sociais, na maior parte das vezes conflitantes entre si. Mas é justamente com base em argumento análogo a este de Rorty - isto é, por não dialogar com a vida, com essas diferentes formas de vida - que as disciplinas escolares não constituem, em seu conjunto ou em 
suas interações, um modo politicamente consequente, ajustado e desejável para se formar o cidadão descolonizado, promotor vigilante da democratização social, política e econômica de todas as nossas formas de vida.

É por essa e por todas as demais razões que aqui já expusemos, que temos defendido, para a educação básica, políticas curriculares indisciplinares que desloquem o foco de suas ações educativas da exposição e memorização de conteúdos conceituais disciplinares seriados e sequencialmente organizados para o da problematização terapêutico-desconstrucionista e indisciplinar do trânsito de uma prática social - encenada como um jogo de linguagem entretecido em uma forma de vida - por diferentes formas de vida.

Problematizações terapêuticas dessa natureza nada têm a ver com doutrinação política, ideológica, partidária, científica, religiosa ou de qualquer outra natureza. Toda forma de doutrinação é sempre uma forma dogmática, autoritária e colonizadora de educação e esse tipo de educação ou formação escolar é incompatível com uma verdadeira escola democrática. Mas, infelizmente, por força de políticas educacionais e curriculares autoritárias, é este tipo de escolarização dogmática que tem sido praticada em nossas escolas. Cabe, portanto, a uma escola democrática que investe na formação de cidadãos descolonizados, abrir-se à problematização terapêutica dialógica e não dogmática de todas as práticas extraescolares que se realizam em diferentes formas de vida humana, sejam tais práticas ditas "científicas" ou não, eticamente reprováveis ou não, criminalizadas ou não.

\section{Referências}

CASTRO, E. V. de. Metafísicas canibais: elementos para uma antropologia pós-estrutural. 1. ed. São Paulo: Cosac Naify, 2015.

CHERVEL, A. História das disciplinas escolares: reflexões sobre um campo de pesquisa. In: 1990, p. 177-229. Teoria \& Educação. 2. ed. Porto Alegre: Pannonica.

. L'école, lieu de production d'une culture. In: AUDIGER, F.; BAILLAT, G. (Ed.). Actes des rencontres sur la didactique de l'histoire, de la géographie, des sciences économiques et sociales. Paris: INRP, 1992. p. 195-198.

CHEVALLARD, Y. La transposición didáctica: del saber sabio al saber enseñado. Argentina: Aique Grupo Editor, 1991.

FOUCAULT, M. A ordem do discurso. 2. ed. São Paulo: Edições Loyola, 2004.

LATOUR, B. Jamais fomos modernos: ensaio de antropologia simétrica. 3. ed. Tradução de Carlos Irineu da Costa. São Paulo: Editora 34, 2013. 
Reensamblar lo social: una introducción a la teoria del actor-red. 1. ed. Buenos Aires: Manantial, 2008.

LAVE, J. Cognition in Pratice: Mind, Mathematics and culture in everyday life. Cambridge: Cambridge University Press, 2003.

MIGUEL, A. Áreas e subareas do conhecimento, vínculos epistemológicos: o GT de Educação Matemática da ANPEd. Revista Brasileira de Educação, v. 13, n. 38, p. 387-396, maio/ago. 2008.

Is the mathematics education a problem for the school or is the school a problem for the mathematics education? Brazilian Society for Mathematics Education: International Journal for Research in Mathematics Education, v. 4, n. 2, p. 5-35, 2014.

READ, R. Filosofia aplicada: Política e cultura no mundo contemporâneo. Organização de M. A. Lavery. Tradução de Rogério Bettoni. 1. ed. São Paulo: Edições Rosari Ltda., 2009.

RORTY, Richard. Contra a unidade. Jornal Folha de São Paulo, Caderno Mais, 22/03/1998, p. 7-8.

SAIDAN, A. S. The Arithmetic of al-Uqlīdisī. The Story of Hindu-Arabic Arithmetic as told in Kitāb al-Fuṣūl fī al-Hisāb al-Hindī. Translated and annoted by A. S. Saidan. Dordrecht: D. Reidel Publishing Company, 1975.

SOUZA, E. S. A prática social do cálculo escrito na formação de professores: a história como possibilidade de pensar questões do presente. Tese (Doutorado) - Faculdade de Educação, Universidade Estadual de Campinas, Campinas, 2004.

SWETZ, F. Capitalism and Arithmetic. The New Math of 15th Century. Illinois: Open Court Publishing Company, 1989.

WILSON, E. O. A unidade do conhecimento: consiliência. Rio de Janeiro: Campus, 1999.

WITTTGENSTEIN, L. Cultura e valor. Lisboa: Edições 70, 2000.

Philosophical investigations. Translated by Elizabeth Anscombe, Peter Hacker and Joachim Schulte. Revised by Peter Hacker and Joachim Schulte. 4. ed. United Kingdom: Blackwell Publishing Ltd., 2009.

Investigações filosóficas. Tradução de José Carlos Bruni. São Paulo: Nova Cultural, 1979. 



\title{
MATEMÁTICA, ÁREA DE CONHECIMENTO E EDUCAÇÃO*
}

\author{
Maria Helena Soares de Souza
}

Para pensar a Matemática como área de conhecimento, é preciso partir do próprio conhecimento e de seu desenvolvimento na história da humanidade. Como o conhecer é fruto de operação obtida pela razão, mas também pelos afetos, faz-se necessário reconhecer, tendo em vista que a inteligência humana é múltipla e todo ser humano é ser social, artístico, lógico, afetivo e político, que seja integral, abarcando todas as áreas de conhecimento e as linguagens. O pensamento, em busca do conhecimento, esquadrinha a realidade pela análise, classificação e categorização, pelo reconhecimento de seus elementos, pela nomeação dos fenômenos e pela organização.

O progresso ${ }^{1}$ do conhecimento, sobretudo durante o século $\mathrm{XX}$, trouxe significativo desenvolvimento das ciências, promovendo bem-estar social em situações de pós-guerras, com a especialização do saber e das ferramentas tecnológicas. Dessa forma, advieram avanços na medicina que salvam vidas, o aumento das possibilidades de alimentar um maior número de pessoas, mas, em contrapartida, surgiu a possibilidade de destruição em massa, fruto do conhecimento das tecnologias armamentistas, inclusa a bomba atômica, ou a deterioração constante do meio ambiente que se estendeu ao século XXI. O poder econômico, marcado pela desigualdade entre os povos, aumentou consideravelmente a pobreza mundial, o consumo desenfreado e destrutivo, e o conhecimento científico hegemônico.

Nesse quadro, os diversos povos espalhados pelo globo terrestre começaram a perder suas identidades próprias e culturas identitárias, absorvidos pelas culturas hegemônicas, sob estado de esvaziamento político. A tomada de consciência começa na década de 1960, ao ficar claro que as ciências isoladas não permitiam conhecer verdadeiramente os seres vivos, humanos ou não, porque são marcadas pela fragmentação do conhecimento, o sempre dividir para compreender, o especializar-se ao extremo para conceber. A vida humana, individual ou social, não pode ser explicada ou justificada pelo esfacelamento do saber, pois é bem mais complexa do que a soma das partes. Sua explicação, como fenômeno e sentido, só pode se dar em vista do processo de compreender, mostrar causas, nomear elementos que não esgotam o conhecimento. É preciso considerar como parte desse mesmo processo, o encantamento, o permear o que se conhece pelas questões filosóficas. O diálogo entre as ciências e as lin-

\footnotetext{
*DOI - 10.29388/978-85-53111-95-4-0-f.43-48

${ }^{1}$ Nos anos 1950 há modificação do conceito de progresso, que se abre para duas frentes: o moral e espiritual de um lado e o tecnológico e científico de outro. (SACRISTÁN, 1998)
} 
guagens deve estar presente na formação de valores éticos, políticos, estéticos, de convívio, atrelados aos sonhos e às utopias. Para que esse diálogo aconteça, é preciso libertar os componentes curriculares compartimentados das escolas, entre eles a Matemática, ampliá-los para área de conhecimento e pensar os conhecimentos científicos.

Como ciência e poder no homem coincidem (BACON, 1979), há que se clamar pelo progresso científico atrelado a ética, como quer Jonas (2006). A visão da Matemática como área de conhecimento ultrapassa a da tecnologia aliada à ciência pela proposta de viabilidade humanizadora da ética, que deve ser força e suporte da Educação Matemática. A Matemática é ciência, mas também ferramenta e, de certa forma, linguagem conectada com as demais, sobretudo as artísticas, com o suporte de ideias que são seus fundamentos, como a proporcionalidade, a periodicidade ou a equivalência, que transbordam de seus muros e compõem as demais áreas de conhecimento. Sob este primeiro guarda-chuva estão os contextos sociopolíticos, sabido que o conhecimento matemático é construído pelas práticas sociais.

É preciso inserir a Matemática para expandi-la como área de conhecimento, em metodologias ativas e rigorosas, seja na construção do pensamento com dimensão tanto social e grupal como individual, até a organização de espaços arquitetônicos e também dos lúdicos, de lazer e convivência, da disponibilidade de tecnologias da comunicação até o estabelecimento de trabalhos e ações sociais em grupos de diferentes culturas, origens étnicas e de gênero. Somem-se a isso os conteúdos facilitadores que instrumentalizem o debate entre as artes, a experimentação científica fundada em princípios éticos, as vivências e convivências grupais e internacionais, em redes de cooperação e de projetos em comum. A Matemática reúne um conjunto de conhecimentos inter-relacionados, que foram construídos de forma coletiva, uma vez que o conhecimento adquirido é pessoal, não individual, e expande-se para domínio coletivo a partir da pes soa. Tais conhecimentos podem, inclusive, sofrer segmentação em função da submissão a estudos e a procedimentos metodológicos, se forem objetos de ensino e aprendizagem.

Aprender Matemática em associação com escolas, professores e gestores, pede que tais atores cumpram seu papel fundamental, que é o da abertura para o diálogo e o reconhecimento filosófico do debate e da criação de projetos educacionais humanizadores, com intermediações processuais do conhecimento buscadas em sua dimensão social e pessoal. As vivências de alunos e professores criadas no diálogo da e na escola, na comunidade escolar e em seu entorno social, buscam a interdisciplinaridade e a ampliação do conceito de disciplina ou componente curricular para área de conhecimento. Por isso, não é teoria ou discurso, mas prática em projeto problematizador de questões, que envolvem o conhecimento e sua íntima ligação com o projeto humano e digno de toda sociedade, de cada pessoa em particular. A área de conhecimento é construção 
mental, pelo desenvolvimento pessoal de indivíduos que vivenciam valores e ideias acerca da vida.

O processo de encontro e de convivência com diversas culturas, proporciona momentos de curiosidade, criativos e novos, muitos conflitantes, mas que permitem o enriquecimento, tendo como ponto de partida interações que possam reduzir discriminações e dominações pelo exercício abusivo do poder.

Embora o conhecimento seja gerado individualmente, a partir de informações recebidas da realidade, no encontro com o outro se dá o fenômeno da comunicação, talvez a característica que mais distingue a espécie humana das demais espécies. Via comunicação, as informações captadas por um indivíduo, que é resultado do processamento da totalidade das informações disponíveis, são, também via comunicação, compartilhado, ao menos parcialmente, com o outro. Isso se estende, obviamente, a outros e ao grupo. Assim, desenvolve-se o conhecimento compartilhado pelo grupo. (D'AMBROSIO, 2001, p. 32).

A área de conhecimento Matemática pode ser um forte vetor de promoção de igualdade social, pelo seu poder de comunicação, por suas ideias e por ser ferramenta indispensável para as ciências. Além disso, desempenha um papel fundamental na organização do pensamento pelo desenvolvimento de raciocínio específico, como observar, estabelecer relações entre objetos, fatos e conceitos, generalizar, prever, projetar e abstrair. É possível destacar, nessa área de conhecimento, os eixos, ditos estruturantes, que advêm de ideias organizadoras, como o número, a forma, o movimento, as grandezas e as medidas e o acaso, todas ligadas entre si (STEWART, 1996). Eixos e ideias precisam ser problematizados e conectados à história da humanidade, incluindo a história da Matemática, que mostra caminhos em busca de soluções.

Como área de conhecimento, a Matemática e seu ensino, precisam reconhecer a distância entre a Matemática escolar e a abstrata, muitas vezes desvinculada do mundo real. Há, por exemplo, diferenças entre o espaço físico, habitado por todos, e o geométrico. Determinadas medidas de comprimento escolares não levam em conta, como os topógrafos operam, em consideração que a Terra não é plana e que é necessário sempre utilizar aproximações entre as diversas formas de conceber a Matemática.

Trazendo o mais possível para o presente, é preciso visualizar o ensino da Matemática, concebida como área de conhecimento e direito de todos, baseado nos direitos humanos que, segundo Bobbio (1992, p. 5) “[...] por mais fundamentais que sejam, são históricos, ou seja, nascidos em certas circunstâncias, caracterizadas por lutas em defesa de novas liberdades contra velhos poderes, e nascidos de modo gradual [...]".

Em relação aos direitos humanos, em face do desenvolvimento científico-tecnológico frente às transformações ambientais, econômicas e sociais, a ampliação do conhecimento e a intensificação dos meios de comunicação, hou- 
ve a necessidade de surgimento de novas demandas de liberdade e de poderes. Direitos humanos não são produtos da natureza, mas da civilização humana e, portanto, mutáveis - porque são históricos, podem ser ampliados e transformados. Eles são heterogêneos, pois há pretensões diversas contidas neles e até mesmo incompatíveis entre si. A realização de uns impede a realização integral de outros. Quanto mais aumenta os poderes dos indivíduos, tanto mais diminuem/relativizam-se as liberdades individuais e coletivas. Os direitos humanos fundamentais são absolutos, mas os demais são relativos. Para esses é preciso até mesmo impor limites, como acontece com a liberdade em fazer determinadas pesquisas científicas biológicas que envolvem seres humanos, por exemplo.

O caráter dos direitos humanos - que têm surgido quando novas necessidades nascem em decorrência de mudanças das relações sociais -, categorizados em quatro gerações distintas, conforme as aspirações da sociedade em determinado momento de seu desenvolvimento, é histórico. No entanto, para a discussão proposta focam-se as duas primeiras gerações de direito para maior atenção, tomada por base a educação.

Os direitos de Primeira Geração remontam ao século XVIII, em consequência da proclamação das liberdades individuais e da igualdade de todos perante a lei, durante o período da independência das treze colônias inglesas na América do Norte e do processo histórico da Revolução Francesa. São os direitos de liberdade que, para Bobbio (1992), tendem a limitar o poder do Estado e a reservar para o "homem" ${ }^{2}$ ou cidadão, ou para os grupos particulares, uma esfera de autonomia de decisão, de modo a resguardar as liberdades públicas, sem interferência do arbítrio estatal sobre os direitos individuais, cujo objeto é a conduta de agir ou não agir, fazer ou não fazer, usar ou não usar, ir, vir ou ficar.

Os da Segunda Geração deflagram os direitos sociais e políticos, que surgiram com o término da Primeira Guerra Mundial. Do liberalismo econômico e político resultou a geração de riquezas de um lado e, de outro, o empobrecimento da classe trabalhadora ${ }^{3}$. As diferenças entre ricos e pobres foram acentuadas e a mão-de-obra praticamente substituída pelas máquinas, aumentando o desemprego e acentuando a desigualdade social. Os direitos sociais, que requerem intervenção direta do Estado, expressam o amadurecimento de novas exigências, de novos valores como os do bem-estar e da igualdade, não apenas formal, que poderiam ser chamadas de liberdade por meio do Estado, e constituinte da ação positiva estatal. Tais direitos concebem a liberdade como autonomia e a participação, cada vez maior e frequente, dos membros da comunidade no poder político.

Os direitos de Primeira e de Segunda Gerações foram ampliados pela Declaração Universal dos Direitos do Homem, promulgada pela Assembleia Geral das Nações Unidas em 1948, da qual o Brasil é signatário. Trata-se de

\footnotetext{
${ }^{2}$ A palavra homem consta dos direitos da Virgínia de 1776.

${ }^{3}$ Conferir a Primeira Parte: renda e capital pp. 43 - 111, do livro O Capital no Século XXI, de PIKETTI, Thomas. Trad. Monica Baumgarten de Bolle. Rio de Janeiro: Intrínseca, 2014.
} 
uma síntese, em que lado a lado se inscrevem os direitos fundamentais, ditos da Primeira Geração - as liberdades - e os da Segunda Geração - os direitos sociais. A Educação como um direito de todos traduz a ideia de que, reconhecidamente, é direito formalmente constituído.

A Educação para todos como princípio, perspectivada pelos direitos humanos, significa levar às últimas consequências a ideia como um direito constitucional. Trata-se de direito sob o qual os novos seres têm de participar da herança simbólica pública e assim ser novo no mundo por processos educativos. Nesse contexto, insere-se a Educação Matemática, a Matemática como área de conhecimento e os direitos de aprendizagem, que saem da mera espera de conhecimentos alcançados para o direito de adquiri-los.

O que se propõe é a compreensão do passado e o estabelecimento de vínculos com o presente, em busca da construção de um futuro em que ocorram transformações sociais que respeitem as diferenças pessoais, que promovam a equidade, a justiça e o equilíbrio social, que possam construir convivências solidárias e não excludentes.

\section{Referências}

BACON, F. Novum Organum ou Verdadeiras indicações acerca da Natureza. 2. ed. Tradução de José Aluysio Reis de Andrade. São Paulo: Abril Cultural, 1979. (Coleção Os Pensadores).

BOBBIO, N. A era dos direitos. 11. ed. Rio de Janeiro: Campus, 1992.

D’AMBROSIO, U. Etnomatemática: elo entre as tradições e a modernidade. Belo Horizonte: Ed. Autêntica, 2001.

JONAS, H. O princípio da responsabilidade: ensaio de uma ética para a civilização tecnológica. Tradução de Marijane Lisboa e L. Barros Montez. Rio de Janeiro: Contraponto, PUC Rio de Janeiro, 2006.

SACRISTÁN, J. G. Poderes Instáveis em Educação. Porto Alegre: Artmed, 1999.

STEWART, I. Problemas da matemática. 2. ed. Tradução de Miguel Urbano. Lisboa: Gradiva, 1996. 



\section{QUAL É O LUGAR DA MATEMÁTICA?*}

Cristina Cerri

Quais as implicações no ensino ao se reconhecer a Matemática como área de conhecimento, ultrapassando os limites de uma disciplina escolar?

Essa questão motivou o texto que apresento, com algumas reflexões sobre o conhecimento matemático e sua importância. Coloco também algumas considerações sobre como a Matemática é apresentada em documentos oficiais, que podem sugerir discussões sobre como essa área se insere no contexto escolar.

Primeiramente, como entender conhecimento matemático num contexto mais amplo? A organização do conhecimento humano em áreas atende a diversos propósitos e tem se refletido na educação e em propostas curriculares.

O conhecimento humano pode ser entendido como toda a experiência humana adquirida até o momento por meio de pensamentos, reflexões, criações e invenções da humanidade. É próprio da essência do homem questionar e procurar respostas sobre o ambiente em que vive, sobre sua própria existência e seus comportamentos, sobre os fenômenos da natureza e sobre tudo que puder imaginar. Devido a sua capacidade de enfrentar problemas e tentar solucionálos, o homem conseguiu produzir o fogo, inventar a roda, viajar até a Lua, construir a bomba atômica, criar o computador e a internet. Observar e pensar gera conhecimento, que pode ser e deve ser transmitido e apreendido e assim está sempre em expansão e evolução.

A organização do conhecimento é objeto de interesse e pesquisa de diversos pontos de vista, tendo sido estudado por filósofos, educadores, documentalistas, cientistas da informação, linguistas, dentre outros. Segundo Souza (2004) uma classificação de "áreas do conhecimento" permite "organizar de maneira sistemática dados da produção científica publicada e é instrumento de importância fundamental para as áreas de gestão e avaliação, assim como suporte representativo para a formulação, implementação, acompanhamento e avaliação de políticas públicas na área de Ciência e Tecnologia. Toda classificação está relacionada a um propósito e, portanto, pode ser alterada dependendo do contexto e dos objetivos, sofrendo influências culturais, sociais e políticas."

De qualquer forma, classificado ou não, o conhecimento acumulado pela humanidade precisa ser registrado e transmitido. Ao longo da história, civilizações desenvolveram suas maneiras próprias de registrar e assim perpetuar o conhecimento que tinham, com os recursos que disponham. Dessa forma gerações futuras puderam apreender o que havia sido produzido e evoluir, gerando novos conhecimentos. Neste contexto coloca-se a instituição escolar.

*DOI - 10.29388/978-85-53111-95-4-0-f.49-56 
A Escola tem como objetivo preparar a criança e o jovem para entender o mundo e a sociedade em que vive, compreender situações e fenômenos e assim tornar-se um ser socialmente ativo e participativo. Desempenha a função de desenvolver no aluno habilidades, valores, além de desenvolver capacidades para atuar na sociedade. É na escola que se tem contato com o conhecimento, onde as várias áreas do saber devem ser tratadas e conteúdos apreendidos, passando a se constituir em um saber individual. Isso permitiria a disseminação do conhecimento e o seu desenvolvimento.

Sobre o papel da Escola na formação do cidadão, os Parâmetros Curriculares Nacionais (PCN) do Ensino Fundamental (BRASIL, 1998, p. 33) trazem a seguinte afirmação:

A importância dada aos conteúdos revela um compromisso da instituição escolar em garantir o acesso aos saberes elaborados socialmente, pois estes se constituem como instrumentos para o desenvolvimento, a socialização, o exercício da cidadania democrática e a atuação no sentido de refutar ou reformular as deformações dos conhecimentos, as imposições de crenças dogmáticas e a petrificação de valores.

Cabe então a escola possibilitar o acesso aos conteúdos próprios da Matemática, entendida como área do saber fruto do desenvolvimento humano. Contudo, quais são os conteúdos e elementos da Matemática? Ou seja: o que é a Matemática?

Como fruto da atividade humana, o conhecimento dessa área do saber evoluiu a partir das necessidades básicas de comunicar e de descrever formas e fenômenos. Mesmo tendo raízes em necessidades práticas, o desenvolvimento dessa área foi possibilitado também por discussões de questões filosóficas, que transcendem a própria área.

A Matemática é, sem dúvida, essencial para a compreensão e o estudo de problemas científicos e tecnológicos. Contudo ela tem vida própria e avança também por meio de conjecturas e problemas dentro seu próprio contexto e com seus próprios elementos.

No livro "O que é a Matemática?", Richard Courant (COURANT; ROBBINS, 2000) inicia o prefácio, escrito em 1941, afirmando que: "A Matemática, como expressão da mente humana, reflete a vontade ativa, a razão contemplativa, e o desejo da perfeição estética. Seus elementos básicos são a lógica e a intuição, a análise e a construção, a generalidade e a individualidade".

E nos PCN da área de Matemática (BRASIL, 1998, p. 24), pode-se ler a seguinte caracterização:

Duas forças indissociáveis estão sempre a impulsionar o trabalho em Matemática. De um lado, o permanente apelo das aplicações às mais variadas atividades humanas, das mais simples na vida cotidiana, às mais complexas elaborações de outras ciências. De outro lado, a especulação 
pura, a busca de respostas a questões geradas no próprio edifício da $\mathrm{Ma}$ temática. A indissociabilidade desses dois aspectos fica evidenciada pelos inúmeros exemplos de belas construções abstratas originadas em problemas aplicados e, por outro lado, de surpreendentes aplicações encontradas para as mais puras especulações.

A Matemática é uma área do conhecimento, com seus próprios elementos e métodos de pesquisa, com interações e influências de outras áreas. Como, contudo, a Matemática é inserida no contexto escolar? Os vários aspectos dessa área do conhecimento estão representados ou são compreendidos?

Para procurar melhor organizar e estruturar o conhecimento e os conteúdos a serem tratados na escola, bem como, orientar professores e educadores da forma mais adequada de serem abordados, para as diferentes faixas etárias, muito se discutiu e se produziu. Ao longo do tempo, teorias e metodologias influenciaram gerações de educadores, autores de manuais e de livros didáticos.

Com relação ao ensino de Matemática foram muitas as inquietações e discussões. Importantes matemáticos se preocuparam com a forma que os conteúdos da área eram tratados. Um deles é Felix Klein (1849-1925), que publicou, em 1908, um livro tratando de temas da Matemática elementar de um ponto de vista avançado. Klein preocupou-se em dar orientações aos professores e afirmou que este deve sempre apresentar os conteúdos de uma forma intuitivamente compreensível. O objetivo de Klein na época foi escrever textos para dar subsídios aos professores secundários para que pudessem transmitir a riqueza da Matemática usando o currículo escolar. Nas suas palavras: "Minha tarefa será sempre mostrar-lhes a mútua conexão entre problemas em variadas áreas. Desta maneira, espero facilitar-lhes a aquisição da habilidade para obter da grande massa de conbecimento um estimulo vivo para seu ensino".

Outros matemáticos também se detiveram sobre questões do ensino de Matemática e promoveram grandes mudanças. Como exemplo podemos citar as reformas dos programas para o ensino das matemáticas "modernas" na França para o nível secundário (11-17 anos), fruto da Comissão Lichnerowicz, liderada pelo matemático André Lichnerowicz (1915 - 1998). As discussões promovidas por esta reforma e os efeitos da proposta da chamada "matemática moderna" influenciaram o ensino da área na França e também em outros países como no Brasil.

São muitos os exemplos que mostram a atenção dada com o ensino da Matemática, promovida, sobretudo, pela meta de inserção de todas as crianças sistema educacional. Sem dúvida sempre houve grande preocupação com a abordagem feita na escola, com a fragmentação demasiada e a falta de entendimento da Matemática como uma área em construção, fruto da atividade humana. São muitos os exemplos de propostas e tratados que abordam a preocupa-

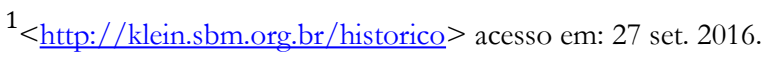


ção com a melhor transmitir a essência da Matemática, como também torná-la acessível. São recorrentes os problemas com o tratamento excessivamente compartimentado e pouco relacionado com outras áreas do conhecimento, bem como relações com elementos da própria Matemática. Sobre isso há uma conhecida fase de Lichenerowicz (1915 - 1998), citada por Morin (2001):

Nossa Universidade atual forma, pelo mundo afora, uma proporção demasiado grande de especialistas em disciplinas predeterminadas, portanto artificialmente delimitadas, enquanto uma grande parte das atividades sociais, como o próprio desenvolvimento da ciência, exige homens capazes de um ângulo de visão muito mais amplo e, ao mesmo tempo, de um enfoque dos problemas em profundidade, além de novos progressos que transgridam as fronteiras históricas das disciplinas.

Assim, uma rápida pesquisa mostra que vários dos problemas que hoje destacamos na forma de abordagem dos conteúdos da área foram sempre alvo de discussões e reflexões. Pesquisadores na área de Educação Matemática procuram estudar tais questões de forma mais sistemática. E pesquisas influenciam orientações pedagógicas, currículos e políticas públicas na área de educação.

Também as propostas curriculares sofrem influências de ordem econômicas, políticas e sociais, refletindo as demandas de uma sociedade.

Como exemplo, vamos citar como a área de Matemática é apresentada e abordada em algumas das propostas e documentos oficiais.

Nos PCN para o Ensino Fundamental são apresentadas oito áreas: língua portuguesa, matemática, ciências naturais, história, geografia, arte, educação física, língua estrangeira, com tratamentos individualizados, mas com exemplos de possíveis integrações em temas interdisciplinares. Tal distribuição é justificada: "optou-se por um tratamento específico das áreas, em função da importância instrumental de cada uma, mas contemplou-se também a integração entre elas". (BRASIL, 1998, p. 41).

Os PCN do Ensino Médio, publicado em 2000, apresentam uma divisão diferente de áreas: Linguagens, Códigos e suas Tecnologias, Ciências da Natureza, Matemática e suas Tecnologias e Ciências Humanas e suas Tecnologias, tendo como base a reunião de conhecimentos que se aproximam e se comunicam, possibilitando mais facilmente um trabalho interdisciplinar. Destaco um trecho do documento PCN+ Ensino Médio (BRASIL, 2000, p. 8) que procura justificar essa nova divisão das áreas do conhecimento, tendo em vista os objetivos do Ensino Médio.

O novo ensino médio, nos termos da lei, de sua regulamentação e de seu encaminhamento, deixa de ser, portanto, simplesmente preparatório para o ensino superior ou estritamente profissionalizante, para assumir necessariamente a responsabilidade de completar a educação básica. Em qualquer de suas modalidades, isso significa preparar para a vida, qualificar 
para a cidadania e capacitar para o aprendizado permanente, em eventual prosseguimento dos estudos ou diretamente no mundo do trabalho.

A Matemática nesta etapa do ensino é vista como forma de ajudar o aluno a estruturar o pensamento e o raciocínio dedutivo, mas também como ferramenta para a vida cotidiana e para muitas tarefas específicas em quase todas as atividades humanas. A Matemática aproxima-se mais claramente das chamadas ciências da natureza: Biologia, Física e Química. É enfatizado o papel da Matemática como instrumento para uma construção mais abstrata nas ciências, bem como para a atividade humana.

Possivelmente, não existe nenhuma atividade da vida contemporânea, da
música à informática, do comércio à meteorologia, da medicina à carto-
grafia, das engenharias às comunicações, em que a Matemática não com-
pareça de maneira insubstituível para codificar, ordenar, quantificar e in-
terpretar compassos, taxas, dosagens, coordenadas, tensões, frequências
e quantas outras variáveis houver (BRASIL, 2000, p. 9).

Contudo, o documento também enfatiza que os processos de construção e validação próprios da área, bem como os procedimentos de relacionar, generalizar e concluir, permitem estabelecer relações e interpretar fenômenos e informações.

A Proposta Curricular do Estado de São Paulo para o Ensino Fundamental - Ciclo II e Ensino Médio, publicada em 2008 (SÃO PAULO, 2008), apresenta os conteúdos propostos distribuídos em quatro áreas: área de Ciências Humanas e suas Tecnologias; Ciências da Natureza e suas Tecnologias; Linguagens, Códigos e suas Tecnologias e Matemática e as áreas do conhecimento. Na proposta é explicitada a importância e a relevância de se colocar a área de matemática de forma separada: "destaca-se o fato de que uma parte da especificidade da Matemática resulta esmaecida quando ela é agregada seja ao grupo das linguagens em sentido amplo, ou seja, ao grupo das ciências" (SÃO PAULO, 2008, p. 38). E ainda é reforçado que "a apresentação da Matemática como uma área específica não pretende amplificar suas supostas peculiaridades nem caracterizá-la como um tema excessivamente especializado ou relevante" (SÃO PAULO, 2008, p. 39).

Examinar outra classificação encontrada no país, muito importante atualmente, pode vir a contribuir para o debate. Em 1998 foi criado o Exame Nacional do Ensino Médio (ENEM), com o objetivo de avaliar o desempenho do estudante ao fim da educação básica, buscando contribuir para a melhoria da qualidade desse nível de escolaridade. A partir de 2009 passou a ser utilizado também como mecanismo de seleção para o ingresso no ensino superior. A prova passou a cobrar o conteúdo do Ensino Médio dividido em quatro áreas do conhecimento: Linguagens, Códigos e suas Tecnologias; Ciências Humanas 
e suas Tecnologias; Matemática e suas Tecnologias e Ciências da Natureza e suas Tecnologias.

Diferentemente da organização feita no PCN do Ensino Médio, para efeitos dessa avaliação a Matemática passou a ser uma área separada da de Ciências da Natureza. O exame tem como referência 5 (cinco) eixos cognitivos: dominar linguagens, compreender fenômenos, enfrentar situações-problema, construir argumentação e elaborar propostas. E na matriz de referência da área de Matemática e suas Tecnologias são descritas as "competências de áreas":

- Construir significados para os números naturais, inteiros, racionais e reais.

- Utilizar o conhecimento geométrico para realizar a leitura e a representação da realidade e agir sobre ela.

- Construir noções de grandezas e medidas para a compreensão da realidade e a solução de problemas do cotidiano.

- Construir noções de variação de grandezas para a compreensão da realidade e a solução de problemas do cotidiano.

- Modelar e resolver problemas que envolvem variáveis socioeconômicas ou técnico-científicas, usando representações algébricas.

- Interpretar informações de natureza científica e social obtidas da leitura de gráficos e tabelas, realizando previsão de tendência, extrapolação, interpolação e interpretação.

- Compreender o caráter aleatório e não-determinístico dos fenômenos naturais e sociais e utilizar instrumentos adequados para medidas, determinação de amostras e cálculos de probabilidade para interpretar informações de variáveis apresentadas em uma distribuição estatística.

Universidades públicas e privadas adotam o ENEM nos seus processos seletivos e assim influência e impacta a formação dos jovens e os currículos de cursos de ensino médio pelo país. A forma de avaliação, procurando avaliar as competências listadas, enfatiza a Matemática dentro de contextos da realidade e como linguagem do mundo e da ciência. Seriam estes os principais aspectos da Matemática a serem destacados e avaliados?

O conhecimento Matemático, como conhecimento gerado pela humanidade, pode ou deve ser apresentado e discutido na escola, assim como outros. Apesar das enormes evoluções na área, os conteúdos abordados nos vários segmentos de ensino básico sofreram poucas alterações. Os avanços tecnológicos. Além disso, as principais ideias, norteadoras das descobertas e do desenvolvimento, são pouco destacadas.

Atualmente, graças ao desenvolvimento de tecnologias, tem-se uma revolução nas formas de estrutura, organização e distribuição do conhecimento acumulado. Contudo isso não garante o acesso ao conhecimento. Para tanto, a

\footnotetext{
2 Disponível em: < http://download.inep.gov.br/educacao basica/enem/downloads/2012/matriz referencia enem.pdf $>$. Acesso em: 27 set. 2016.
} 
capacidade de aprender terá de ser trabalhada. Seria a escola o ambiente propício para se desenvolver a capacidade de se aprender.

Assim, creio que a Matemática deve ultrapassar os limites das disciplinas escolares. Deve ser entendida e apresentada como obra do homem importante e útil tanto quanto a música, a poesia ou a física e a biologia. Claro que a mais inquietante das questões é: como?

Termino com uma frase que é incomodamente atual:

Por mais de dois mil anos, alguma familiaridade com Matemática foi considerada parte indispensável da bagagem intelectual de todas as pessoas cultas. Hoje o lugar tradicional da Matemática na educação encontra-se em sério risco. (COURANT, 1941).

\section{Referências}

BRASIL. Parâmetros curriculares nacionais: introdução aos parâmetros curriculares nacionais. Brasília: MEC/SEF, 1997.

Parâmetros curriculares nacionais: Matemática. Brasília: MEC/ SEF, 1998.

. Parâmetros Curriculares Nacionais (Ensino Médio). Brasília: MEC/SEMTEC, 2000.

PCN + do Ensino Médio, Ciências da Natureza, Matemática e suas Tecnologias. Brasília, DF, 2000.

COURANT, R.; ROBBINS, H. O que é Matemática? Uma abordagem elementar de métodos e conceitos. Rio de Janeiro: Editora Ciência Moderna Ltda., 2000.

MORIN, E. A cabeça bem-feita: repensar a reforma, reformar o pensamento. Rio de Janeiro: Bertrand Brasil, 2001.

SÃO PAULO. Proposta Curricular do Estado de São Paulo: Ensino médio. São Paulo: Secretaria da Educação, 2008. 60 p.

SOUZA, R. F. Áreas do Conhecimento. DataGramaZero. Rio de Janeiro, v. 5, n. 2, 2004. 



\section{A MATEMÁTICA COMO UMA ÁREA DO CONHECIMENTO*}

Nílson José Machado

\section{O ensino médio e a fragmentação disciplinar}

Existe uma aparente unanimidade no diagnóstico do Ensino Médio: a fragmentação disciplinar é excessiva. Em cada disciplina, o discernimento do que é fundamental e do que é acessório parece ter se perdido. Os conteúdos disciplinares são apresentados de modo isolado ou pouco articulado com as outras disciplinas. São, quase sempre, recheados de tecnicidades que parecem dispensáveis e/ou incompreensíveis para os alunos. É crescente o desencontro entre os interesses da Escola, representados pelos currículos e programas, e os interesses dos alunos, imersos em um mundo recheado de apelos tecnológicos. A tarefa do professor como mediador de tal conflito de interesses é absolutamente crucial, mas suas condições de trabalho não deixam espaço para grandes iniciativas criativas. Maior liberdade na escolha de optativas é uma alternativa enganadora. Dependendo do modo como tais disciplinas opcionais forem oferecidas ou ministradas, pouco ou nada mudará. O aumento no número de disciplinas será inevitável e é possível que se pule da panela e se acabe no fogo.

Uma vez que o desinteresse parece apenas um efeito colateral da fragmentação disciplinar, que conduz à perda do sentido do que se estuda, a busca de estratégias de combate à fragmentação é urgente. A mais frequente tem sido o recurso a uma organização das disciplinas por áreas do conhecimento. Nem sempre, no entanto, algumas referências históricas em tal aproximação têm sido consideradas

\section{A Matemática e as áreas do conhecimento}

Talvez a mais cobrada das disciplinas em razão de uma apresentação excessivamente técnica, ou com especificidade exagerada, tenha sido a Matemática. Em decorrência, ao pretender agrupar as disciplinas em áreas, o primeiro impulso tenha sido agregar a Matemática a uma das três áreas criadas: Linguagens, Ciências da Natureza, Ciências Humanas.

A relação com a área de Linguagens parecia natural. Em todas as épocas, em todas as culturas, a Matemática e a Língua Materna constituem dois componentes básicos dos currículos escolares. Tal fato era traduzido, em tempos antigos, pela tríplice caracterização da função da escola, como o lugar em

*DOI - 10.29388/978-85-53111-95-4-0-f.57-62 
que se devia aprender a "ler, escrever e contar", o que significava, sinteticamente, uma dupla "alfabetização", no universo das letras e dos números.

Naturalmente, há muito essa "alfabetização" que se espera da escola ampliou seu raio de ação, incorporando o interesse pelas múltiplas formas de linguagens presentes na sociedade contemporânea, e estendendo-se para os universos das ciências e das tecnologias, particularmente no que se refere às tecnologias informáticas.

Como a Matemática historicamente também sempre esteve associada às Ciências, especialmente às Ciências Naturais, funcionando como uma espécie de fornecedora de instrumentos para a expressão dos resultados científicos, houve também a sugestão - que acabou prevalecendo - de a Matemática ser inserida na área de Ciências da Natureza, configurando, assim, as três áreas do conhecimento, segundo os Parâmetros Curriculares Nacionais (PCN, 1996). O mapeamento do conhecimento a ser apresentado disciplinadamente - e disciplinarmente - na escola conduziu, então, às seguintes grandes áreas:

- Linguagens, incluindo-se as línguas estrangeiras e a Educação Física e Artes, como diferentes formas de expressão;

- Ciências Humanas, incluindo-se História, Geografia, Filosofia e Sociologia;

- Ciências da Natureza e Matemática, uma grande área que incluiu a Física, a Química, a Biologia e a Matemática.

- No que se refere à Matemática, apesar de tal inserção, na prática efetiva não ocorreu tal subsunção à Área de Ciências, permanecendo o território matemático clandestinamente autônomo, com identidade própria

Como já foi dito, existem vínculos e articulações naturais entre a Matemática na Área de Linguagens, uma vez que, acompanhado da Língua Materna, a Matemática compõe o par de sistemas simbólicos fundamentais para a representação da realidade, para a expressão de si e compreensão do outro, para a leitura em sentido amplo, tanto de textos quanto do mundo dos fenômenos. É verdade igualmente que a Matemática mantém relações estreitas com as Ciências da Natureza, em decorrência de sua grande e histórica proximidade com a Física, por exemplo, desde as origens da Ciência moderna, com Galileu, até os trabalhos de Descartes, com seu sonho de expressão de todo conhecimento confiável na linguagem matemática, ou de Newton, com sua imensa competência em traduzir matematicamente fenômenos de múltipla natureza. Mas a Matemática é bem mais do que a linguagem matemática, ou do que um repertório de instrumentos para as Ciências, Naturais ou Humanas. Ela tem um conteúdo próprio de ideias fundamentais que a caracterizam como disciplina, e que, associadas aos desdobramentos atuais da Estatística e das Tecnologias, amplificam em muito o potencial e o repertório instrumentos e formas de expressão para todas as áreas. 
No Estado de São Paulo, as propostas curriculares foram revigoradas e atualizadas de modo significativo em 2008. Nelas, a Matemática sempre foi considerada uma área específica. Tais propostas constituíram um esforço expressivo, e em alguns sentidos pioneiro, na busca de uma aproximação entre os conteúdos escolares e o universo da cultura, especialmente no que tange às contextualizações e à busca de uma instrumentação crítica para o mundo do trabalho. Os documentos oficiais do Estado de São Paulo constituem uma rica herança pedagógica que tem sobrevivido a novidades passageiras. A Matemática, como já foi dito, passou a constituir uma área específica, acompanhada das três já citadas dos PCN.

Em 2009, com a criação do Novo Enem, a Matemática passou a constituir igualmente uma área do conhecimento, tendo se consolidado as quatro áreas já referidas:

- Linguagens, incluindo-se as línguas estrangeiras e a Educação Física e Artes, como diferentes formas de expressão;

- Ciências Humanas, incluindo-se História, Geografia, Filosofia e Sociologia;

- Ciências da Natureza, incluindo-se a Física, a Química e a Biologia;

- Matemática, incluindo-se as interfaces com o tratamento da informação e as tecnologias.

\section{A Matemática como uma área do conhecimento}

Três são as razões principais da opção pela constituição de uma área do conhecimento específica para a Matemática.

Em primeiro lugar, a incorporação da Matemática tanto pela área de Ciências da Natureza quanto pela área de Linguagens pode elidir o fato de que, mesmo tendo as características de uma linguagem e sendo especialmente importante e adequada para a expressão científica, a Matemática apresenta um universo próprio muito rico de ideias e objetos específicos, como os números e as operações, as formas geométricas, as relações entre tais temas, sobretudo as métricas. Tais ideias e objetos são fundamentais para a expressão pessoal, a compreensão de fenômenos, a construção de representações significativas e argumentações consistentes nos mais variados contextos, incluindo-se as chamadas Ciências Humanas.

No caso dos Parâmetros Curriculares Nacionais (PCN), a inclusão da Matemática na área de Ciências da Natureza teve o efeito salutar de diminuir o risco de se ter o conteúdo matemático na Escola Básica como um fim em si mesmo, enfatizando sua condição instrumental. Entretanto, a partir da consolidação da ideia de competências apresentada pelo Exame Nacional do Ensino Médio (ENEM), tal risco teoricamente deixou de existir, explicitando-se com nitidez o que já era apresentado tacitamente em propostas anteriores: todos os 
conteúdos disciplinares, nas diversas áreas, são meios para a formação dos alunos como cidadãos e como pessoas. As disciplinas são imprescindíveis e fundamentais, mas o foco permanente da ação educacional deve situar-se no desenvolvimento das competências pessoais dos alunos.

Uma segunda rąão para a apresentação da Matemática como uma área do conhecimento é o fato de que uma parte importante da especificidade da Matemática resulta esmaecida, quando ela se agrega tanto às linguagens em sentido amplo quanto às ciências da natureza. A Matemática compõe com a Língua Materna um par fundamental, mas um par complementar: é impossível reduzir um dos sistemas simbólicos ao outro. Uma língua que se pretenda aproximar demasiadamente do modo de operar da Matemática resulta empobrecida, o mesmo ocorrendo com um texto matemático que assuma uma ambivalência apropriada apenas à expressão linguística. A multiplicidade de sentidos de cada elemento simbólico é própria da língua corrente e é intencionalmente controlada na expressão matemática. A pretensão da expressão precisa é natural na Matemática, mas pode empobrecer o uso corrente da língua; afinal, a linha reta faz bem ao caráter, mas faz mal ao poeta... Não é que a língua não possa ser precisa: ela o é exemplarmente, como bem o revela o texto poético, em que uma palavra não pode ser substituída nem por um perfeito sinônimo sem desmontar o poema. Naturalmente, existem diferenças fundamentais entre os significados da precisão na Língua e na Matemática, e os alunos devem ser conduzidos a apreciar a beleza presente tanto na exatidão dos cálculos quanto no rigor expressivo do texto poético, por exemplo.

Uma terceira rąão para o tratamento da Matemática como área específica é a possibilidade de tal opção facilitar a incorporação crítica dos inúmeros recursos tecnológicos atualmente existentes para a representação de dados e o tratamento das informações disponíveis, na busca da transformação de informação em conhecimento. De fato, se em vez do Trivium original, constituído pela Lógica, pela Gramática e pela Retórica, decidíssemos propor um novo conjunto de três matérias básicas para a formação da cidadania, mais consentâneo com as características da sociedade contemporânea, certamente pareceria mais justo incluir como componentes do mesmo a Lingua, a Matemática e a Informática. E ainda que os computadores, atualmente, sejam considerados instrumentos absolutamente imprescindíveis para jornalistas e escritores em geral, é no terreno da Matemática que se abrem as mais naturais e promissoras possibilidades de assimilação consciente dos inúmeros recursos que as tecnologias informáticas podem oferecer no terreno da Educação. Ainda que as tais tecnologias estejam presentes e representem um papel importante em todas as áreas do conhecimento, a natureza algorítmica dos computadores aproxima-os especialmente dos conteúdos matemáticos. Se uma máquina, no sentido da Revolução Industrial do século XVIII, era essencialmente um transformador de energia de um tipo em energia de outro tipo, um computador é essencialmente um transformador de mensagens. E o processo de composição e decomposição das mes- 
mas, para viabilizar sua inserção ou sua extração dos computadores, tem muitos elementos comuns com os objetos matemáticos e sua manipulação. Ao falarmos de Matemática e suas tecnologias estamos utilizando a palavra "tecnologia", portanto, em sentido mais próximo do literal do que no caso das extensões metafóricas associadas às Linguagens, às Ciências da Natureza e às Ciências Humanas.

Insistimos, no entanto, no fato de que a apresentação da Matemática como uma área específica não busca uma amplificação de suas supostas peculiaridades, nem sua caracterização como um tema excessivamente especializado ou particularmente relevante. Vivemos uma época em que as atividades interdisciplinares e as abordagens transdisciplinares constituem recursos fundamentais para a construção do significado dos temas estudados, contribuindo de modo decisivo para a criação de centros de interesse nos alunos. Ao respeitar a rica história da disciplina e alçá-la a uma área do conhecimento, busca-se apenas criar as condições para uma exploração mais adequada das possibilidades de a Matemática servir às outras áreas, na ingente tarefa de transformação da informação em conhecimento em sentido amplo, em todas as suas formas de manifestação. 



\section{ELEMENTOS CONSTITUINTES PARA UMA DISCUSSÃO SOBRE A ÁREA DE CONHECIMENTO ENSINO DE MATEMÁTICA NA FORMAÇÃO DE PROFESSORES*}

Ana Lúcia Manrique

Foi colocada a seguinte questão para nossa reflexão: Quais são as implicações no ensino ao se reconhecer a Matemática como área de conhecimento, ultrapassando os limites de uma disciplina escolar?

$\mathrm{O}$ aspecto que mais chamou nossa atenção foi o fato de considerar que a reflexão deveria ultrapassar os limites de uma disciplina escolar, por entendermos que a Matemática é reconhecida como uma área de conhecimento em diversos documentos. Por exemplo, para a Coordenação de Aperfeiçoamento de Pessoal de Nível Superior (Capes) ${ }^{1}$, uma área de conhecimento é entendida como um conjunto de conhecimentos construídos coletivamente, que apresentam relacionamentos intrínsecos. Além disso, esses conhecimentos estão reunidos devido a sua natureza e com finalidades de ensino, pesquisa e aplicações práticas. Na Capes, a área de conhecimento Matemática é dividida em quatro subáreas: Álgebra, Análise, Geometria e Topologia e Matemática Aplicada, abrangendo alguns conteúdos específicos.

Os Parâmetros Curriculares Nacionais - PCN também consideram a Matemática como uma área de conhecimento e agregam os conhecimentos relativos a essa área em quatro blocos de conteúdos: Números e Operações, Espaço e Forma, Grandezas e Medidas e Tratamento da Informação.

Dessa forma, podemos perceber que existe consenso em relação a considerar a Matemática como uma área de conhecimento, mas não em relação a sua organização. E o desafio que se coloca, quando se pensa no ensino de Matemática para a educação básica, refere-se, mais que determinar quais conteúdos devem ser selecionados e trabalhados, a quais procedimentos, competências e atitudes devem ser priorizados para a formação do cidadão brasileiro. E é um desafio por entendermos que a apropriação da Matemática também é um direito de todo estudante da educação básica e que aprender Matemática favorece um modo de pensar próprio.

Desde a década de 1960, existem pesquisadores que estudam e pesquisam o ensino e a aprendizagem da Matemática e de outras Ciências nos diferentes níveis de ensino.

\footnotetext{
${ }^{*}$ DOI - 10.29388/978-85-53111-95-4-0-f.63-68

${ }^{1}<$ www.capes.gov.br $>$
} 
Nardi (2015, p. 1) afirma que:

As características inter ou multidisciplinares que esse tipo de pesquisa demanda fizeram entender, logo cedo, que conhecer profundamente apenas os conteúdos das disciplinas de Ciências e Matemática não bastava para se avançar no estudo das particularidades que os processos de ensino e de aprendizagem das Ciências demandam.

Decorrente dos conhecimentos acumulados pelas pesquisas e estudos realizados nessas temáticas, que foram construídos coletivamente, em 2008, a Capes reconheceu a área de Ensino como uma área de conhecimento.

Nesse sentido, considerar o Ensino como área de conhecimento significa, em nosso entendimento, que conhecimentos da área de conhecimento Matemática necessitam se agregar a outros conhecimentos próprios do professor de Matemática (que envolvem também conhecimentos sobre os processos de aprendizagem dos estudantes), para serem investigados, ensinados e aplicados em situações práticas na Educação Básica. Entre esses conhecimentos próprios dos professores podemos apontar os conhecimentos didáticos do conteúdo matemático, que compreendem as analogias e os exemplos que o professor pode utilizar para que o estudante compreenda o conteúdo tratado, e os conhecimentos curriculares dos conteúdos matemáticos, que englobam os materiais e recursos curriculares que o professor pode escolher para abordar o conteúdo (SHULMAN, 1986).

Podemos ainda pensar que considerar o Ensino como área de conhecimento na formação do professor de Matemática significa, também em nosso entendimento, que é necessário agregar estudos sobre competências matemáticas (NISS, 2003) para que os conhecimentos matemáticos possam ter as finalidades de investigação e aplicação prática. Ter um estudante com competência matemática implica, então, que ele tem "a capacidade de compreender, julgar, fazer e usar a matemática em uma variedade de contextos intra e extra-matemáticos e em situações em que a matemática desempenha ou poderia desempenhar um papel relevante" (JUNQUEIRA; MANRIQUE, 2013, p. 2).

Ao apontarmos que competências matemáticas e conhecimentos próprios dos professores de matemática devem fazer parte das discussões sobre a área de conhecimento Ensino de Matemática, queremos dizer que se o estudante tem apenas conhecimentos matemáticos da área de conhecimento Matemática, não podemos considerar que ele tenha competências matemáticas, nem que ele consiga realizar algum tipo de investigação ou aplicação prática na educação básica, utilizando-se de conteúdos matemáticos.

Niss (2003) apresenta quatro competências matemáticas para fazer e responder perguntas na Matemática e com a Matemática, são elas: pensar matematicamente; fazer e resolver problemas matemáticos; modelar e raciocinar matematicamente. Essas competências matemáticas estão listadas no Quadro 1. 
Quadro 1 - Competências para fazer e responder perguntas em e com a Matemática $1^{\circ} \mathrm{GRUPO}$

\section{COMPETÊNCIAS PARA FAZER E RESPONDER PERGUNTAS EM E COM} A MATEMÁTICA

\section{Pensar matematicamente}

- Fazer perguntas que são características da Matemática e conhecer os tipos de respostas que a Matemática pode oferecer;

- Compreender e lidar com o alcance e as limitações de um determinado conceito;

- Alargar o âmbito de um conceito abstraindo algumas de suas propriedades e generalizando resultados para outros objetos;

- Distinguir entre diferentes tipos de afirmações matemáticas, declarações com quantificadores, suposições, definições, teoremas, conjecturas, casos).

\section{Fazer e resolver problemas matemáticos}

- Identificar, levantar e especificar diferentes tipos de problemas matemáticos (puros ou aplicados, abertos ou fechados);

- Resolver diferentes tipos de problemas matemáticos, sejam colocados por outros ou por si mesmo, e, se for o caso, de maneiras diferentes.

\section{Modelar matematicamente}

- Analisar fundamentos e propriedades de modelos existentes, incluindo a avaliação de seu alcance e validade;

- Decodificar modelos existentes, ou seja, traduzir e interpretar elementos do modelo em termos da "realidade" modelada;

- Realizar a modelagem de forma ativa em um determinado contexto, realizando: a estruturação do campo, a modelação, o trabalho com e no modelo, a validação do modelo - interna e externamente, a análise e a crítica do modelo e o controle de todo o processo de modelagem.

\section{Raciocinar matematicamente}

- Acompanhar e avaliar cadeias de argumentos, defendidas por outros;

- Saber o que é uma prova matemática (ou não), e como ela difere de outros tipos do raciocínio matemático;

- Descobrir ideias básicas de uma determinada linha de argumentação (especialmente uma prova), incluindo distinguir principais linhas de ideias das técnicas;

- Elaborar argumentos matemáticos formal e informalmente, e transformar argumentos heurísticos provar afirmações.

Fonte: Niss (2003).

E um segundo grupo de competências matemáticas propostas por Niss (2003) abrange as competências para lidar e gerenciar a linguagem matemática, bem como usar suas ferramentas, são elas: representar entidades matemáticas; manipular símbolos matemáticos e formalismos; comunicar em, com e sobre a matemática e fazer uso de aparelhos e ferramentas. Essas competências matemáticas estão listadas no Quadro 2. 
Quadro 2 - Competências para lidar e gerenciar a linguagem matemática e suas ferramentas $2^{\circ}$ GRUPO

COMPETÊNCIA PARA LIDAR E GERENCIAR A LINGUAGEM MATEMÁTICA E SUAS FERRAMENTAS

\section{Representar as entidades matemáticas}

- Entender e utilizar, no sentido de decodificar, interpretar e distinguir entre diferentes tipos de representações de objetos matemáticos, fenômenos e situações;

- Entender e utilizar relações entre diferentes representações de uma mesma entidade, incluindo conhecer seus pontos fortes e limitações;

- Escolher e alternar entre representações.

\section{Manipular símbolos matemáticos e formalismos}

- Decodificar e interpretar linguagem matemática simbólica e formal, e compreender suas relações com a linguagem natural;

- Compreender a natureza e as regras de sistemas formais da matemática (sintaxe e semântica);

- Traduzir da linguagem natural para a linguagem formal/simbólica;

- Manipular declarações e expressões que contenham símbolos e fórmulas.

7. Comunicar em, com e sobre a matemática

- Compreender outros escritos, como "textos" visuais ou orais, em uma variedade de registros linguísticos, sobre questões que contenham algum conteúdo matemático;

- Expressar-se, em diferentes níveis de precisão teórica e técnica, na forma oral, visual ou escrita, sobre tais assuntos.

\section{Fazer uso de aparelhos e ferramentas}

- Conhecer a existência e as propriedades de várias ferramentas e apoios para a atividade matemática, bem como seu alcance e limitações;

- Ser capaz de utilizar reflexivamente essas ferramentas e apoios.

Fonte: Niss (2003).

Com esse conjunto de competências matemáticas agregadas aos conhecimentos matemáticos entendemos que o estudante da educação básica possa fazer algum tipo de investigação e de aplicação prática com os conhecimentos matemáticos.

Mais ainda, salientamos que essa discussão sobre os conhecimentos da área de conhecimento Ensino na formação do professor de Matemática necessita abranger também elementos não cognitivos, tais como: reconhecer, expressar e gerir emoções; construir relações saudáveis; estabelecer objetivos positivos; dar resposta a necessidades pessoais e sociais; e tomar decisões de maneira responsável (COSTA; FARIA, 2013). Pois, as competências matemáticas e os conhecimentos matemáticos podem ser mais facilmente adquiridos quando o estudante se envolve nos diferentes tipos de atividades propostas pelo professor e sintam confiança para realizar as atividades com autonomia. 


\section{Referências}

BRASIL. Parâmetros Curriculares Nacionais: Matemática. Brasília: MEC/ SEF, 1997.

COSTA, A.; FARIA, L. Aprendizagem social e emocional: Reflexões sobre a teoria e a prática na escola portuguesa. Análise Psicológica. v. 31, n. 4, p. 407424, 2013.

JUNQUEIRA, S. M. S.; MANRIQUE, A. L. O desenvolvimento de competências matemáticas em aulas da disciplina de Cálculo 1. In: CONGRESSO IBEROAMERICANO DE EDUCAÇÃO MATEMÁTICA, 7., 2013, Montevideo. Anais... Montevideo: CIBEM, 2013. p. 1-8.

NARDI, R. A pesquisa em ensino de Ciências e Matemática no Brasil. Ciênc. educ. (Bauru), Bauru, v. 21, n. 2, p. 1-5, jun. 2015.

NISS, M. Mathematical competencies and the learning of mathematics: The Danish KOM project. In: GAGATSIS, A.; PAPASTAVRIDIS, S. (Ed.). 3rd Mediterranean Conference on Mathematical Education. Athens: Hellenic Mathematical Society, 2003. p. 1-12.

SHULMAN, L. S. Those who understand: knowledge growth in teaching. Educational Researcher. v. 15, n. 2, p. 4-14, 1986. 



\section{ESPECIFICIDADES DO CONHECIMENTO DO PROFESSOR COMO VEÍCULO QUE PERMITE TRANSCENDER AS FRONTEIRAS DA DISCIPLINA ESCOLAR ATÉ A ÁREA DE CONHECIMENTO*}

Miguel Ribeiro

\section{Palavras iniciais}

Quando pensamos em Matemática e, em particular, no conhecimento matemático, duas dimensões são, normalmente, consideradas: a Matemática enquanto Ciência (desenvolvida por matemáticos) e a matemática enquanto disciplina escolar - considerada também como matemática escolar (utilizada pelos professores e assumida, inclusivamente pelos documentos oficiais, frequentemente, de forma compartimentada). Estas duas dimensões associam-se, tradicionalmente, a diferentes níveis (tipos e formas) de saber matemático, o que contribui, também, para que se assumam como dimensões dissociadas e, frequentemente, opostas. Este assumir das duas faces de uma moeda sustenta-se, também, no considerar uma desconexão entre o saber e fazer matemático e o saber escolar (mobilizado e promovido em contexto escolar). A assunção desta desconexão sustenta uma visão da matemática como produto acabado, identificando-se os conteúdos com os conceitos, enunciados como objetivos de carácter terminal e funcional, e colocando a ênfase nos objetivos procedimentais locais - associados a cada um dos conteúdos específicos (RIBEIRO; CARRILLO, 2011a). A aproximação entre estes "dois mundos" é considerada a pedra basilar que ditará a transformação da Matemática enquanto disciplina para Área de Conhecimento.

Por forma a articular o saber e fazer matemático e o saber escolar será necessário que o processo de ensino e aprendizagem possa ocorrer perseguindo objetivos a médio e longo prazo (complementarmente aos imediatos), buscando que os alunos entendam o que fazem e porque o fazem a cada momento. Porém, para tornar realidade essa conexão, é essencial quebrar as amarras que nos restringem e considerar, em particular, a matemática e o conhecimento matemático como algo que transcende as fronteiras do que, tradicionalmente, se ensina e "aprende" na escola e, essencialmente, o foco, natureza e objetivos matemáticos desses processos. De entre uma diversidade de fatores que podem ser enunciados por forma a justificar a possibilidade da transcendência da Matemática de disciplina escolar a Área de Conhecimento (alguns deles são foco de discussão nos outros textos), aqui considera-se um foco no professor e

${ }^{*}$ DOI - 10.29388/978-85-53111-95-4-0-f.69-74 
no seu conhecimento - pela sua centralidade nos processos envolvidos que possibilitarão essa transcendência. Nesse sentido, para a efetivação dessa transcendência (que se assume possível, mas não imediata), é essencial que o professor detenha um conhecimento matemático especializado no sentido de Carrillo (CARRILHO, et al., 2013) que lhe possibilite, entre outros, usar (a matemática tem) e explorar (a matemática é) a linguagem matemática nas suas múltiplas formas (e.g., numérica, algébrica, pictórica); considerar simultaneamente uma visão local e global da matemática (e.g., conexões temporais) e assumi-la tanto como ponto de partida e de chegada para um mais pleno entendimento do mundo que nos rodeia (e.g., conexões intra e extraconceptuais e conexões extramatemática) (MONTES, et al., 2016).

\section{De disciplina escolar a área de conhecimento: as especificidades do conhecimento do professor que ensina(rá) Matemática}

Pensando na Matemática como Ciência, esta foi/é "transformada" em disciplina escolar sempre e quando a essa transformação se encontram associadas um conjunto de compartimentações que restringem a profundidade e amplitude das discussões bem como as formas como as diferentes dimensões da Ciência são, ou não, consideradas. Nesse sentido, os pressupostos que permitem considerar a Matemática como Área de Conhecimento levam ao enriquecimento e expansão da visão da Matemática como disciplina escolar. Esta expansão associa-se, e sustenta-se, na possibilidade de criação de uma ampla rede conceptual que suporta um pensar e fazer matemático, bem como de um panorama de conexões que permitam entender e atribuir significados a conhecimentos envolvidos em contextos matemáticos e não matemáticos de forma conjunta e integrada (e.g., conexões entre a Matemática e a Economia, Física, Química, Artes).

De entre os pressupostos que se podem enunciar como sustentadores dessa transcendência de fronteiras e de descompartimentalização - considerados elementos essenciais para tornar realidade uma sociedade matematicamente crítica e detentora de sustentada numeracia e literacia - o elemento nuclear é o professor e o seu conhecimento. Assim, dado que o conhecimento do professor é o fator que maior impacto possui nos resultados (e aprendizagens) dos alunos (NYE; KONSTANTOPOULOS; HEDGES, 2004), e considerando a natureza especializada desse conhecimento, assume-se a perspectiva de que para que a Matemática seja efetivamente assumida como uma Área de Conhecimento, e não apenas "mais uma" disciplina, o professor (e obviamente o formador de professores), o seu conhecimento especializado e forma(s) de considerar a matemática e seu ensino assume a centralidade do processo.

Há já mais de 30 anos que a problemática do conhecimento do professor tem vindo a ser foco de atenção. Desde as ideias discutidas por Shulman (1986) diversas conceptualizações do conhecimento do professor têm vindo a 
emergir, concretizando essas ideias (no âmbito da educação em geral) para o contexto do ensino da matemática. Ainda assim, algumas dessas conceptualizações continuam a sustentar os seus argumentos numa visão compartimentada da Matemática (apenas apresentando diferentes perspectivas para essa compartimentação), considerando-a como "mais uma" disciplina escolar.

A perspectiva aqui assumida é algo distinta já que se assume explicitamente a especialização do conhecimento do professor que ensina/ensinará matemática, considerando essa especialização tanto no que concerne ao conhecimento do conteúdo (matemático) quanto ao conhecimento pedagógico do conteúdo (BALL; THAMES; PHELPS, 2008; CARRILLO, et al., 2013; RIBEIRO, 2013; RIBEIRO; MELLONE; JAKOBSEN, 2016). Nesse sentido, à formação de professores que ensinam matemática, cumprirá desenvolver um conjunto de saberes docentesque os capacite a promover discussões matematicamente significativas com os seus alunos, transcendendo as fronteiras estabelecidas para a disciplina escolar (e.g., pelos documentos oficiais, pelos livros didáticos). Esse conhecimento deverá permitir atribuir significado, explorar e ampliar a diversidade de formas e percursos de obter e registar as respostas para as questões e problemas que colocam, não assumindo apenas objetivos finais (resposta final) e imediatos, mas considerando também a importância do percurso efetuado (RIBEIRO, 2013) nas aprendizagens e para essas aprendizagens dos alunos.

Assim, a conceptualização do Mathematics Teachers' Specialzed Knowledge (CARRILLO, et al., 2013), ao assumir como ponto de partida a especialidade do conhecimento matemático do professor que ensina/ensinará matemática, sustenta-se na não compartimentalização do conhecimento matemático - uma vez que se assume que o professor que ensina matemática, pretenderá que os seus alunos entendam o que fazem e porque o fazem, a cada momento - cumpre um saber que inclua, entre outros, um conhecimento de diferentes conexões, tanto em tipo, como em forma (MONTES, et al., 2016). Nesse sentido, e também por limitação de espaço, dado que o conhecimento pedagógico do conteúdo é suportado pelo conhecimento do conteúdo, (KRAUSS, et al., 2008), o argumento aqui utilizado sustenta-se essencialmente nos aspetos das especificações do conhecimento matemático que potenciarão o assumir a Matemática como Área de Conhecimento ${ }^{1}$.

Assim, ao professor (que pretende que os seus alunos entendam o que fazem e porque o fazem a cada momento) cumprirá um conhecimento mais amplo que o associado à matemática como disciplina escolar. Cumpre, portanto, um conhecimento que vá mais além do que os seus alunos aprendem, bem como um conhecimento relativo aos fundamentos matemáticos, procedimentos "tradicionais" e alternativos ou às distintas formas de representação dos diferentes tópicos. Ao professor cumprirá, também um conhecimento associa-

\footnotetext{
${ }^{1}$ Note-se que diversos argumentos podem ser também, necessariamente, enunciados associados às especificidades do conhecimento didático-pedagógico do professor que ensina matemática de modo a que a Matemática passe de disciplina escolar a Área de Conhecimento.
} 
do aos conceitos permitindo relacioná-los com contextos reais (conexões, por exemplo, com a Biologia, a Arte, a Química) ou com o próprio conteúdo matemático (conexões dentro da própria Matemática - no mesmo tema ou com outros temas, tanto na mesma etapa educativa como em etapas distintas) recorrendo a exemplos que contribuam com aspetos epistemológicos que permitam ao professor compreender diferentes significados que se podem atribuir ao conteúdo assim como a variedade de contextos em que se pode situar cada um dos conteúdos.

Complementarmente, ao professor que ensina(rá) matemática, contemplando a Matemática como Área de Conhecimento, cumprirá um conhecimento associado à estrutura da matemática, incluindo um conhecimento matemático de cada um dos temas assumindo uma perspectiva da sua integração e relação com estruturas mais amplas e com maior capacidade de relação com outros temas e conceitos - conhecimento global e não apenas local. Inclui-se aqui um conhecimento das relações/conexões tanto com conceitos mais avançados como com conceitos mais elementares que permitam que o professor possa trabalhar a matemática elementar de um ponto de vista superior e vice-versa (KLEIN, 1932; MONTES, et al., 2016).

Ainda incluído no conhecimento do conteúdo, considera-se um conhecimento matemático associado às formas de fazer matemática. De entre essas formas de fazer matemática podem ser referidas, as diferentes formas de demonstrar, os critérios a estabelecer para que uma generalização seja válida, o significado de definição, axioma ou teorema como elementos constituintes da matemática, ou o conhecimento da sintaxe matemática. Incluem-se aqui também conhecimentos de diferentes estratégias de resolução de problemas ou de modelagem, as quais incluem um saber associado à estrutura lógica em que a resolução se sustenta.

\section{Alguns comentários finais}

A amplificação da visão da Matemática que permita transcender as fronteiras da disciplina apenas terá efeito (e sentido) caso o desenvolvimento do saber dos alunos seja encarado de forma mais ampla do que associado apenas a um saber fazer - conhecimento matemático como aplicação. Por forma a facilitar essa ampliação, como constituinte do conhecimento especializado do professor inclui-se também um saber associado ao que corresponde fazer Matemática enquanto Ciência (e.g., etapas do processo de fazer matemática, tipos, formas e processos de prova), criando um espaço que permite aproximar as duas faces da mesma moeda, até que se complementem. Assim, a necessidade de perseguir objetivos a médio e longo prazo, sustenta também a necessidade de que a formação de professores (inicial e continuada) que ensinam(rão) matemática (desde a Educação Infantil) tenha como foco o desenvolvimento desse conhecimento especializado. 
Assim, considerar a Matemática como Área de Conhecimento que, em si, expande as fronteiras da disciplina escolar implica a exploração e discussão (e desenvolvimento de um conhecimento sobre) de situações matematicamente potentes e didaticamente significativas, permitindo relacionar tanto os conteúdos, a estrutura da própria matemática e o fazer matemático bem como com os diversos aspetos do conhecimento didático-pedagógico do conteúdo.

\section{Referências}

BALL, D.; THAMES, M. H.; PHELPS, G. Content Knowledge for Teaching: What makes it special? Journal of Teacher Education, v. 59, p. 389-407, 2008.

BRASIL. Parâmetros curriculares nacionais: Matemática. Ensino de quinta à oitava série. Brasília: MEC/SEF, 1998.

CARRILLO, J. et al. Determining Specialized Knowledge for Mathematics Teaching. In: PROCEEDINGS OF CERME, 8., 2013, Antalya. Anais... Antalya: METU, 2013. p. 2985-2994.

KLEIN, F. Elementary mathematics from an advanced standpoint. Volume 1: Arithmetic, algebra, analysis. Translated by Earle Raymond Hedrick and Charles Albert Noble. 3. ed. New York: Macmillan, 1932. (Original work published 1924).

KRAUSS, S. et al. Pedagogical Content Knowledge and Content Knowledge of Secondary Mathematics Teachers. Journal of Educational Psychology, v. 100, n. 3, p. 716-725, 2008.

MONTES, M. et al. Understanding mathematics from a higher standpoint as a teacher: an unpacked example. In: CSÍKOS, C., RAUSCH, A., SZITÁNYI, J. (Ed.). Proceedings of the $\mathbf{4 0}^{\text {th }}$ Conference of the International Group for the Psychology of Mathematics Education. Szeged: PME., 2016. v. 3, p. 315-322.

NYE, B.; KONSTANTOPOULOS, S.; HEDGES, L. V. How large are teacher effects? Educational Evaluation and Policy Analysis, v. 3, n. 26, p. 237-257, 2004.

RIBEIRO, C. M. Del cero hasta más allá del infinito - algunas perspectivas desde el comienzo de la tesis doctoral hasta el futuro "también" a largo plazo. In: ALCARAZ, A. B. et al. (Ed.) Investigación en Educación Matemática XVII. Bilbao: Universidad del País Basco, SEIEM. 2013. p. 71-85. ISBN 97884-9860-843-4.

RIBEIRO, C. M.; CARRILLO, J. Discussing a teacher MKT and its role on teacher practice when exploring Data analysis. In: UBUZ, B. (Ed.). Proceedings 
of the $35^{\text {th }}$ Conference of the International Group for the Psychology of Mathematics Education. Ankara: PME., 2011a. v. 4, p. 41-48. ISBN 978-975429-262-6.

. The role of beliefs and knowledge in practice. In: ROESKEN, B.;

CASPER, M. (Ed.). Current state of research on mathematical beliefs

XVII: Proceedings of the MAVI-17 Conference. Bochum: Professional School of Education, Ruhr-Universität Bochum, 2011b. p. 192-201.

RIBEIRO, C. M.; MELLONE, M.; JAKOBSEN, A. Interpreting students' non standard reasoning: insights for mathematics teacher education practices. For the Learning of Mathematics, v. 36, n. 2, p. 8-13, 2016.

SHULMAN, L. Those who understand: Knowledge growth in teaching. Educational Researcher, v. 15, n. 2, p. 4-14, 1986. 


\section{PARTE II \\ ELEMENTOS EM DEBATE PARA ANÁLISE}





\section{DESAFIOS PARA TRATAR O ENSINO DA MATEMÁTICA COMO ÁREA DE CONHECIMENTO NA EDUCAÇÃO BÁSICA*}

\section{Acolhimento: Prof. Menezes}

Bom meus amigos, espero que todos vocês se sintam extremamente bem-vindos para essa nossa manhã de trabalho. Hoje contamos com a presença de meia dúzia de autores, especialistas da área da Educação Matemática, que se colocaram à disposição para debater a Matemática como Área de Conhecimento na Educação Básica. Todos nos mandaram previamente seus textos, que foram previamente distribuídos a todos os presentes neste encontro. Eu li todos com muito prazer. Nenhum deles se parece com o outro. Nenhum se superpõe e nem fala das mesmas coisas. Essa diversidade é belíssima. Esta é a graça da profissão intelectual. Temos pensares autônomos, focos diferentes e isto é muito bom.

Esse encontro é importante porque quando se fala em área de conhecimento, parece que está tudo dado. Parece que tudo mundo sabe do que se trata. E isso não é verdade, nem no âmbito acadêmico nem no âmbito educacional.

No âmbito acadêmico, há certo consenso de que história e geografia sejam partes da área de humanas. Mas a ideia de que filosofia também a integra, já não tem tanto consenso assim. Isso porque há aqueles que não compreendem a Filosofia como ciência, reservam a ela um papel especial, diferenciado. Aliás, o mesmo acontece com a matemática. Destaco isso para evidenciar que o pensar em Áreas de Conhecimento pode dar a impressão que está tudo certo, mas, de fato, não está.

No âmbito educacional, essa discussão já de data de mais ou menos 20 anos. Pelo menos dois de nós aqui presentes fizemos parte dessa proposta àquela época. $\mathrm{E}$ tenhamos a tranquilidade em salientar: a proposta não colou na escola. A escola manteve seu funcionamento por componentes, pelas disciplinas, e mal se conversam dentro das próprias áreas.

Mas a proposição de que o trabalho escolar se desenvolva de forma articulada dentro dessas áreas ainda está presente. Por isso, é muito importante o debate de hoje para que possamos pensar nas implicações de "escutamos" a Matemática como área na perspectiva da formação escolar, da organização escolar no âmbito da Educação Básica.

Matemática tem, não só, desenvoltura, porte, tamanho e interlocução com as demais componentes curriculares para se apresentar como área, no entanto não está nada claro relativamente a isto. Então nós não estamos discutin-

*DOI - 10.29388/978-85-53111-95-4-0-f.77-98 
do alguma coisa que está muito bem estabelecida, mas é alguma coisa que precisa estar bem estabelecida para se conduzir com eficácia e com coerência a formação escolar.

Então esse encontro trata de um tema relevante, mas que ao mesmo tempo é obscuro. Nada melhor do que algo assim para ser discutido.

Portanto, não me surpreende que os seis trabalhos, que eu pude ter o prazer de ler antecipadamente, tratem a temática de forma tão diversa. Em cada um deles a temática proposta foi vista por um prisma diferente, numa perspectiva diferente. E é essa diversidade, saliento mais uma vez, que traz a riqueza dessa nossa discussão.

Obviamente tenho meus pontos de vista, mas vamos reservar a expressão deles mais tarde depois de ouvi-los.

Eu não quero tomar mais tempo. Então, comecemos. Peço ao Prof. Adilson, que organizou esse evento, dê início aos trabalhos.

\section{Início dos Trabalhos: Prof. Adilson}

Obrigado, Menezes. Começo agradecendo a presença de todos, em especial a toda a equipe que conseguiu tornar real este evento e aos professores que se colocaram à disposição para a escrita e debate sobre essa temática.

Neste pouco tempo que pretendo usar para iniciar os trabalhos, farei uma brevíssima apresentação de todos os presentes e em seguida justificar e explicitar o objetivo desta dinâmica e como ela se desenvolverá.

\section{Primeiro, qual foi o start dessa discussão?}

Desde que assumi o cargo na coordenação da área de matemática, venho apresentando a proposta de formação da Faculdade SESI-SP de Educação em diferentes espaços, da mesma forma que tenho observado sua apresentação feita por colegas de trabalho.

Nessa apresentação, é evidenciada uma de suas características distintivas: sua proposta de formação por áreas de conhecimento. Nesse momento, geralmente cada uma das quatro áreas que a faculdade tem curso de licenciatura é apresentada como sendo um conjunto de componentes curriculares. A área de Linguagens como sendo composta por Língua Portuguesa, Inglês e Artes. A área de Ciências da Natureza composta por Física, Biologia, Química e Ciências. A área de Ciências Humanas composta pelas componentes de História, Geografia, Filosofia e Sociologia. E quando é apresentada a área de Matemática, a expressão mais recorrente tem sido algo próximo de: "E Matemática, que por si só é uma área de conhecimento".

E essa expressão vem desde então me inquietado.

Apesar da Matemática ter se naturalizado como uma área de conhecimento, sendo anunciada desta forma há décadas em diversos documentos ofici- 
ais, em propostas curriculares e em exames nacionais, tenho me perguntado: "será que ela está sozinha por que foi o que restou?" ou "será que suas características a torna realmente uma área específica?". Dessas dúvidas decorreram outras: "O que difere na Educação Básica, a matemática ser tratada como uma disciplina escolar ou como uma área de conhecimento?", "Será que se a matemática em seu ensino se tornar significativa para os alunos, não estaria sendo tratada como uma área de conhecimento?".

E minha inquietação aumentou quando escutei de um colega "que his tória que é esta? Esta discussão sobre área de conhecimento não te pertence. Ela é inerente às outras áreas" e quando fui questionado por um aluno "Como devo ser para ser um professor de matemática tratada como uma área de conhecimento?"

Como essas questões têm orientado algumas das reflexões em nossos cursos de especialização no ensino da Matemática daqui da Faculdade, optamos por promover esse encontro como sendo uma de nossas atividades no módulo que trata sobre a pesquisa em Educação Matemática.

Portanto, dado o exposto, essa dinâmica terá por objetivo identificar os elementos que caracterizariam a matemática tratada como área de conhecimento e as implicações dessa proposta na Educação Básica.

Por tudo isso, espero que todos os presentes percebam o porquê agradeço muito pela presença de todos vocês que aceitaram esse desafio em produzir um texto sobre o assunto. Vocês que são pessoas, professores e pesquisadores que admiro muito.

Acredito que quando nos propomos a falar sobre áreas de conhecimento, duas dimensões precisam ser analisadas.

Numa perspectiva da organização escolar, com professores trabalhando por área de conhecimento, necessariamente tem sua carga horária de trabalho aumentada em uma mesma escola possibilitando sua maior fixação em uma mesma escola. Numa perspectiva pedagógica, o trabalhar por área de conhecimento requer olhar diferenciado sobre o currículo escolar na busca da quebra da compartimentalização hoje existente e que força uma outra lógica. A Educação do Campo já nos mostra experiências nesta proposta de se trabalhar, na área de formação de professores, com áreas de conhecimento.

Será neste contexto que cada um dos presentes nesta mesa apresentará suas colaborações nesta dinâmica que hoje propomos para tratar a temática.

Nesse trabalho, uma adaptação da dinâmica conhecida Grupo de Observação e Verbalização, GOGV, teremos neste grupo de verbalização, um tempo de quinze minutos para que cada um responda às questões elaboradas pelos nossos alunos da Pós-Graduação e que foram enviadas previamente.

Em seguida, cada um tempo de 10 minutos para fazer uma abordagem final. 


\title{
Apresentação do Prof. Miguel Ribeiro:
}

\author{
Prof. Adilson Dalben:
}

Vamos começar pelo professor Miguel Ribeiro, que recebeu as seguintes questões de nossos alunos:

1) Quais são os conhecimentos especializados do professor de Matemática necessários para que o trabalho escolar transcenda as fronteiras da disciplina escolar? Como isso pode acontecer?

2) A necessidade de perseguir objetivos a médio e longo prazo, sustenta também a necessidade de que a formação de professores (inicial e continuada) que ensinam(rão) matemática (desde a Educação Infantil) tenha como foco o desenvolvimento desse conhecimento especializado. Como pode acontecer a formação ou "re-formação" dos profissionais da educação?

Prof. Miguel Ribeiro:

Vou tentar apresentar algumas reflexões que surgiram tanto de ter-me obrigado a escrever o texto, que confesso que foi difícil, foi algo que não faz propriamente parte do trabalho que eu desenvolvo e que me obrigou a pensar de forma diferente também no trabalho que faço. Vou tentar falar um pouco sobre isto e também um pouco sobre tentando responder as duas questões que vocês me colocaram.

Quando pensamos a matemática como área de conhecimento como disciplina escolar, para mim uma das grandes diferenças está alinhada com o que o Adilson também referiu, tem a ver tanto com reorganização escolar - e isto implico a diferentes tipos de trabalho do professor-, como com a descompartimentalização da escola e das próprias disciplinas escolares. Se nos considerarmos a disciplina escolar como algo que começa às $8 \mathrm{~h}$ e acaba às $9 \mathrm{~h}$, a seguinte começa às 9:10 e acaba às 10:10h acaba por não ter a tal descompartimentalização, acaba por estar compartimentalizado e a escola está organizada com os saberes separados e não comunicativos. Ou seja, física e química usam a matemática, mas usam como instrumento, e o professor de matemática até pode apresentar alguns exemplos de química, mas não faz as conexões devidas; apresenta a química como um exemplo e não necessariamente como um contexto.

Fazer estas conexões, este tipo de discussão para mim é um aspecto essencial que vai permitir encarar a matemática ou fazer com que a matemática seja efetivamente uma área de conhecimento que vai permitir descompartimentalizar, que vai permitir a reorganização do saber escolar que não seja um saber situado só em "estudei para a prova", "aprovei na prova", mas que seja um saber que tenha utilidade no dia a dia. Não é um saber apenas prático no imedia- 
to, mas um saber de resolver problemas, interpretar informação de qualquer jornal, meio de comunicação, um saber matemático critico que permita criticar as vivências diárias. E como é que isto pode acontecer, que era a primeira ques tão que me colocavam: Quais os conhecimentos especializados do professor de modo em que a matemática posso transcender as fronteiras da disciplina escolar transformando-se nesta área do conhecimento que vai permitir fazer muitas outras cosias mas algumas daquelas que eu referi antes.

Eu neste momento não posso dizer que os conhecimentos especializados são estes, porque se falarmos de geometria, existe um conjunto de conhecimento especializado; se falarmos de números, existe um outro conjunto de conhecimentos especializados. Dentro da Geometria, se falarmos sobre polígonos, temos um determinado conjunto. Se falarmos de transformação geométrica, temos outro conjunto de conhecimento especializado. Mas é importante chamar atenção que quando eu falo do conhecimento especializado do professor eu falo como a origem para promover esta transcendência de fronteiras entre a disciplina escolar e a área de conhecimento. Esta especialização do conhecimento do professor refere-se tanto ao conhecimento matemático quanto ao conhecimento didático ou pedagógico.

Não é apenas normalmente.... Quando se fala do conhecimento específico do professor pensa-se, em muitas instâncias, o que o professor tem que saber para ensinar, ou seja, o componente pedagógico. $\mathrm{Na}$ abordagem que nós temos vindo a fazer, esta especialidade refere-se também - e essencialmente no primeiro passo-, ao conhecimento do conteúdo matemático que nós temos que ter para depois, então, podemos pensar como vamos abordar determinado conteúdo.

A outra questão referia-se como pode acontecer a formação ou reformação das profissionais da educação, de modo a que consiga efetivamente perseguir objetivos a médio e a longo prazo - não apenas objetivos imediatos-, mas que tipo de formação, de atividades de formação inicial ou continuada que podem ou devem ocorrer de modo que o desenvolvimento deste conhecimento especializado possa ser promovido levando a transcender as fronteiras da disciplina escolar.

Em primeiro lugar, que eu considero essencial, e que uma análise dos currículos brasileiros, da formação dos professores brasileiros, mexicanos, chilenos, portugueses, noruegueses e italianos mostra que a maioria das licenciaturas o que pretende é formar bons alunos do ensino fundamental II e ensino médio. Quando digo bons alunos é futuros professores na perspectiva de saberem responder as questões que são colocadas aos alunos. Isto é a conclusão dos estudos que nós temos estado a realizar, a relacionar com a avaliação das licenciaturas.

O que é que se pretende com as licenciaturas? Em poucas palavras, que os futuros professores sejam bons alunos do nível que vão ensinar. Claro que depois tem a complementarização das disciplinas das unidades curriculares rela- 
cionadas com a didática, com as práticas. Mas no conhecimento matemático, que é o que vai sustentar o conhecimento didático ou pedagógico, o foco é no saber fazer. Portanto, para conseguir transcender as fronteiras da disciplina escolar para a área do conhecimento, a perspectiva será que o conhecimento matemático do futuro professor tenha atenção efetivamente nas especificidades da matemática para ensinar a matemática.

Nesse sentido, há duas dimensões que eu considero essenciais: uma refere-se ao conhecimento associado a formulação de problemas e outra refere-se ao conhecimento associado a atribuir significados e sentido matemático ao que os alunos dizem e o que os alunos fazem. Porque $90 \%$ do trabalho que nós fazemos enquanto professores é, ou deveria ser, o de ouvir os alunos e entender o que os alunos dizem e explorar o que os alunos dizem no sentido de promover a aprendizagem.

Eu digo deveria ser porque para mim o processo de ensino e aprendizagem não está associado ao que tradicionalmente se assume como tradicional, em que o professor sabe e o aluno aprende, ou ao que o professor sabe e o aluno ouve. Mas em que o aluno, em seu processo de ensino e aprendizagem, corresponde ao dar oportunidade ao aluno efetivamente entender o que faz porque, porque faz, como faz, tendo a perspectiva de futuro. Portando associar estas duas dimensões, a formulação do problema e o conhecimento interpretativo, seriam os dois eixos centrais da formação do professor, tanto inicial como continuada.

Perguntam-me como acontecer esta formação ou reformação dos profissionais da educação. Nós já sabemos que fornecer receitas não funciona. Apesar de ser isto que a maioria dos professores deseja ou está a espera quando alguém oferece uma formação. Já sabemos que levar tarefas ou atividades para formação, prontas para serem aplicadas - que é o que os professores esperam, mas que não funcionam. Já sabemos que virem uma séria de normativas, tanto do governo a dizer como deve ser a prática também não funciona. Porque enquanto nós não nos apropriarmos efetivamente de que o que fazemos - que muitas vezes corresponde a replicar a forma como aprendemos quando éramos alunos-, não contribui para a formação matemática dos cidadãos de hoje, pensando não só no hoje mas também no amanhã, não adianta virem as tais regras de cima que as coisas não mudam.

Portanto, quais as particularidades? Como fazer a formação, em primeiro lugar há necessidade que a formação se foque onde é efetivamente necessária, o que eu quero dizer com isso, nós perguntamos para as pessoas de uma escola "o que é que vocês querem discutir?", a grande maioria das vezes a maioria das pessoas preferem discutir coisas que já sabem. Ou seja, se perguntarmos "vamos ter uma formação, preferem de números ou de geometria?", todos os professores escolhem números porque é muito mais fácil. Porque se eu já me sinto à vontade em números, corro muito menos o risco de ser surpreendido e de ter que reconhecer de que não sei e de ter uma formação de geometria que 
tradicionalmente é um dos temas mais difíceis tanto para os alunos quanto para os professores.

Nesse sentido entra a pesquisa e o papel da pesquisa que nos dizem quais são as áreas mais críticas, tanto das aprendizagens dos alunos como dos conhecimentos do professor. Por outro lado, a formação tem a preocupação de explorar tanto as especificidades da matemática como fazer com que as tarefas que são exploradas nesta formação tenham significado para os próprios professores. Ou seja, explorar questões, explorar situações com as quais os professores se identifiquem, não que possam levar a tal receita, mas que possam levar imediatamente para a sala de aula, mas que identifiquem com algo que poderia ocorrer na sua sala de aula.

Isto leva-me a pensar no tipo de atividade, ou no tipo de tarefas que poderiam ou que deveriam ser discutidas nestas formações. Darei alguns exemplos que são tipos de coisas que costumo fazer.

Portanto, tarefas que partam - quando falo em tarefas me refiro aquilo que o professor prepara, atividade será aquilo que o aluno resolve. Eu como formador, que tipo de tarefas que proponho e que acho que são mais adequadas para permitir transcender esta disciplina escolar e área de conhecimento. Tarefas que tenham como ponto de partida respostas de alunos em determinada questão que levem a que os professores tenham que atribuir sentido aquilo que está feito. E que leve a uma discussão sobre que feedback eu vou dar ao aluno que deu esta resposta.

A análise de vídeos que promova o desenvolvimento do professional noticing e outro aspecto, discussão e elaboração do que nós chamamos de vinhetas, que tem a ver com situações que podem ocorrer na minha sala de aula, mas que eu vou explorar, vou elaborar no sentido de discutir tanto o conhecimento matemático, mas articulado com o conhecimento didático ou pedagógico. Elaborar este tipo de atividades, de tarefas, que permitam pensar na matemática que eu vou ter que ensinar relacionada com a matemática do nível mais avançado.

Corresponde ao que o Felix Land refere de matemática avançada do ponto de vista elementar e matemática elementar do ponto de vista avançado.

\section{Apresentação da Profa. Maria Helena de Souza:}

Prof. Adilson Dalben:

Agora contaremos com a explanação da professora Maria Helena, que recebeu as seguintes questões:

1) Atualmente, está mais evidente que os direitos das crianças não estão sendo garantidos, dada a não aprendizagem frequentemente constatada, inclusive nas salas de aula. Essa afirmação permite inferir que alguém não está cumprindo o seu dever e que, certamente, não é a es- 
colas e nem o professor. Afinal, ambos não têm, em geral, as condições para garantir as aprendizagens de seus alunos. Se a matemática enquanto disciplina já não está sendo garantida, uma proposta de enfoque como área de conhecimento, que aumenta a complexidade e a necessidade de recursos garantirá?

2) Como problematizar ideias, conectá-las com a história da humanidade, sem reduzi-la a um tema transversal? Quais aspectos diferenciam a matemática desenvolvida na área do conhecimento da matemática da matemática desenvolvida como tema transversal?

\section{Profa. Maria Helena de Souza:}

Em primeiro lugar gostaria de agradecer muito este convite e segundo - e não por ordem de importância-, aos textos que eu li, que foram um presente. Em relação às perguntas, acho que uma parte já foi muito bem respondida pelo Miguel Ribeiro: os eixos, os focos, as vinhetas, as tarefas acho que irão ajuda a gente a pensar.

Eu não vejo que os direitos de aprendizagem sejam tão mínimos assim, eu não consigo ver isto. Acho que sou uma romântica incurável. Eu passei este período de agosto até ontem, visitando a DRES - diretorias regionais da rede municipal-, e vi coisas maravilhosas: escolas quentes, com coisas penduradas, com a matemática espalhada em todos os lugares, com as salas de leitura sendo utilizadas de uma forma intensa. Inclusive há uma escola chamada Fonteneli que tem a grade diferente, os horários. Eu não vejo que os direitos estão assim tão jogados.

Agora nós estamos vivendo um momento que eu acho bastante difícil, por exemplo, uma escola muito conceituada do Butantã que é a Amorim Lima, que foi acusada por um vereador que entrou com uma ação, porque haveria uma semana de estudos de gêneros e acharam que isto seria uma coisa absolutamente na linha da escola sem partido. Este é um momento difícil, mas nós temos que lembrar algumas coisas, por exemplo, o Luc Ferry em "A inovação destruidora" ele diz assim: "o medo nos torna tolos e maus, incapazes de pensar livremente ou de nos abrir ao outro". Então os direitos humanos estão conectados aos direitos de aprendizagem, portanto este trabalho com direitos faz diferença. São caracterizados por lutas e defesas de novas liberdades. É o que precisamos levar em conta neste momento de temores, e também os conhecimentos de matemática que vão além destas coisas todas citadas pelo Antônio Miguel que é a parte qualitativa do ensino da matemática - e eu acho isto superimportante.

O Giambattista Vico dizia que é necessário toda a forma, imaginação, fantasia, engenho e poesia - e até mesmo os mitos. E considerava, como o Menezes, a História como a rainha das áreas do conhecimento; mas eu acho que matemática está ali lado a lado. Até mesmo porque as grandes ideias de mate- 
mática se expandem para as outras áreas de conhecimento, então ela está bem plantada com todos os seus braços invadindo as outras áreas de conhecimento. Também não acho que a garantia de direitos de aprender nesta concepção aumente a complexidade e nem a necessidade de mais recursos - humanos ou não. Mas sempre haverá a necessidade de diálogo entre gestores, professores, comunidade e, sobretudo, cuidados com as políticas públicas. Porque matemática é produto de práticas sociais, e isto não podemos esquecer.

O trabalho de matemática, o conhecimento matemático é pessoal, mas ele não é individual, ele é coletivo. O que dá a matemática a sua força. Mas também a gente precisa tomar cuidado com a formação do professor, não só a formação, mas também o que o Menezes chama de fortalecimento, que é contínuo e faz expandir as visões dos professores de matemática.

A segunda questão que fala sobre a matemática, diz que pode ser vista como mais um tema transversal - e os temas transversais são velhos conhecidos pelos PCNs. Só que eu acho que é o contrário. A matemática se apoia nos temas, sobretudo na ética, e transcende aos temas. Ela se vale deles e se expande, e a proposta de conexão da história da humanidade e as diversas culturas com a matemática, além do apoio dos direitos humanos, pede como Bloch, buscar uma utopia concreta - que faz parte do "ainda não", mas de forma consciente. E é um grande desafio, segundo eu li, o Bloch passou a vida dele perseguindo este tema.

É bom termos esta possibilidade, a de desejar uma utopia do "ainda não" com o pé no presente. É muito ruim pensar só no futuro. Saber fazer matemática está em plena conexão com as áreas de conhecimento, com as outras linguagens e com o mundo real; isto é fazer matemática do ponto de vista de área do conhecimento. A educação para todos como princípio, perspectivada pelos direitos humanos, significa levar às últimas consequências a ideia como direito constitucional sobre o qual todos os novos seres têm de participar da herança simbólica pública e assim ser novo no mundo para um processo educativo. E eu vejo a matemática muito bem colocada nesta situação.

Neste contexto insere-se a matemática nos direitos de aprendizagem e que saem da mera expectativa do "esperar que" para o direito de adquirir, nesta linha muito bem colocada pelo Antônio Miguel.

\section{Apresentação da Profa. Cristian Cerri}

Prof. Adilson Dalben:

A terceira professora a participar é a professora Cristina Cerri. Ela buscará responder às seguintes questões:

1) Reformas de programas de ensino e materiais para subsidiar os trabalhos dos professores "atravancam" o desenvolvimento da matemáti- 
ca como área do conhecimento. Como devem ser pensados e elaborados os programas de ensino e materiais para que matemática seja desenvolvida como área do conhecimento e não recaia novamente na escolarização?

2) A avaliação é tema de grande discussão e de tabu nas escolas, sendo ainda, em sua maioria, classificatória e excludente (principalmente nos exames vestibulares). Como deve ser avaliação nas escolas ao se trabalhar com área de conhecimento? Nesse contexto, como ficariam os exames vestibulares, inclusive o ENEM? Essas avaliações poderiam ser um meio de força a adoção da matemática como área de conhecimento?

\section{Profa. Cristina Cerri:}

Queria agradecer o convite, me sinto lisonjeada por dividir esta pessoa com pessoas tão importantes para a minha formação e agradecer esta oportunidade de discutir com vocês e dividir com vocês também preocupações que a gente também tem como formador, como profissional da área e então eu trago não só resposta como também perguntas e inquietações.

Bom, a minha experiência na área se dá inicialmente por ter feito licenciatura em matemática e depois entrei no mestrado e doutorado em matemática, sempre pensando na área de ensino. Comecei a trabalhar com formação de professores, por isso sou hoje diretora CAEM - Centro de Aperfeiçoamento de Ensino de Matemática da USP. Com isso a gente tem muito mais contato e proximidade com o professor, com a prática e isto leva a gente a discutir várias questões também da Aline, que é também membro do CAEM, que ajuda a gente muito neste contato com a escola pública e com os problemas todos relacionados ao ensino.

E, por esta prática eu vou tentar discutir um pouco estas questões que foram colocadas. Uma experiência que a gente teve a algum tempo foi um grupo de trabalho que nós fizemos no CAEM, sobre o currículo do ensino médio, então a gente criou o GETEM e ficamos por algum tempo discutindo como seria o currículo e o ensino médio. E a gente percebe que tem realmente dificuldades de definir os objetivos do ensino médio, e quais seriam os temas que deveriam ser tratados.

Assim, começamos a discutir, a listar e a refletir que matemática seria interessante trabalhar, como trabalhar estes conteúdos, a conexão destes conteúdos com as outras áreas, e a gente começou a elaborar e começou a definir alguns temas e perceber a importância atual da matemática. Percebemos que não tinha matemática material. Se você vai propor um problema, por exemplo, "como funciona o celular?", "como funciona o GPS?", e aí naturalmente deste tipo de problema surge várias áreas envolvidas, não só a matemática. 
Desta falta de material para o professor, chegamos à conclusão que precisávamos escrever o material, mas aí quando a gente resolve escrever, a gente engessa. Muitas das ansiedades dos professores que nos procuram é para nós oferecermos uma receita, um material pronto para eles trabalharem matemática de uma forma interessante, de forma contextualizada, ampla. E a gente vê a necessidade do material, do guia, do roteiro.

A gente acaba se perguntando: "mas isto não engessa?", "Isto na verdade não tolhe a criatividade do professor?". Hoje a gente percebe que a matemática que é feita ela é baseada no livro didático, que passou a ser o guia, passou a ser o programa que é aplicado. E para trabalhar a questão que foi colocada, a questão da matemática como área de conhecimento me fez pensar como nós vamos trabalhar isto.

Comecei a perceber que é preciso que o professor tenha autonomia, que ele tenha possibilidade de criar. E aí talvez a gente esteja querendo dar uma receita que não tem. Que é necessário dar ao professor a liberdade, e para isto entro na questão que foi colocada pelo Carlos, que é sobre a formação. Então a importância de se trabalhar a formação do professor, trabalhar o conhecimento matemático associado a prática, quer dizer, dar para ela realmente a liberdade, trabalhar isto e depois contextualizar na escola, dentro de seus limites.

Acho que as reformas de programas e os materiais, devem dar ideias gerais, mas não devem ser uma receita para se trabalhar matemática como área de conhecimento. Exatamente para não cair na escolarização. Outro tema que foi colocado é a questão da avaliação. É um tema bastante delicado e bastante atual. Neste contexto, como é que a gente avalia o aluno? Aí a gente toca em um outro tipo de problema que é na verdade "o que é a avaliação?" No contexto que a gente vive.

A questão colocou exemplos como exames vestibulares, ENEM e as transformações que esta avaliação sofreu ao longo dos anos. Trabalhar a matemática como área de conhecimento, de fato, tem que mudar a forma de avaliar o aluno ao final da educação básica. Por outro lado, isto acaba contaminando esta avaliação.

E outra questão é a questão dos exames vestibulares, que é de outra natureza, afinal, os exames vestibulares eles têm uma função que é selecionar alunos, dado que não há vagas para todos. Então dentro deste objetivo temos vestibulares de vários formatos e o interesse do aluno em entrar no ensino superior leva ele a se preparar para determinados exames: o exame do ITA é de um jeito, o exame da FUVEST de outro, da UNICAMP é de outro. E de alguma forma elas ficam contaminadas com uma mudança de enfoque no ensino básico. Mas também eu acho que é um processo lento e também o objetivo dos exames vestibulares é outro, não é de avaliar e sim de fazer uma seleção.

Enfim, é claro que as avaliações vão sendo contaminadas por essas mudanças. Mas é um processo absolutamente lento. 
Eu queria terminar com uma reflexão do Klein quando ele escreveu o livro tratando dos temas de matemática elementar sob um ponto de vista avançado ele diz: "minha tarefa será sempre mostrar-lhes a mútua conexão entre problemas em variadas áreas, desta maneira espero facilitar-lhes a aquisição da habilidade para obter da grande massa de conhecimento estimulo vivo para ensino".

Por isto que eu volto a dizer que os materiais estão aí, eles já existem. Então acho que o que é preciso é dar ao professor a liberdade e condições de compreender e de formar a sua trajetória como professor dentro da sala de aula.

\section{Apresentação da Profa. Ana Lucia Manrique.}

Prof. Adilson Dalben:

Agora é a vez da professora Ana Lúcia Manrique responder às seguintes questões:

1) Como organizar o trabalho nas escolas de Educação Básica para que ela realmente para que ela possa ser considerada uma área de conhecimento?

2) Essa organização do Ensino da Matemática a descaracterizaria como uma disciplina escolar? Um trabalho interdisciplinar na disciplina de matemática, não poderia ser considerado um ensino por área de conhecimento?

Profa. Ana Lúcia Manrique:

Primeiramente quero agradecer o convite feito pelo Adilson para fazer parte desta mesa. Esta não é uma temática que eu trabalho - pensar sobre a área de conhecimento-, eu trabalho com a formação de professores, atualmente também tenho trabalhado com a questão da educação matemática inclusiva.

As minhas reflexões têm por base a minha área de atuação. Lendo os textos percebi que cada um abordou uma temática diferente e para mim foi um desafio. Elaborei um texto pensando nas questões que foram colocadas para mim: "como organizar o trabalho nas escolas", é algo bastante difícil quando eu penso na área de conhecimento matemático.

Eu entendo a matemática como uma área de conhecimento, entendo os conteúdos, e entendo que para trabalhar matemática na escola eu preciso de algo além dos conhecimentos da matemática, preciso de muitos outros elementos. Pensando sobre esta questão de como organizar o trabalho nas escolas para que ela seja considerada como área de conhecimento, eu fiquei imaginando que não é algo simples. 
O professor não tem autonomia de como trabalhar este conteúdo, porque a demanda que ele possui na sala de aula é muito diversificada. Então com estas questões atuais sobre a inclusão, o trabalho do professor para ensinar a matemática em sala de aula se tornou muito mais complexo. Ele já era complexo, a gente já tinha muitas discussões sobre esta questão, agora temos uma enorme demanda para receitas, como trabalhar com uma criança com síndrome de Down, como trabalhar com uma criança com discalculia, cega, surda dentro da sala de aula. Estas questões elas estão dominando também o dia a dia do professor.

Como organizar este trabalho nas escolas? Eu considero que o trabalho deveria ser coletivo, embora a gente tenha esta ideia de que o professor entra na sala de aula e trabalhará os conteúdos com os seus alunos, eu acho que deveria ter sempre trabalhos coletivos, com outros professores, principalmente considerando a matemática. A matemática pode ser utilizada na química, na física, nas ciências, na história, na geografia, por isso acho que o trabalho do professor deveria contemplar projetos, atividades investigativas em que a matemática não ficasse só pela matemática.

A professora Cristina deu um exemplo de trabalhar com GPS, com o celular, não tem como o professor de matemática fazer isto sozinho. A gente precisa trabalhar coletivamente, é um pouco dessas questões também que a gente tem que trazer. Os cursos aqui talvez promovam um pouco desta coletividade da escola, trabalhando com professores de outras áreas. A escola deveria trabalhar com projetos, mas não existe uma receita de projetos, não existe um modelo, o professor vai precisar sim ter autonomia de pensar nos alunos que ele possui e o contexto que a escola está inserida para propor os problemas que sejam motivadores para que esses alunos participem e se envolvam nestas questões. E que sejam atividades que as crianças e adolescentes queiram participar.

Então a matemática é uma maneira de atingir essas crianças e estes adolescentes, no sentido de que ela propõe uma forma de pensar diferente sobre as situações que estão colocadas. Pensar o GPS matematicamente, o que está por trás, é uma forma diferente de pensar o que é o GPS para nós. Hoje a gente pega o GPS no celular para ir em qualquer lugar - para ir daqui ao trabalho eu pego o GPS para saber qual o melhor caminho-, então não é só uma utilidade, ele tem uma razão. Se tirar o GPS de mão de algumas pessoas, algumas não sabem mais voltar para casa, param de se locomover. Entender os mecanismos das ferramentas, das tecnologias que hoje nos circulam é muito importante e motivador para os alunos.

A segunda questão, se esta organização do ensino a descaracterizaria como uma disciplina escolar. Eu penso que não, porque em primeiro lugar quando você pensa na organização do ensino desta maneira, as pessoas devem conhecer os professores muito bem no campo que ele atua, para ele pode contribuir com o outro. Não é o outro que tem resposta, é o coletivo que encontrará a resposta. Então se eu me proponho a participar de um grupo interdiscipli- 
nar com pessoas e professores de outras áreas, significa que eu vou contribuir com a minha parte. Também existe uma questão aí do professor entender que não vai saber tudo sobre aquele projeto, que ele não tem que entrar no projeto já sabendo quais são as respostas e sim em uma atitude investigativa, para coletivamente acharmos respostas e as respostas às vezes elas estão encaminhadas pelas outras áreas pelos outros conhecimentos dos outros professores que vão contribuir para que o meu conhecimento sobre aquele projeto que estou participando ele se altere.

Como complementação desta segunda questão, o trabalho interdisciplinar pode ser considerado como um ensino da área de conhecimento, porque cada um com os seus conhecimentos contribuirá para um conhecimento coletivo. Práticas sociais são construídas coletivamente, não só as ciências. As práticas sociais são compostas por diversos elementos e elas são complexas, olhando-as com a matemática, estamos olhando com uma lente, com uma forma só de ver, de uma maneira filtrada.

Apresentação do Prof. Nilson José Machado.

Prof. Adilson Dalben:

Agora é a vez do Professor Nilson José Machado, que recebeu as seguintes questões dos alunos:

1) É fato que a excessiva fragmentação e a falta de articulação entre os conteúdos em nossas escolas e sistemas de ensino. De que maneira desenvolver projetos, considerando a matemática como área do conhecimento, atendendo interesses dos alunos, atingindo expectativas de ensino e aprendizagem, sem instrumentalizá-la, sem empobrecer o uso corrente da língua e desconstruindo a fragmentação?

2) De todo o exposto e tratado nos textos, objetivamente, quais são os elementos que permitiriam classificar "algo" como "área de conhecimento"?

Prof. Nilson José Machado.

Agradeço o convite para estar aqui, acho que o SESI em uma iniciativa absolutamente pioneira nesta questão da formação do professor por área e está promovendo esta discussão do que é uma área e por que nós é que estamos sendo afetados no que se refere nesta classificação de área com a grande mudança do Estatuto de Disciplina para o Estatuto de Área, as outras áreas estão aí desde os PCNs - as áreas de linguagem queriam incluir a matemática-, mas esta discussão já estava posta lá. 
No currículo do Estado de São Paulo de 2008 esta discussão foi posta de uma maneira bem lúcida e tudo pela secretária Helena que exigiu que no currículo de matemática existisse pelo menos uma página com uma justificativa do porquê a matemática ser uma área. Foi a primeira vez que a gente foi obrigado a colocar no papel porquê a matemática é uma área.

Bom, eu gostaria de falar de uma maneira mais geral, menos especifica sobre estas situações do currículo de São Paulo. Queria discutir fenomenologicamente a questão: a gente tem como fenômeno a fragmentação disciplinar. $\mathrm{O}$ que parece esta unanimidade, todo mundo querendo uma reforma do ensino médio e tudo, o que parece que une todo mundo é a constatação de que a fragmentação disciplinar é excessiva. Disciplina não é um problema, nunca foi. A escola sempre foi disciplinar, e acho que vai continuar a ser. Não é este o problema, o problema é a fragmentação, o excesso, o descaminho até onde isto levou.

Há dois tipos de ações que podem ser implementadas. A gente está vendo uma, que é consertar a fragmentação. A criação de áreas desde os PCNs tem esta intenção de diminuir os efeitos, de consertar o que já se quebrou. As vezes este conserto é artificial. Por exemplo, lá nos PCNs colocaram a matemática dentro da área de Ciências da Natureza, e isto era um atestado de óbito que não correspondia a nenhum defunto, porque como documento era isto, mas na prática não houve colégio que assumisse isto como a matemática dentro das Ciências da Natureza. Mas são iniciativas interessantes para consertar o que está quebrado.

Outro tipo de iniciativa, que a gente tem visto menos que é o de evitar que se quebre. Porque uma criança de três, quatro anos não tem fragmentação disciplinar para ela. Ela fala que tem três anos e está aprendendo a falar, e os números, é tudo forma de expressão, ela não tem fragmentação. Um boletim de creche é exemplar, é a pessoa como um todo. A gente começa a ter drama no ensino médio, no fim do fundamental, onde a nota vermelha nesta, naquela matéria... aí você não é mais professor de criança, é professor de matéria.

Essas ações para evitar a fragmentação, elas independem da criação de áreas. A gente poderia manter exatamente as matérias que estão aí e ter ações para combater a fragmentação, não precisaria de área. Por exemplo, construir a consciência de que as disciplinas perderam, em geral, o discernimento do que é fundamental e do que é "penduricalho". É só pegar um livro do Ensino Médio que a gente percebe. Diante de um livro de Biologia, de Física, de Química a gente se sente ignorante. Porque saiu do controle, são muitos pormenores e o que é fundamental fica escondido porque se os livros didáticos, os programas, os currículos e a escola trabalhassem o fundamental não teria sentido a gente se sentir ignorante diante de um livro de Biologia, Física, Química ou de qualquer matéria do Ensino Médio. Algo está errado.

Só que não estamos aqui para discutir esta vertente. Bom, as perguntas que me foram feitas sobre estas ações para consertar a fragmentação são basica- 
mente duas e bem interessantes. A primeira é: "quais são os elementos que permitiriam classificar algo como uma área do conhecimento?”. Bem, para falar de área de conhecimento é preciso falar de volume porque a área do conhecimento é um mapa, é uma representação plana (área)... é você pegar o mundo e dizer que tem a África, tem a América, tem regiões recobrindo um território; é ver no território do conhecimento quais são estas grandes regiões. Porém o mapa não é a realidade, e a gente dá aula de conteúdo, conteúdo lembra volume, a gente precisa de volume. E este volume é que dará sentido a estas áreas.

Neste volume é que entra a questão das ideias fundamentais. Seja qual for a configuração do currículo, a gente possui ideias fundamentais, articuladoras. Por exemplo na física a gente possui a ideia de energia, que aproxima a física, da química, da biologia, da geografia. Ou seja, há um elenco de ideias fundamentais da física que são importantes na formação de qualquer cidadão, não só na formação do físico. Em qualquer disciplina existe isto, e essas ideias elas nunca são estritamente disciplinares, por exemplo, a energia por mais que a gente situe na física, ela não é propriedade privada da física, ela é importante na química, na biologia, etc.

Eu busco fundamento em uma disciplina, mas aquilo que é realmente fundamento transborda a fronteira da disciplina e eu acabo falando de outras matérias. Esse é um ponto importante porque antigamente a gente estudava física, mas sem estudar a estrutura, quando quebrávamos virava química. Então a gente está querendo sair disto e precisamos encontrar este elenco de ideias fundamentais para dar volume a esta representação por área.

São três coisas que nos levam a chamar algo de área: as ideias fundamentais em torno das quais o currículo todo se baseia, mas nunca são estritamente disciplinares. A ideia de mapa é uma ideia que nasce na geografia como cartografia e hora a gente vive a ideia de mapa em qualquer área do conhecimento. Outra coisa para caracterizar como área é um conjunto de ferramentas para servir a ciência como um todo, e por último, tem que possuir uma linguagem (a linguagem matemática, a linguagem da ciência, etc.) e uma maneira das ideias circularem neste território.

No caso da matemática, eu diria que quando a gente faz uma lista de conteúdos como: número, geometria, álgebra, etc. Isto as vezes esconde as ideias, ou seja, o conteúdo corre o risco de se transformar no fim, o que na realidade, na escola básica, qualquer conteúdo é meio. A lista de conteúdo não faz mal, mas é precisa explicitar nesta lista de conteúdos quais são as ideias que são o fundamento. A gente estuda trigonometria, mas a ideia de proporcionalidade é uma ideia que estou passando pela trigonometria e a ideia de periodicidade, de representação dos fenômenos periódicos... são poucas as ideias fundamentais. Ficar resolvendo "500" equações trigonométricas, isso tudo é delírio; resolver equações com módulo dentro de módulo é delírio.

Então, no caso na matemática a gente trabalha os conteúdos mais nas perspectivas das ideias fundamentais, mas acredito que atualmente para justifi- 
car uma área de matemática era preciso que a gente assumisse a responsabilidade por três outras classes de ideias que já foram nossas, mas foram ficando marginalizadas com o tempo.

$\mathrm{Na}$ área de matemática, além desde conteúdo de matemática, eu diria que a parte de lógica, a argumentação, tinha que estar mais explicitamente presente no conteúdo de matemática. Assim como estatística, probabilidade, são conteúdos que já são trabalhados, mas precisam ser trabalhadas com muito mais ênfase. Por exemplo, se uma criança na sala die aula dizer que $2+3=7 \mathrm{com}$ margem de erro de dois pontos percentuais a gente não vai aceitar, mas acho que deveríamos aceitar. Por último, considero também a parte de tecnologia, a gente em matemática tem condição de acolher muito mais eficazmente as coisas que vem da tecnologia. O uso com consciência da tecnologia. Estes 3 pilares engordariam este conteúdo de matemática como área: a lógica, a estatística e as tecnologias.

\section{Apresentação do Prof. Antônio Miguel.}

Prof. Adilson Dalben:

Para encerrar essa primeira rodada vamos agora contar com a explanação do professor Antônio Miguel. Ele recebeu as seguintes perguntas de nossos alunos da pós-graduação:

1) Suas reflexões apontam para uma organização não disciplinar para a construção do Conhecimento. Em que medida o senhor acha exequível essa proposta considerando o atual contexto educacional (constituído historicamente)?

2) Um exercício de inversão de papéis: Se o senhor fosse atualmente responsável pela elaboração curricular de uma escola, de um município, de um estado ou do Brasil, qual seria a crítica que faria a seu texto?

Prof. Antônio Miguel:

Quando o Adilson me convidou para esta mesa eu me senti desafiado, especialmente porque ele me havia informado teria que aqui novos cursos de licenciatura, em novos formatos, baseadas em áreas de conhecimento. E eu já vinha, naquele momento - pelo trabalho que estava fazendo na UNICAMP junto aos cursos de licenciatura, bem como em nível de Pós-Graduação -, estabelecendo um intenso de diálogo com as obras de Wittgenstein e de Derrida, dois filósofos bastante incisivos.

O convite, então, me desafiou a pensar, porque eu já tinha uma crítica em relação aos modos de se organizar o conhecimento, as aulas, a formação de professores com base em áreas de conhecimento. Então, eu já me coloco como 
uma pessoa que iria olhar com olhares críticos para esta divisão, mas também a gente já tinha um trabalho acumulado na perspectiva da desconstrução da própria matemática como disciplina e, portanto, uma desconstrução da visão disciplinar do conhecimento e, até mesmo da visão epistemológica do modo como se organiza a educação escolar e a formação de professores.

O texto que produzi já traz no seu título esta diferença: Disciplinas ou áreas de conhecimento para que? Por uma formação terapêutico-indisciplinar do professor. É um texto muito longo, denso, no qual procurei trazer para o diálogo autores contemporâneos que estão discutindo questões relativas à nature$\mathrm{za}$, bem como às relações que se estabelecem entre natureza, cultura e política.

Os estudantes me perguntaram se as minhas reflexões apontam para uma organização não disciplinar da construção do conhecimento. E em que medida é exequível esta proposta considerando o atual contexto educacional.

De fato, embora a reflexão que eu tenha feito no meu texto seja bem mais uma argumentação desconstrucionista do regime disciplinar do que propriamente uma proposta de escolarização indisciplinar, esta reflexão não se constituiu, evidentemente, do dia para a noite e nem pode ser vista como devaneio ou utopia.

Mesmo porque, uma escola disciplinar não pode ser consequentemente desafiada meramente pelo verbalismo das palavras. Então, o trabalho que temos realizado tem um lastro; e, quando falamos em exequibilidade, estamos com isto querendo acenar para a possibilidade de operacionalização, de efetivação, de viabilização prática, de realização de percursos indisciplinares, tanto na formação do professor quanto nas nossas aulas na educação básica, como também realizar percursos indisciplinares ao nível da pesquisa acadêmica. Esses percursos têm sido feitos por mim em colaboração com os meus orientandos e também em parceria com alguns professores da Faculdade de Educação da Unicamp, tentando-se produzir percursos indisciplinares ao nível da pesquisa, da docência (na formação de professores) e nos estágios.

Existe uma particularidade dos cursos de licenciatura da UNICAMP, porque na reformulação que foi feita em tais cursos por volta de 2005, nós, professores da área de educação matemática da Faculdade de Educação, que sempre havíamos trabalhado com os estágios na área específica de ensino de matemática, acabamos perdendo a possibilidade de continuar um trabalho dessa natureza. Assim, nós, professores da área de educação matemática, que tradicionalmente desenvolvíamos projetos de estágios específicos junto a futuros professores de matemática, tivemos que passar a trabalhar com propostas não disciplinares de estágio. Então nossas turmas de estágio eram constituídas por estudantes provenientes de todos os cursos de licenciatura - da enfermagem, da música, da química, da física, matemática, da história, da filosofia etc. -, o que praticamente nos obrigou a ir para a escola, para as salas de aula da Educação Básica com uma proposta indisciplinar de estágio. 
Era este o grande desafio que resolvi enfrentar positivamente e, para isso, me associei com a professora Ana Regina de Moura e nós fizemos um projeto de estágio - porque os estágios, na Faculdade de Educação, se organizam com base em projetos - denominado Descontruindo a educação escolar disciplinar.

Portanto, aquele movimento que a gente vinha fazendo ao nível da pesquisa, também procuramos realizá-lo ao nível do estágio e vou ler aqui a ementa deste projeto de estágio, só para a gente ter uma ideia do que se trata:

Com base no desenvolvimento de projetos de investigação-ação em escolas de educação infantil de ensino fundamental e ensino médio, o projeto de estágio denominado Descontruindo a educação escolar disciplinar tem como propósito produzir conhecimentos que possam sustentar e viabilizar novas formas de educação escolar, não mais centradas no princípio de organização disciplinar da cultura escolar. Neste sentido, os projetos desconstrucionistas de investigação-ação a serem desenvolvidos pelos estudantes nas escolas deverão orientar-se não mais por dicotomias tais como teoria x prática, ensino $\mathrm{x}$ aprendizagem, forma $\mathrm{x}$ conteúdo, teoria $\mathrm{x}$ prática, disciplinar $\mathrm{x}$ interdisciplinar etc., mas por um novo princípio de organização e mobilização da cultura na escola, qual seja, o da problematização indisciplinar de práticas culturais que se realizam em diferentes campos de atividade humana. As práticas culturais que deverão orientar a produção dos projetos desconstrucionistas de investigaçãoação deverão ser eleitas com base no diálogo entre os pressupostos éticopolíticos e metodológico-conceituais que orientam este projeto de estágio e as demandas situadas nos diferentes campos de estágio. Por sua vez, a problematização indisciplinar a ser realizada nos diferentes campos de estágio pauta-se no princípio de deslocamento das práticas eleitas por diferentes campos e contextos de atividade humana. E uma vez que tais práticas e campos de atividade passam a constituir as unidades básicas orientadoras da ação pedagógica escolar, da formação de educadores para escola básica e da investigação em educação, conceitos tais como práticas culturais, jogos simbólicos e discursivos, atividade humana, problematização indisciplinar, comunidades de prática e modos de subjetivação se mostram básicos para o planejamento, desenvolvimento e avaliação dos diferentes trabalhos de inserção nos campos de estágio.

Ainda que a gente tenha enfrentado com este projeto, tanto na UNICAMP quanto nas escolas, todos os fatores adversos que se interpunham ao desenvolvimento desses projetos indisciplinares nas escolas, os alunos que optaram por participar deste nosso projeto de estágio, ao longo dos anos de 2010 a 2013, ao aceitarem desafiar suas próprias formações disciplinares, puderam minimamente vivenciar conosco o desafio de torná-los exequíveis para o projeto de formação indisciplinar na escola disciplinar que aí está. Projetos muito interessantes foram produzidos e desenvolvidos nas escolas, e o envolvimento 
demonstrado tanto por parte dos estagiários quanto por parte dos alunos das escolas atesta, de certo modo, que é possível, viável e exequível transgredir a escola produtivista e desagregadora que aí está, e nos tornarmos professores indisciplinares, desejosos e capacitados para promovermos a formação de cidadãos descolonizados.

Eu fiz questão de ler esta ementa para não ficar parecendo que as ideias relativamente densas que foram desenvolvidas no texto que escrevi para esta nossa conversa não tinham um lastro de exequibilidade ao nível do trabalho que temos realizado com os estágios. Essas ideias foram de fato trabalhadas. Então, quando vocês, alunos e professores desta casa, me perguntam se estas minhas reflexões apontam para uma organização indisciplinar da construção do conhecimento, então, um certo esclarecimento deve ser feito.

Antes de mais nada, embora o meu texto de fato questione e procure desconstruir políticas curriculares disciplinares para a nossa escola, ele não aponta para um tipo de escolarização epistemologicamente centrada, isto é, centrada no conhecimento. É exatamente assim que a configuração disciplinar do conhecimento vê o conhecimento e trata o conhecimento. O desafio é o de deslocar o centro de uma formação epistemologicamente centrada. Não se trata de uma nova proposta epistemológica, porque ela não toma como centro o conhecimento e, sobretudo, o conhecimento visto como algo estruturado; ao contrário, ela faz um deslocamento da ideia de conhecimento colocando no centro da ação pedagógica a ideia de práticas culturais, ou seja, o modo como as pessoas de fato praticam o conhecimento em todos os campos de atividade humana nos quais o conhecimento é produzido.

É muito importante dizer isso, porque a ideia que a gente tem do conhecimento e da própria virada epistemológica que se deu a partir do século XVIII é que os conhecimentos são produzidos cientificamente na Universidade, pelos cientistas, e que o resto da sociedade aplica o que a gente faz na Universidade. É uma visão totalmente enviesada da ideia de conhecimento. Na verdade, o conhecimento é produzido nos campos de atividade humana, nas formas de vida, e nas formas de se produzir a vida, que são constituídas ao longo de toda a história da humanidade. Só para se ter uma ideia, o campo da navegação vem se constituindo e se desenvolvendo desde a pré-história. Os conhecimentos em torno das práticas de navegação são constituídos neste grande campo que tem uma longevidade histórica através dos tempos. Conhecimentos são produzidos nestes campos e também na Universidade, através da pesquisa acadêmica. Mas a figura do matemático profissional é relativamente nova, é do século XIX. Assim, a ideia é não mais pensar a escola com base no construto epistemológico chamado conhecimento. O conhecimento é produzido nos campos de atividade humana. São tais campos e as práticas que neles se processam que tomamos como centro da nossa ação.

É preciso também darmos um certo esclarecimento em relação ao termo indisciplinar. Quando questionamos a pertinência e o valor formativo do 
conhecimento disciplinarmente configurado e passamos não só a falar, mas também a praticar a problematização indisciplinar como uma atitude educativa e formativa na escola e na formação do professor, isto não significa qualquer tipo de insubordinação profissional. Quando falo em atitude indisciplinar me refiro ao termo sugerido pelo linguista brasileiro Luís Paulo da Moita Lopes que aparece no título de um livro chamado Por uma linguística aplicada indisciplinar. O modo como o próprio autor mobiliza este termo no livro sugere que uma atitude indisciplinar não é apenas aquela que, voluntariamente, procura questionar e transgredir as fronteiras do conhecimento disciplinarmente configurado, mas, sobretudo, questionar e transgredir concepções estritamente epistemológicas, cientificistas, abstracionistas, apolíticas, ahistóricas, individualistas, cognitivistas e incorpóreas do conhecimento e da produção do conhecimento.

A nossa escola elabora avaliações que se dizem centradas em competências adquiridas pelos alunos. Mas, essas competências e habilidades sempre definidas com base na aquisição de um saber. É claro que, para mim, um tal modo de ver o conhecimento e, por extensão, o conhecimento matemático, está longe de ser minimamente representativa do modo como os professores, cientistas, pais, alunos e nós mesmos costumamos ver o conhecimento. Não existe uma representatividade neste sentido.

Quando a gente fala em exequibilidade desta formação indisciplinar, a gente está querendo se referir ao modo como a nossa escola disciplinar se configurou desde, pelo menos, a reforma Benjamin Constant, logo após a proclamação da República. Desde então, nós nunca tivemos a oportunidade de vivenciar uma experiência de organização curricular indisciplinar na escola. Todas as reformas - e foram muitas - estiveram centradas na ideia de conhecimento disciplinarmente configurado, de modo que a postura disciplinar está presente na gênese da escola moderna, e é muito difícil desafiá-la neste nível, o que não significa que as nossas ideias não tenham uma certa exequibilidade

\section{Prof. Luis Carlos de Menezes.}

Eu gostaria de fazer dois comentários sobre a ideia de matemática como área comparando com as demais áreas - em um sentido menos filosófico e mais da organização do conhecimento escolar. As demais áreas se caracterizam primeiro por reconhecer em seus componentes e em seguida verificar como é que ela com os seus componentes se relaciona com as demais áreas, pensando as práticas sociais e as culturas desenvolvidas na escola.

Os componentes da matemática soam mais ou menos extensivos, já mencionados aqui? Estatista, geometria, álgebra, etc. Tem sua especificidade, não são singulares, mas eles se relacionam, e reconhecer a especificidade dos seus componentes me parece muito importante pra matemática se entender como área, e em seguida verificar a sua relação com as demais áreas. 
$\mathrm{Na}$ fala de abertura da Maria Helena ela dizia "com as outras linguagens", quer dizer, ela já está se entendendo como linguagem, a matemática como linguagem que se relaciona com outras linguagens, por exemplo se pensarmos em uma linguagem que seria da música, a matemática e a música quase que nascem juntas quando você pensa no pensamento grego. Ela é linguagem essencial, talvez uma das mais belas e filosóficas percepções da física tenha sido feita por uma matemática no século XX, que diz que toda vez que temos um princípio de conservação - a física está fundada nisto -, você tem associado a isto uma ideia de simetria do espaço e de tempo. E energia, que mencionou o Nilson, a energia se conserva porque o tempo é uniforme. A uniformidade do tempo é sinônimo de conservação de energia, se o tempo não fosse uniforme primeiro os recordes olímpicos dançavam todos, porque em um ano ou minuto, o segundo valeria diferente. Mas também as unidades de energia, tudo ficaria bagunçado.

Esta percepção de ter um princípio de conservação e simetria do espaço e do tempo é essencial e fundamental para física e, portanto, para todas as demais ciências. Esta percepção de como a matemática se relaciona com as demais ciências é muito importante. Para situar um avião ou uma cidade, você pega uma latitude e uma longitude e está usando uma coordenada esférica associada a geografia. No caso da história recentemente nós trabalhamos evolução dos cosmos, da vida e do ser humano... então estou chamando atenção para dois aspectos simples: reconhecer-se como área identificando os seus componentes e depois estabelecer os vínculos e as ligações com as demais áreas do conhecimento, acompanhando a perspectiva que o Miguel levantou; não se trata simplesmente de dar contexto, trata-se sim de estabelecer a ligação. 


\title{
DÚVIDAS, RESPOSTAS E DESAFIOS PARA A FORMAÇÃO DE PROFESSORES POR ÁREA DE CONHECIMENTO*
}

\begin{abstract}
Abertura: Prof. Adilson Dalben.
Nesta segunda parte de nossa dinâmica, cada um dos participantes terá um tempo para suas considerações finais que poderão ser feitas considerando a seguinte provocação metafórica proposta pelo professor Menezes:

Se imaginarmos que cada uma das faces de um tetraedro representasse uma das áreas de conhecimento (Ciências da Natureza, Ciências Humanas, Linguagem e Matemática), cujo núcleo seria preenchido por cultura e práticas sociais, este sólido seria uma boa representação da proposta de formação dos profissionais da educação da Faculdade SESI-SP de Educação?
\end{abstract}

\section{Análise do Prof. Miguel Ribeiro.}

O ler a frase do Menezes eu quase que concordo. E o porquê do quase? Em particular gosto de representações geométricas, neste sentido concordo. Concordo que o tetraedro é efetivamente uma excelente forma de representar as relações e conexões que tem que necessariamente existir entre as diferentes áreas. Não sei se concordo com o núcleo ser totalmente preenchido com a cultura e prática social.

Se este núcleo for considerado uma esfera inscrita no tetraedro, em que há mais espaço fora do tetraedro eu concordo. Se o núcleo for exatamente o interior do tetraedro, sou levado a discordar. Não vou referir explicitamente o porquê, mas vou apontar alguns pontos desta discórdia.

Pensando no núcleo como cultura e práticas sociais, eu vejo a educação como uma prática social, o ensino como uma prática social que ocorre em determinada comunidade prática. Portando tudo isto é situado no contexto específico e implica também que a formação tenha consideração a este conceito específico. Efetivamente tudo está conectado com tudo e uso a palavra "conectado" no sentido de trazer a matemática em termos do conjunto conexo.

A nossa própria localização geografia, temporal tem implicações na forma como encaramos as conexões entre as diferentes áreas do saber. Isto levame a pensar no trabalho que os colegas italianos estão a desenvolver que atribuem o nome de transposição cultural; não transposição no sentido da didática

*10.29388/978-85-53111-95-4-0-f.99-112 
francesa, mas da situacionalidade das atividades que são desenvolvidas na cultura específica em que são desenvolvidas.

Isto traz para a discussão a matemática no ensino e o ensino da matemática, que à primeira vista pode parecer o mesmo, mas para mim são coisas substancialmente distintas. Se nós falarmos no ensino da matemática, podemos pensar como eu vou ensinar aquela matemática, para eu pensar como eu vou ensinar esta matemática, tenho que trazer a matemática que efetivamente tem que ser ensinada. Que matemática é esta? Qual é o foco desta matemática que eu vou considerar? E pensando na área do conhecimento, que articulações eu faço entre esta matemática do modo a que esteja descompartimentalizada-, com as outras três faces do tetraedro? Que conexões eu consigo fazer? Que conhecimento como professor de matemática tenho que ter? Não só da matemática para permitir que não seja área de conhecimento-, mas que me permita fazer estas tais conexões com as outras três faces do tetraedro considerando a educação como prática social.

Este trazer a matemática e o conhecimento matemático para frente, pensar efetivamente que vão ensinar matemática e usar os recursos no sentido de intencionalidade com objetivo matemático. Necessariamente tem associada a necessidade de desenvolver não só um conhecimento sobre o saber fazer, mas que permita desenvolver uma prática social contribuindo para o desenvolvimento do conhecimento associado ao saber ou entender os porquês. Para entender os porquês eu tenho que saber fazer. Eu só entendo o porquê de fazer aquilo que faço se souber fazê-lo.

Mas o entender o porquê vai muito mais além do saber fazer. Por exemplo, por que determinado algoritmo de subtração funciona daquela forma? Tem relações necessariamente com a matemática avançada que nós aprendemos em um curso de estruturas algébricas. Será que nós como professores, e com a formação que temos, e nós próprios formadores quando damos esta formação temos estas preocupações de fazer estas conexões da matemática elementar e da matemática avançada?

No mesmo sentido, tenho a minha preocupação em fazer as conexões da matemática com as outras três faces do tetraedro. Será que nós neste momento efetivamente estamos em condições de dizer: "nós podemos dar uma disciplina escolar que permita efetivamente considerar as quatro faces do tetraedro de forma integrada".

Portanto, pensando na questão do núcleo, com a cultura e prática social, parece-me que cumprem a qualquer formação de professores desenvolver uma prática social que permita erradicar a cultura do uso excessivo e exclusivo do livro didático. E que permita erradicar a cultura da avaliação como um fim. Se nos desenvolvermos o conhecimento do professor especializado, o professor vai passar a ter muito mais recursos para utilizar do que apenas o livro didático. E quando falo recursos não são só recursos materiais, são recursos mentais (conhecimentos e saberes). E por fim, a questão da avaliação é essencial 
porque se eu vir a avaliação como um elemento punitivo, o meu foco de ensino será imediato e não uma perspectiva futura.

Para poder articular as quatro faces do tetraedro na minha perspectiva relaciona-se também com a avaliação. Porque se eu vou avaliar em prol das aprendizagens, não vou considerar em prol das aprendizagens apenas a matemática, considerarei em prol das aprendizagens integradas. Fazer esta integração que corresponderá ao núcleo do tetraedro será um desafio que efetivamente a formação de professores aqui do Sesi terá.

\section{Análise da Profa. Maria Helena de Souza.}

Eu estava trabalhando com os direitos de aprendizagem em um negócio que chama "Diálogos Interdisciplinares a caminho da autoria". E agora fiquei louca para ter os Diálogos Indisciplinares a caminho da autoria. Estamos preparando uma revisão do projeto pedagógico do curso de licenciatura em Matemática da Faculdade SESI-SP de Educação e aí descobri muitas coisas que não sei que existem em matemática. E o que a gente vai fazer com isto? Com este monte de coisa?

Quando fui pensar sobre o tetraedro em primeiro lugar pensei "tetraedro tem a esta base com 3, então tem equilíbrio" e aí li o texto do prof. Antônio Miguel e acabou com tudo. Eu tinha escrito: "o tetraedro proposto pelo Menezes, remete à coletividade de forma a articular e equilibrada que passa pela compreensão do passado e o estabelecimento de vínculos com o presente em busca da construção também de um presente afora de um futuro em que ocorra transformações sociais, e que estas respeitem as diferenças pessoais que promovam equidade, a justiça e o equilíbrio social e que possam construir convivências solidárias e não excludentes".

Apesar de parecer utópico, eu acho com uma certa veemência que é factível e sustentável, assim como você acha que a indisciplinaridade é factível e sustentável. Fiquei pensando no tetraedro, em que lugar deste tetraedro está o afeto? Porque não consigo entender o ensino básico sem as relações afetivas. Não existe. Portanto, pensei nos vértices, que são bem salientes; então as afetividades podem se distribuir ali pelos vértices. A conversa com as faces, eu pensei naqueles poliedros que a gente consegue desmontar.

Antigamente tinha uns tetraedros de achocolatados, você cortava a ponta e tomava. Eu fiquei pensando sobre o volume e o que mais a gente precisa dentro de um tetraedro. Que mais que a gente precisa? Ousar aprender, porque não é fácil, nunca é fácil. De verdade, eu gosto muito desta coisa mais humanizada com a área de conhecimento que é ferramenta, ciência e linguagem das mais belas. Então eu pensei e achei um poema que eu vou dedicar ao Menezes que é o Poema Dialético do Murilo Mendes:

Tudo no universo marcha, e marcha para esperar: 
Nossa existência é uma vasta expectação

Onde se tocam o princípio e o fim.

A terra terá que ser retalhada entre todos

E restituída em tempo à sua antiga harmonia.

Tudo marcha para a arquitetura perfeita.

A aurora é coletiva.

\section{Análise da Profa. Ana Lúcia Manrique.}

Eu quando li a frase afirmação feita pelo Menezes eu fiquei também pensando em vários aspectos sobre esta questão da formação de professores. Eu também pensei como o Carlos que teriam práticas sociais e culturas não só no singular, mas no plural, fora e dentro do tetraedro. Eu pensei neste tetraedro como lentes, como eu posso olhar com esta lente para dentro das práticas e das culturas que ocorrem nas escolas. Se eu olho por uma face estou olhando por uma das licenciaturas, mas eu tenho que perceber que estou olhando para uma mesma prática, uma mesma cultura, independentemente da face que eu esteja olhando. Ela é um filtro, uma lente, então ela filtra algumas coisas do que eu vou olhar pela formação que eu estou tendo, mas, ao mesmo tempo, ela como uma lente aumenta e da visibilidade a alguns aspectos que outras pessoas não podem ver pela formação que eu possuo.

Então, se eu penso no coletivo no tetraedro olhando cada um por uma dessas faces eu penso exatamente neste sentido da coletividade da escola, que estas práticas, estas culturas elas são do contexto escolar e elas devem ser olhadas por todos não apenas por algumas pessoas. Não o matemático ou de letras e ciências humanas, ciências da natureza olharem apenas a sua face, a sua lente. Existem outras e eu preciso olhar pelas outras, pelo menos considerar o que os outros estão olhando pelas outras lentes.

Também pensei que em vez de só olhar para dentro do tetraedro também tem que conseguir olhar pra fora do tetraedro. Então esta lente, esta face ela funciona também como um filme de como eu vou olhar o que acontece também fora da escola. Quem está dentro da escola tem que conseguir olhar para as práticas e para as culturas que estão na sociedade. Como que eu olho para o que está fora? Quem está na formação, no coletivo da escola (ou dos cursos de licenciatura), também olhará de uma maneira muito especial, porque ele tem uma lente que filtra algumas coisas e que aumenta outras no sentido da dar elementos que ele tem propriedade para falar sobre aquilo, porque ele está olhando para aquilo de uma maneira mais aprofundada pelo filtro que ele está olhando.

Ao mesmo tempo que eu penso nas individualidades, em cada face, este tetraedro me dá a ideia de que eu estou olhando também pelo coletivo. Eu tenho a minha face para olhar, mas eu sei que tem outras e que essas outras complementam e aí sim elas é que me dão a visão geral, não somente a minha face. Eliminar a fragmentação seria pensar em uma esfera, mas ainda temos es- 
tes cursos de matemática, ciências naturais, ciências humanas, linguagens separadamente.

Eu acho que nestes vértices, como a professora Maria Helena colocou eu posso colocar diversos elementos: afetividade, inclusão, tecnologias, avaliação. Posso colocar nestes vértices diversos elementos no sentido de que olhando para quem vai ser a base deste tetraedro seriam estes elementos e o que está fora da base seria como um fecho que dispara o meu olhar para as outras. $\mathrm{O}$ tetraedro faz a gente pensar em diversos aspectos, nos faz ter analogias com diversas coisas que a gente lê.

\section{Análise da Profa. Cristina Cerri.}

O Menezes é um provocador, não é? Ele faz a gente realmente sempre pensar em outros aspectos. Já trabalhamos juntos e ele faz a gente pensar a matemática de outra maneira e foi um processo muito interessante. Ele coloca esta questão, esta representação que é de um tetraedro. A primeira coisa que me incomodou e acho que já foi comentada aqui era o fato dele estar fechado.

Acho que a parte interna do tetraedro pode ser recheada de muitas coisas, culturas e práticas sociais interna e externamente como está aí colocado. Também gostaria de acrescentar - pegando o gancho do Miguel Ribeiro-, a parte do desenvolvimento da matemática como ciência. Pratica sociais também é pesquisa, também é este desenvolvimento que a humanidade busca, então para mim está dentro das práticas sociais e não apenas a prática com um sentido utilitário.

O SESI tem um desafio pela frente porque nós sofremos uma formação disciplinar, nós viemos de uma escola que tinha "caixinhas". Posteriormente a gente passou a refletir com a bendita pergunta: para que que eu estudo isto? Bom, a formação inicial que a gente lida na USP - e em qualquer lufar-, é natural o aluno perguntar: se eu vou ensinar Teorema de Thales, por que eu preciso saber da geometria neo-euclidiana? Se eu vou trabalhar só com geometria plana, porque vou trabalhar também com outros modelos de geometria? Isto se aplica também a outros conteúdos.

Existem vários aspectos que a gente discute no curso de formação de professores e que eu acho que esta ligação que a gente tenta fazer com a matemática produzida pela humanidade como ciência e a matemática que a gente trabalha na formação, na escola básica. A gente também tem que valorizar esta matemática como ciência em desenvolvimento.

Eu não conheço a proposta de formação que vocês estão trabalhando, mas acho que nesta proposta tem que olhar este tetraedro com várias possibilidades de base, a base pode ser qualquer face, então desconstruir esta ideia de que existe uma base é importante. E a ideia de que essas áreas elas devem conversar com as outras, mas elas têm características próprias, como ciência. E aí muitos já comentaram as características da matemática como uma ciência em 
desenvolvimento. Isto deve estar presente neste tetraedro e nestes cursos que vocês estão construindo aqui no SESI.

\section{Análise do Prof. Nilson José Machado.}

Eu acho a alegoria é mais de uma metáfora que o Menezes faz - metáfora como linguística-, e acho que não dá para esticar esta alegoria em pormenores, porque aí é explicar a piada, não funciona. A imagem que o Menezes traz é especialmente interessante por várias razões, mas uma razão é esta, quando a gente planifica, pensando nas áreas, no mapa, aí as áreas ficam aparentemente separadas. Mas quando você fecha o tetraedro, pensando no conteúdo, aí todas as faces se tocam.

E o tetraedro ainda tem uma coisa que amplifica a força da imagem que é a dualidade vértice $\mathrm{x}$ face. Se eu quiser chama os quatro vértices das quatro áreas eu tenho a mesma força porque os quatro vértices cada um está em contato com os outros três - e é o único poliedro que isto acontece.

Outra coisa é que "edro" a gente pensa como "face", mas etimologicamente significa "base de apoio". Só a médio prazo, ao longo da história é que a base de apoio é uma face. E é a coisa mais forte que já foi dito aqui, ou seja, eu posso apoiar em qualquer uma das faces e isto é irrelevante no caso do tetraedro. Se fosse um prisma já não valia.

Eu acho que por isto esta imagem é especialmente interessante, mas há uma particularidade no tetraedro que pode ser um delírio meu, mas quero explorar esta alegoria da maneira mais ampla possível, porque acho que ela sintetiza bem a força das quatro áreas e de não querer dispensar nenhuma.

Para finalizar, eu gostaria de lembrar do Nicolau De Cusa, um filósofo do renascimento, conselheiro do Papa e adorava matemática, ele possui um livro de meados dos anos 1400 que se chama "A Douta Ignorância", um livro que elabora uma imagem que tem a ver com o tetraedro. Ele diz que tudo que eu sei vou colocar dentro das minhas mãos, portanto a superfície da minha mão é o contato com o que eu não sei. Portando, quem sabe pouco não sabe que não sabe. Quanto mais eu sei mais aumenta a interface com o que eu não sei, ou seja, quanto mais eu sei mais eu sei que não sei. Este saber que não sabe é o que se define como a Douta Ignorância.

E o que tem isto a ver com o tetraedro? Tudo, pelo seguinte: se a superfície da minha mão é o contato com o que eu não sei, para um dado volume de conhecimento, qual é a superfície mínima para poder manter o conhecimento aí dentro? Não é uma esfera que seria uma boa receita, é o tetraedro, para separar o que sei do que eu não sei. Por quê? Porque se eu procurar para um dado volume qual é o poliedro regular que tem não área mínima, mas área máxima é o tetraedro. Simbolicamente, sem explicar metáfora, isto é muito forte porque ele é que me põe mais em contato com o que eu não sei e torna a minha ignorância douta. 
Naquela lista de perguntas da primeira parte acabou o tempo e eu não falei de uma, que era "como trabalhar com projeto considerando a matemática como uma área do conhecimento?". O trabalho com projeto ele significa essencialmente um exercício de articulação entre o interesse pessoal e o interesse coletivo, quem participa de um projeto tem meta junto com os outros. Em um projeto não pode haver coação, você participa junto com os outros. Agora, você também pode fazer um projeto estritamente dentro da matemática, um projeto estritamente científico. Ultimamente tem sido muito valorizado o trabalho com projetos, resolução de problemas, mas as vezes a gente percebe que a questão da fragmentação permanece, vira um projeto extremamente específico, coisa de especialista, e é isto que a gente está tentando combater. Mesmo que a gente não vá para o outro extremo do Antonio Miguel, de acabar com a disciplina, é fundamental colocar as disciplinas para conversar e isto pode ser feito ou não em um trabalho com projeto.

\section{Análise do Prof. Antônio Miguel.}

Quando você coloca a questão do conhecimento e eu caracterizei o indisciplinar não como algo que destrói. A desconstrução não é a destruição, como eu poderia sugerir. E nem o indisciplinar significa o anárquico ou o sem regras, ao contrário, você trabalhar com Wittgenstein sem falar de regras é absurdo. Então eu acho que o importante a entender, quando a gente fala que esta visão é pós-epistemológica, não é porque ela é contra o conhecimento ou não. É que ela vai pregar o seguinte, que não existe a possibilidade de você falar do conhecimento fora de um jogo de linguagem. O conhecimento não preexiste na linguagem ou ao jogo de linguagem; e nem o pensamento preexiste.

Todo pensamento só pode ser efetivado a partir de um jogo de linguagem. Se não existisse uma linguagem, algo que é organizado socialmente, nós não poderíamos pensar, memorizar e fazer absolutamente nada. No texto quando eu tento localizar que só existe um saber fazer como uma linguagem ou um jogo de linguagem em uma forma de vida este trio não pode ser dissociado. Então é tirar a questão do caráter absoluto do conhecimento como se ele tivesse significado da mesma maneira em todos os contextos onde ele é mobilizado. Por exemplo, na matemática se você pega o número do CEP de uma carta, pega o número que aparece em um código de barras, e um número natural, o que existe? Se eu aprender muito bem o conjunto dos números naturais eu vou entender este jogo de linguagens? Não. Se eu entender este e os números naturais eu vou entender o CEP? Não. Não existe esta coisa da generalização e da aplicação, é isto que torna incompreensível muitas vezes o que a gente está falando.

$\mathrm{Na}$ verdade, não é que o conhecimento é relativo no sentido do absolutismo ou relativismo, mas o conhecimento só pode significar o que ele significa no jogo de linguagem do qual ele faz parte. Portando este número não é um nú- 
mero no sentido matemático do número natural, ele é um número cujo significado só pode ser dado se eu souber as regras de linguagem que orientam a produção dos códigos de barra nas práticas de controle de estoque de mercadorias e na forma de vida do comércio.

Nesse sentido não existe este caráter absoluto do conhecimento, o indisciplinar significa exatamente você dar atenção para estes deslocamentos de uma coisa que é aparentemente igual, mas quando eu desloco para os diferentes contextos de atividades, nas formas de vida onde isto fará sentido, isto significa várias coisas diferentes. Dando outro exemplo, eu não posso falar no algoritmo da divisão, a criança vai aprender a dividir, se ela aprender a dividir ela vai saber dividir todas as formas de vida onde práticas de divisão são realizadas? Como é que se divide herança no contexto jurídico? A gente tem que estar atento às regras do jogo, neste sentido que os percursos indisciplinares na verdade significam uma visão pós-epistemológica não no sentido de descartar o conhecimento, mas de mostrar a relatividade do conhecimento nestes diferentes percursos que ele faz por diferentes formas e vida.

Quando vocês trazem as práticas culturais para o centro da problematização pedagógica é exatamente isto que a gente está querendo evidenciar. É não querer interpor a esta problematização a visão disciplinar como se nós aplicássemos a visão disciplinar para poder entender o modo como as coisas se passam nas diferentes formas de vida. Neste percurso dos estágios, por exemplo, uma das práticas que os alunos problematizaram foi a construção de vitrais, havia uma fábrica em Vinhedo de construção de vitrais, os alunos todos tinham suas formações específicas, um vinha das ciências sociais, outro da filosofia... significa se eu não sei geometria euclidiana eu não vou saber problematizar? Não. Então eles se colocavam em um percurso de investigação interessante, nem eu sabia nem eles. A formação disciplinar que cada um tinha era insuficiente para tentar levar uma problematização junto aos alunos da prática de construção de vitrais. Então nós fomos obrigados a investigar, a aprender para tentar fazer isto com os alunos.

O deslocamento indisciplinar nos desaloja das nossas visões e desconstrói a ideia de que o conhecimento no nosso modo como ele é mobilizado nos diferentes campos da atividade humana, ele é uma aplicação do modo verbal de aprender na escola. Nesse sentido, quando eu falo em prática, para evitar qualquer tipo de pragmatismo é exatamente isto que eu estou querendo dizer, são ações corporais regradas que nós fazemos e que mobilizam saberes, afetos, relações de poder, resistência, como foi o exemplo que eu dei com a prática cultural do algoritmo dos cálculos por escrito. No trânsito, tudo isto é mobilizado, as práticas enfrentam resistência, enfrentam relação de poder, o construto "prática" para mim não tem a ver com pragmatismo, ela destrói aquela ideia cognitivista que nós temos do conhecimento.

Voltando agora ao modelo do tetraedro, você sabia que eu seria um crítico dele, né? Eu não conheço profundamente a proposta, mas quando o 
Adilson me falou eu entendi que eram quatro cursos de licenciatura e aí o Menezes me apresentou o modelo tetraédrico e na visão do gestor evidentemente ele tem uma percepção tetraédrica. Mas fiquei pensando que na verdade ele é um psendo tetraedra, porque se eu olhar para a pessoa que passa pelo curso, ela não fará os quatro cursos, ela fará um. Então ela navegará por uma das faces. Eu tenho uma licenciatura em ciências da natureza, outra licenciatura em Linguagens, etc. $\mathrm{O}$ aluno terá a vivencia de uma das faces do tetraedro, mas não poderá fazer as conexões que você fez.

Existia para mim também uma outra resistência, não no sentido de entender, mas pela minha trajetória de entender a virada linguística, o conhecimento não como algo autônomo, mas como sempre algo que está atrelado a uma linguagem - não necessariamente a linguagem escrita ou oral-, mas ao jogo de linguagem que é uma coisa que a gente prática, a gente tem que entrar, participar. Se eu quero aprender como fazer vitrais, eu tenho que entrar no jogo, participar da fabricação de vitrais, porque não é simplesmente eu transferir a construção geométrica do triângulo com régua e compasso para o vidro, além disso os vitrais fazem parte de uma forma de vida com muitas regras de comercialização, etc.

São essas regras do jogo que vão fazer com que eu devo obedecer a um caráter normativo do meu modo de fazer. É diferente da geometria euclidiana que também tem a sua gramática normativa - que são os postulados, os primeiros princípios-, e aí tudo o que Euclides faz não deixa de ser um jogo normativo de linguagem, na concepção de Wittgenstein a matemática aparece como um conjunto de jogos, ela não aparece mais para a gente de modo unitário. Cada jogo é um jogo, e aprender um jogo não me capacita a jogar o outro. É uma visão completamente diferente, é inadmissível para mim imaginar que haverá um curso de licenciatura de linguagens e a matemática aqui e a ciência da natureza lá.

É uma crítica, mas é uma crítica que está ligado ao meu modo, a minha trajetória. Portanto para mim tudo é jogo de linguagem, e jogo de linguagem é um jogo normativo, ele orienta as nossas ações. Para o Wittgenstein as regras não são prescritivas, ela orienta; para fazer a carta com aquele CEP chegar naquele endereço corretamente eu tenho que entender o significado, entender que aquele jogo divide o território nacional em certos números de regiões, sub-regiões, setores, etc. Quando eu entendo a regra do jogo eu consigo fazer com que a carta chegue inequivocamente no endereço certo.

O que me faz ter êxito nesta minha ação é o conhecimento das regras do jogo. O número do CEP é uma prática de orientação espacial, o GPS também é uma prática de orientação espacial. As crianças, quando você organiza uma prova não por conteúdos, mas por práticas é muito interessante que a criança possa errar a mesma prática definida em um contexto de atividades diferentes, isto mostra para a gente que não existe uma prática de orientação espaci- 
al. Nesse sentido o modelo fica para mim difícil não de entender, mas de aceitar tendo esta visão das linguagens como sendo a possibilidade do pensamento.

\section{Análise do Prof. Adilson Dalben:}

Bem, começamos a nos direcionar para o fechamento dos trabalhos desta manhã, longe de quere esgotar essa temática, aproveitando para agradecer pela presença, que em muito nos honra, do Professor Dario Fiorentini, peço a gentileza que explicite algumas das observações e analise que fez durante as apresentações aqui realizadas.

\section{Análise do Prof. Dario Fiorentini:}

Bom dia a todos. Foi muito bom ouvir e tomar conhecimento das diferentes concepções, perspectivas e compreensões acerca de uma possível reorganização dos cursos de licenciatura por áreas de conhecimento, tendo como desafio promover certa integração ou interação entre essas áreas. Acho que a Faculdade SESI-SP de Educação está com um projeto de formação de professores muito interessante e, ao ver esta diversidade de ideias e opiniões, eu penso que há possibilidade de construir e desenvolver um programa de formação de professores de licenciatura que possam tornar mais permeáveis as fronteiras e o diálogo entre essas áreas, projetando não apenas mudanças na formação inicial dos professores, mas também mudanças na reconfiguração curricular da prática de ensino, numa perspectiva realmente educativa, nas escolas.

O professor Menezes, ao questionar sobre a pertinência de tomar o tetraedro como metáfora que representa, em suas faces, cada uma das quatro áreas de Licenciatura da Faculdade SESI-SP de Educação (Ciências na Natureza, Linguagem, Ciências Humanas e Matemática), sendo seu núcleo constituído por cultura e práticas sociais, nos provocou a pensar sobre como concebemos a integração ou relação entre essas áreas e as práticas socioculturais.

Alguns fizeram uma leitura bastante positiva dessa metáfora. Miguel Ribeiro chamou atenção às possíveis e necessárias relações e conexões entre as faces as quais deveriam ser exploradas no processo formativo. Nilson Machado destacou o fato de que, no tetraedro, todas as faces se tocam entre si, isto é, possuem uma aresta de contato, cuja interação pode ser incrementada mediante trabalho com projetos. Outros questionaram a rigidez que a metáfora do tetraedro pode ensejar. Cristina Cerri e Ana Lúcia questionaram sua estrutura fechada e de pouca permeabilidade entre suas áreas. Antonio Miguel tenta problematizar a impossibilidade dessas áreas abrigarem e contemplarem as práticas sociais e culturais, pois essas práticas geralmente não são disciplinares enquanto as quatro grandes áreas estão fortemente alinhadas a uma tradição disciplinar. Aponta como alternativa uma perspectiva de educação indisciplinar a partir do estudo de práticas sociais e culturais. 
A riqueza dessa discussão me fez lembrar outra metáfora utilizada pelo filósofo educacional Andy Hargreaves para tentar representar e compreender as dinâmicas dos processos de mudança da cultura profissional e da estrutura organizacional de instituições educativas em contextos pós-modernos que acomodam muitos professores, formando em seu interior pequenas comunidades alinhadas às áreas disciplinares que pouco interagem entre si e têm dificuldade de chegar a consensos. Hargreaves (1998) ${ }^{1}$ encontrou na Biologia Molecular Celular a metáfora ou o modelo do mosaico fluído que é formado por uma bicamada que constitui a membrana plasmática da célula a qual é responsável por separar o meio externo e interno da célula, além de atuar selecionando quem entra e quem sai dela.

A imagem do mosaico fluído nos ajuda a projetar mudanças numa prática educativa e romper com a divisão ou isolamento dos professores em áreas disciplinares específicas, sem que se dissolva as disciplinas escolares ou as áreas de conhecimento constituídas historicamente. Qualquer esforço de integrar ou inter-relacionar os conhecimentos especializados e sistematizados dessas áreas é, na maioria dos casos, uma tarefa inócua e inglória, pois os conhecimentos dessas áreas não são, por construção, interdisciplinares. Mas podemos considerar que, num contexto de formação de professores, estas áreas e seus conhecimentos formam camadas importantes e fundamentais do mosaico fluído. A outra camada pode ser formada, utilizando a própria expressão de Menezes, pelas práticas sociais e culturais, cujos fenômenos ou problemas de estudo são geralmente complexos e não disciplinares, requerendo para sua compreensão uma abordagem (inter, multi ou trans) disciplinar, pois os conhecimentos mobilizados pelos praticantes, nesse contexto, são indissociáveis e situados em uma prática profissional, como diria a antropóloga Jean Lave.

Entretanto, para que uma determinada prática, ou um determinado fenômeno/problema social possa ser minimamente compreendido, há necessidade da colaboração e do excedente de visão dos especialistas das diferentes áreas disciplinares. É nesse momento que o isolamento e divisão dos professores em grupos pode se romper, pois os sujeitos da formação (professores e estudantes) atuam na interface entre essas duas camadas que compõe o mosaico fluído que é onde acontece a experiência autenticamente formativa e a aprendizagem. Ou seja, todo o professor (ou formador de professores da licenciatura) e todo o estudante (ou futuro professor, no caso da licenciatura) terá um duplo movimento em relação a essas duas camadas, um movimento disciplinar no âmbito de sua área de conhecimento, onde o conhecimento especializado para ensinar é fundamental, e outro movimento (inter, multi ou trans) disciplinar buscando compreender o conhecimento situado em diferentes práticas profissionais ou sociais. O que os estudantes, com a mediação e colaboração dos professores ou

\footnotetext{
${ }^{1}$ HARGREAVES, A. Os professores em tempos de mudança - O trabalho e a cultura dos professores da era pós-moderna. Portugal: Editora McGaw-Hill, 1998.
} 
formadores, puderem extrair dessas duas camadas representa uma aprendizagem relevante culturalmente e altamente formativa.

Hargreaves é um educador norte-americano que tem produzido vários estudos sobre as mudanças curriculares e os processos de formação docente e o impacto disso no contexto da pós-modernidade. Penso que a adoção do modelo do mosaico fluído, no contexto da formação inicial de professores, como é o caso do SESI, representa, portanto, uma possibilidade de desconstruir progressivamente uma prática formativa exclusivamente disciplinar que normalmente ocorre nos cursos de licenciatura e não está voltada às demandas da prática profissional por outra prática formativa em que, de um lado, seja privilegiado o estudo de conhecimentos especializados e requeridos para uma prática profissional do ensino tanto de uma determinada disciplina escolar como, de outro lado, seja oportunizado, por meio de projetos interdisciplinares, o estudo e a aprendizagem de conhecimentos situados em diferentes práticas ou problemas/fenômenos sociais e culturais do mundo em que vivem os alunos da escola, tais como tem proposto Antônio Miguel. Cito, a título de exemplos: o estudo do GPS; do código de barra; das contas de água e luz; de situações de compra, venda e financiamento a longo prazo; a organização geopolítica da cidade onde vivem, etc.

A opção por um estudo de projetos implica, inevitavelmente, um trânsito pelas diferentes áreas ou para além das próprias fronteiras dessas áreas de conhecimento, e envolve a formação de turmas e grupos constituídos por estudantes de todas as áreas ou licenciaturas. O Curso, portanto, deve prever disciplinas de desenvolvimento de projetos comuns a todas as licenciaturas e envolver, também, a participação e colaboração de todos os formadores que atuam nesses cursos de licenciatura. A aprendizagem, nestes projetos, não será exclusiva dos estudantes (futuros professores), mas também dos formadores de professores, os quais terão além de uma aprendizagem interdisciplinar de conhecimentos situados nas práticas sociais ou profissionais, também uma aprendizagem como formadores de professores em um contexto de interdisciplinaridade, podendo, inclusive, tomar essa prática formativa como objeto de pesquisa.

Penso que este é um processo lento e gradual de mudança da cultura profissional docente e da cultura escolar, que envolve ou pressupõe tanto uma formação diferenciada de professores quanto a mudança cultural das práticas curriculares da escola. Ou seja, ao mesmo tempo que preservamos a tradição disciplinar no ensino, começamos também a constituir uma prática não disciplinar ou interdisciplinar, isto é, uma nova cultura escolar não colonizadora da prática escolar que tem como norte apenas o conhecimento acadêmico ou sistematizado, mas prevê também a produção e sistematização de conhecimentos a partir de projetos de estudo de situações-problema do mundo real das crianças e dos jovens que frequentam a escola.

Geralmente esquecemos, ou não percebemos, que o conhecimento disciplinar que hoje utilizamos para promover a formação docente e o ensino nas 
escolas resulta de uma síntese de um longo e trabalhoso processo histórico de sistematização de conhecimentos que tiveram origem, em sua maioria, nas práticas sociais e culturais. Para que esse conhecimento sistematizado e descontextualizado, organizado em forma de disciplina, possa ser ensinado às novas gerações, passa por um processo inverso de recontextualização e colonização de modo a transformar esse conhecimento disciplinar em saber a ser ensinado e aprendido pelas novas gerações. Os livros didáticos e os formadores de professores cumprem em grande parte esse papel colonizador. Por trás desse processo, há a crença epistemológica de que as crianças e jovens, ao se apropriarem desses conhecimentos, se habilitam automaticamente a transferi-los ou aplicálos às diferentes práticas sociais e profissionais. Mas, atualmente, muitas pesquisas em Educação Matemática, sob a perspectiva sociocultural, mostram que essa transferência ou transposição de conhecimentos não acontece da forma como os professores acreditavam. Daí a importância de a escola e de a formação de professores abrir espaço para o estudo de situações-problema ou práticas sociais que demandam abordagens não disciplinares ou indisciplinares como Antônio Miguel tem colocado com propriedade. Isso implica romper com a racionalidade técnica que ainda domina não só a formação dos professores, mas também a própria prática de "ensinar e aprender" historicamente constituída nas escolas.

Para concluir, penso que o modelo do mosaico fluído, em um ambiente de colaboração e de investigação e estudo de situações-problema ou de práticas sociais e culturais, pode ser um caminho fértil para romper com a tradição dis ciplinar e de racionalidade técnica que ainda predomina nas práticas de formação de professores e nas práticas de ensinar e aprender nas escolas. É claro que os professores e os licenciandos que vivenciarem esta experiência terão um papel importante da sistematização e socialização dos conhecimentos a serem produzidos neste contexto. Entretanto, gostaria de deixar claro que essa socialização não consiste em produzir material didático para que outros formadores ou professores possam aplicá-los em suas práticas profissionais. Isso significaria reproduzir a racionalidade técnica e a colonização das práticas dos outros. Mas essas experiências formativas de aprendizagem podem ser narradas e discutidas analiticamente em forma de livros, vídeos e outros modos de divulgação na web. Seria outra forma de cultura profissional que pode ser utilizada e discutida tanto na formação inicial de professores quanto na formação em serviço de professores vinculada às suas práticas de ensinar e aprender nas escolas.

\section{Prof. Adilson Dalben}

Usando a metáfora trazida pelo professor Nilson, eu diria que se alguém aqui achar que está saindo com muito mais dúvida, isso ocorre porque a superfície-fronteira entre os conhecimentos que temos e que não temos está aumentando. Que bom! 
Certamente obtivemos aqui elementos que nos ajudarão na formação inicial e continuada de professores de matemática. Creio que os olhares de satisfação e dúvidas dos nossos alunos da pós-graduação, que aqui participaram como observadores, sejam um indicador de que isso ocorreu.

Para concluir, preciso registrar aqui, a satisfação que temos em contar com a presença dos alunos da pós-graduação. Se não fosse pela disponibilidade de vocês em de encarar esse curso aos sábados, com esforço, estudo e tudo o mais que vocês sabem, nada disto aconteceria.

Muito obrigado a todos. 


\section{SOBRE OS AUTORES}

\section{Adilson Dalben}

Licenciado em Matemática (1987) e em Pedagogia (1992), com especialização em Administração de empresas (1989). É mestre em Educação (em 2008, com a dissertação "Avaliação Institucional Participativa na Educação Básica: possibilidades, limitações e potencialidades" e doutor em Educação (em 2014, com a tese "Fatores associados à proficiência em leitura e matemática: uma aplicação do modelo linear hierárquico com dados longitudinais do projeto GERES", ambos pela Faculdade de Educação da Universidade Estadual de Campinas. Suas áreas de pesquisa, onde atua como formador, são: Formação Docente, Educação Matemática e as relações entre Avaliação Educacional, Qualidade Educacional e Eficácia Escolar. Tem experiência profissional na Educação Básica e no Ensino Superior nas áreas de Educação Matemática, Gestão e Avaliação Educacional. Foi coordenador do curso de Licenciatura em Matemática e dos cursos de pós-graduação Lato Sensu da Faculdade SESI-SP de Educação. É pesquisador colaborador no Laboratório de Observação e Estudos DescritivosLOED e no Grupo de formação e pesquisa sobre o Conhecimento Especializado do Professor que ensina Matemática, ambos da Faculdade de Educação da Unicamp.

\section{Ana Lúcia Manrique}

Possui graduação em Matemática pela Universidade de São Paulo (1987), mestrado em Ensino de Matemática (1994) e doutorado em Educação (Psicologia da Educação) (2003), ambos pela Pontifícia Universidade Católica de São Paulo e Pós-doutorado no Programa de Pós-graduação em Educação da PUC/RJ (Pós-Doc Júnior CNPq) (2008). É professora do Programa de Estudos PósGraduados em Educação Matemática da Pontifícia Universidade Católica de São Paulo. Atuou como pesquisadora no projeto aprovado no edital dos Institutos Nacionais de Ciência e Tecnologia do MCT/CNPq/FNDCT/CAPES/ FAPEMIG/FAPERJ/FAPESP intitulado por "Instituto Nacional de Eletrônica Orgânica (INEO)". Coordenou subprojeto da área de Ciências Exatas do PIBID-PUC/SP. Coordenou projeto aprovado no Observatório da Educação, edital 2010, "Desafios para a educação inclusiva: pensando a formação de professores sobre os processos de domínio da matemática nas séries iniciais da educação básica". Participou como pesquisadora do projeto aprovado no Observatório da Educação, Capes, edital 2012, intitulado "Rede Colaborativa de Práticas na formação de professores que ensinam matemática: múltiplos olhares, diálogos e contextos", projeto em rede com a UFSCar, UFABC e PUC-SP. Coordenou projeto aprovado no edital 44/2014 do Programa de Apoio à Formação de Profissionais no campo das Competências Socioemocionais, projeto em parceria entre PUC/SP e UFTM. Coordenou localmente projeto aprovado 
no edital 59/2014 no Programa Tecnologia Assistiva no Brasil e Estudos sobre Deficiência, projeto em rede entre UFRJ, PUC/SP e UNIVAP. Foi consultor na revisão do Projeto Pedagógico de Curso de licenciatura em Matemática da Faculdade SESI-SP de Educação. Pesquisa sobre os seguintes temas: Formação de professores que ensinam matemática, Formadores de professores, Saberes docente, Trabalho docente, Mapas conceituais, Cálculo Diferencial e Integral e Educação Inclusiva.

\section{Antonio Miguel}

Licenciado em Matemática pela Pontifícia Universidade Católica de Campinas (1976), Mestrado em Educação pela Universidade Estadual de Campinas (1984) e Doutorado em Educação pela Universidade Estadual de Campinas (1993). Desde 1982, professor assistente doutor junto ao Departamento de Ensino e Práticas Culturais da Faculdade de Educação da Universidade Estadual de Campinas (UNICAMP). Professor, pesquisador pleno e orientador em nível de mestrado e doutorado junto ao Programa de Pós-graduação em Educação da Faculdade de Educação da Unicamp e junto ao Programa de Pós-Graduação Multiunidades em Ensino de Ciências e Matemática da Unicamp (PECIM). No primeiro desses programas, orienta nas duas seguintes linhas de pesquisa: Educação em Ciências, Matemática e Tecnologias; Linguagem e Arte em Educação. No PECIM, orienta na linha de pesquisa História, Filosofia e Linguagem na construção do conhecimento em Ciências da natureza e Matemática e no seu ensino. Membro fundador do Círculo de Estudo, Memória e Pesquisa em Educação Matemática (CEMPEM), da Revista Zetetiké, do Grupo de Pesquisa HIFEM (História, Filosofia e Educação Matemática) e do Grupo Interinstitucional de Pesquisa PHALA (Educação, Linguagem e Práticas Culturais). Junto ao HIFEM, desenvolve e orienta pesquisas nos campos: história e filosofia da matemática; história e filosofia da educação matemática; história e filosofia na educação matemática. Junto ao PHALA, desenvolve e orienta pesquisas nos campos: Estudos de práticas culturais vistas como jogos de linguagem; Educação indisciplinar em diferentes campos de atividade humana, incluindo o escolar; Historiografia de práticas culturais educativas (escolares e extraescolares); Historiografia cultural da matemática vista como conjuntos autônomos e dinâmicos de jogos de linguagem orientados por propósitos sociais normativos; relações entre matemáticas e artes vistas respectivamente como jogos preponderantemente normativos ou alegóricos de linguagem.

\section{Cristina Cerri}

Cursou Licenciatura em Matemática pela Universidade de São Paulo (1980). Fez mestrado em Matemática pela Universidade de São Paulo (1985). Seu doutorado em Matemática foi tipo "sanduiche" pela Universidade de São Paulo e University of New Mexico (EUA) (1993), na área de Algebra de Operadores. Desde 1983 é docente da Universidade de São Paulo. Além da atuação na área 
específica tem trabalhado com formação inicial e continuada de professores. De maio de 2011 a maio de 2017 foi Diretora do CAEM - Centro de Aperfeiçoamento do Ensino de Matemática do IME-USP. Tem se dedicado a temas relacionados.

\section{Dario Fiorentini}

Possui graduação em Matemática pela Universidade de Passo Fundo (1977), mestrado em Matemática Aplicada pela Universidade Estadual de Campinas (1980), doutorado em Educação (Metodologia de Ensino) pela Universidade Estadual de Campinas (1994) e Estágios Pós-doutorais de curta duração nas Universidades de Lisboa e de Sevilla. Atualmente é pesquisador PQ do CNPq (nível 1D) e professor doutor da Universidade Estadual de Campinas, onde exerce atividades de pesquisa e de docência na graduação e na Pós-Graduação em Educação (mestrado/doutorado). Temas e linhas de pesquisa e de atuação docente: educação matemática, formação e desenvolvimento profissional de professores, saberes docentes e prática didático-pedagógica em matemática. Foi assessor de projetos de pesquisa e programas de formação docente no exterior (Guatemala e Portugal). Foi Professor Visitante na Universidade de Córdoba (Argentina) e na Universidade de Lisboa (Portugal). Desde 1996 é assessor científico da FAPESP. No triênio de 2007-2009 e no quadriênio de 2013-2016, foi membro do Comitê de Avaliação de Programas de Pós-Graduação da CAPES - Área de Educação. Foi coordenador do Programa de Pós-Graduação em Educação da Faculdade de Educação da Unicamp (junho/2010 - julho/2014) e Coordenador Geral de Pós-Graduação da FE/UNICAMP (2011-2014). Desde março de 2015 é Editor Científico da Revista Zetetiké. Atualmente, a partir de 2017, é membro do CA-Ed do CNPq.

\section{Luis Carlos de Menezes}

Bacharel em Física (Universidade de São Paulo -1967), Mestre em Física (Carnegie Mellon University -1971), Doutor em Física (Universitaet Regensburg 1974). Professor Sênior do Instituto de Física da Universidade de São Paulo. Membro do Conselho Estadual de Educação em São Paulo. Consultor da UNESCO para propostas curriculares. Membro do Conselho do Prêmio Jabuti de Literatura, junto à Câmara Brasileira do Livro. Assessor do Ministério da Educação para a elaboração da Base Nacional Curricular. Foi Coordenador Acadêmico da Faculdade SESI-SP de Educação. Principais focos de trabalho em educação, currículos para a educação básica, formação de professores e ensino de ciências

\section{Maria Helena Soares de Souza}

Licenciada em Matemática pela Faculdade de Filosofia, Letras e Ciências Humanas da USP (1968) e Doutora em Educação Currículo pela Pontifícia Universidade Católica de São Paulo (2007). Tem experiência na área de Matemáti- 
ca, com ênfase em Geometria, Jogos Pedagógicos em Matemática, Álgebra e Estatística. Autora de coleções de livros didáticos da Matemática para o Ensino Fundamental e Ensino Médio e de livros paradidáticos de Matemática Financeira, Estatística e Laboratório. Foi consultora na revisão do Projeto Pedagógico de Curso de licenciatura em Matemática e dos programas de especialização no ensino da Matemática da Faculdade SESI-SP de Educação.

\section{Nílson José Machado}

Iniciou a carreira docente na Universidade de São Paulo em 1972, no Instituto de Matemática e Estatística (IMEUSP); a partir de 1984, transferiu-se para a Faculdade de Educação (FEUSP). É graduado em Matemática pela Universidade de São Paulo, mestre em História e Filosofia da Educação pela Pontifícia Universidade Católica de São Paulo (1981), doutor em Filosofia da Educação pela Universidade de São Paulo (1989) e Livre-Docente na área de Epistemologia e Didática, na Faculdade de Educação da Universidade de São Paulo (1994). No biênio 1993-1994, foi Professor Visitante no Instituto de Estudos Avançados da Universidade de São Paulo, no Programa Educação para a Cidadania. Atualmente é professor titular da Faculdade de Educação da Universidade de São Paulo, na condição de Professor Sênior. Chefiou o Departamento de Metodologia do Ensino e Educação Comparada ao longo de quatro mandatos. Já orientou mais de 50 mestres e/ou doutores, além de supervisionar diversos pós-doutorados. Coordena o Grupo de Pesquisa GEED (Grupo de Estudos em Epistemologia e Didática), cadastrado no CNPq. Suas principais publicações estão nas interfaces entre a Matemática e a Linguagem, entre a Epistemologia e a Didática, e entre a Ética e a Educação. Além dos livros e artigos acadêmicos, publicou mais de duas dezenas de livros para crianças a partir de 5 anos. Realiza semanalmente da FEUSP dois seminários abertos ao público em geral: o SEED (Seminários de Estudos em Epistemologia e Didática, desde 1997) e o SEMA (Seminários de Ensino de Matemática, desde 2008). Foi consultor na revisão do Projeto Pedagógico de Curso de licenciatura em Matemática da Faculdade SESI-SP de Educação. Publica semanalmente microensaios em seu site pessoal (www.nilsonjosemachado.net), onde podem ser encontrados os cronogramas de atividades semanais do SEED e do SEMA.

\section{Miguel Ribeiro}

Possui graduação em Licenciatura em Matemática (ensino de) pela Universidade da Beira Interior, Portugal (2001); mestrado em Matemática pela Universidade de Coimbra, Portugal (2005); mestrado em Didática da Matemática pela Universidad de Huelva, Espanha (2008); e doutoramento em Didática da Matemática pela Universidad de Huelva (2010). Trabalhou na Universidade do Algarve (2001-2009/2010-2011) e na Escola Superior de Educação de Lisboa como professor convidado (2009) - Portugal; na UNESP - Rio Claro, em um Pós-Doutoramento e em um Pós-Doutoramento na Noruega (2015). Durante 
o período do doutoramento - 2008-2010 - (como visitante), ou como professor visitante trabalhou também na University of Oxford (Reino Unido); University of Michigan (USA); Universidade Autónoma de Barcelona e Universidade de Huelva (Espanha); Universidade Frederico II (Itália); Universidade Católica de Valparaíso e Universidade de los Lagos, Puerto Montt (Chile); Universidad de Zacatecas (México). Atualmente é professor da Faculdade de Educação da UNICAMP. Foi consultor na revisão do Projeto Pedagógico de Curso de licenciatura em Matemática da Faculdade SESI-SP de Educação. Tem experiência na área de Educação, com ênfase no âmbito da Educação Matemática, atuando principalmente nos seguintes temas: conhecimento interpretativo; conhecimento especializado do professor de/que ensina matemática; tarefas para os alunos e para a formação de professores; conexões; resolução e formulação de problemas. 

Esperamos que este livro contribua para o debate político e filosófico sobre a educação. Afirmamos que caso seja infringido qualquer direito autoral, imediatamente, retiraremos a obra da internet. Reafirmamos que é vedada a comercialização deste produto.

Formato $\quad 15,5 \times 23 \mathrm{~cm}$

$1^{a}$ Edição Outubro de 2019

Navegando Publicações

$$
\underset{\text { D }}{2}
$$

www.editoranavegando.com

editoranavegando@gmail.com

Uberlândia - MG

Brasil 


Todo o material presente neste livro foi produzido para um evento realizado na Faculdade SESI-SP de Educação (FASESP) em outubro de 2016 e que teve por objetivo discutir as implicações e olhar para a Matemática como uma área de conhecimento na Educação Básica, tal como é a área de Linguagens, Ciências Humanas e Ciências da Natureza, extrapolando assim, a percepção de um componente curricular.

Com os resultados dessa discussão, esperou minimamente levantar novas questões que podem orientar o aprimoramento da organização curricular não só da Educação Básica, mas também, senão principalmente, de cursos de Licenciatura.

Como pode ser percebido, na Educação Básica, é vigente a ideia de ter a Matemática como um componente curricular, mas nesse contexto é apresentada como uma área de conhecimento.

Enfim, há implicações nessa mudança de categoria curricular? Se sim, quais são elas? Se não, por quê? Independentemente da reposta afirmativa ou negativa a essa pergunta, a formação de professores de Matemática deve estar conectada aos elementos que fundamentam a essas perguntas. Por isso, a Matemática como uma das áreas de conhecimento na organização curricular da Educação Básica é o tema abordado nesse livro.

Adilson Dalben 